\title{
Aportes al conocimiento taxonómico del género Persea (Lauraceae) en Venezuela
}

\author{
Hernán Ferrer-Pereira ${ }^{1,2}$
}

Recibido: 26.04.2011; aceptado: 30.08.2012

\begin{abstract}
Contributions to taxonomical knowledge of the genus Persea (Lauraceae) in Venezuela). A taxonomical revision was carried out for species of Persea (Lauraceae) in Venezuela from vouchers deposited at Venezuelan and foreign herbaria. Twenty-four species, including one new species and two new varities, new registers to Venezuela, expansion of distribution, distribution maps, and updated key for species at north and south of Orinoco River are reported. Descriptions in natural language and an interactive key for identification were obtained using Delta Software.
\end{abstract}

Key words: morphology, Neotropics, phytogeography, South America, taxonomy

RESUMEN - (Aportes al conocimiento taxonómico del género Persea (Lauraceae) en Venezuela). A partir de la revisión taxonómica de exsicatas depositadas en herbarios nacionales y extranjeros, se exponen los aportes al conocimiento taxonómico del género Persea (Lauraceae) en Venezuela. Se reportan 24 especies, incluyendo una especie y dos variedades nuevas para la ciencia, nuevos reportes para el país, ampliaciones de distribución, mapas de distribución y una clave actualizada para la determinación de especies en Venezuela. Utilizando el paquete DELTA, se obtuvieron descripciones en lenguaje natural y una clave interactiva para la identificación de taxones.

Palabras clave: América del Sur, fitogeografía, morfología, Neotrópico, taxonomía

\section{Introducción}

La familia Lauraceae constituye un grupo vegetal de alta importancia ecológica y económica en el Neotrópico. Entre los representantes más importantes se cuentan el aguacate (Persea americana Mill.) por sus grandes frutos comestibles, el aguacatillo (Persea caerulea (Ruiz \& Pav.) Mez) ampliamente utilizado en medicina alternativa por sus propiedades sedantes, el palo de rosa (Aniba rosaeodora Ducke), del cual se extraen esencias especiales para perfumería (Roth \& Lindorf 2002).

El género Persea Mill. fue descrito por Miller (1754), y la especie tipo, Persea americana, fue descrita en la $8^{\circ}$ edición de Gardener's Dictionary (Miller 1768); desde entonces una gran número de especies en las regiones tropicales de Asia y América han sido descritas. La revisión más reciente de las especies de este género en el continente americano fue realizada por Kopp (1966), quien reconoció dos subgéneros con 81 especies. Ésta es la única revisión taxonómica de amplio espectro que se ha hecho para Persea; el resto de los estudios taxonómicos se han quedado en descripciones nuevas y sinopsis (van der Werff 1989a, 2002). Este género presenta amplia distribución en el continente americano desde la Florida hasta Argentina, con aproximadamente 90 especies, una especie en las Islas Canarias y aproximadamente 100 especies en Asia (Kopp 1966, van der Werff 2002). Los principales centros de diversidad identificados para este género se ubican en América Central y el norte de Suramérica (Heywood 1993, Madriñán 2004). Para la Flora de la Guayana Venezolana, van der Werff \& Rohwer (1999) publicaron una breve descripción del género señalando la presencia de 13 especies, y posteriormente fueron reportadas 20 especies y dos variedades de Persea para Venezuela (van der Werff 2008). Así como la mayoría de las especies de Lauraceae en Venezuela, los especímenes de Persea son árboles o arbustos que forman parte de los bosques pluviales, nublados montanos y andinos, en un rango altitudinal desde 0 hasta 4.000 msnm (Ferrer-Pereira 2009).

1. Fundación Instituto Botánico de Venezuela “Dr. Tobías Lasser”, Gerencia de Investigación y Desarrollo, Av. Salvador Allende, Jardín Botánico de Caracas, Plaza Venezuela, apartado postal 2156, 1010-A Caracas, Venezuela

2. Autor correspondiente: hferrerp@gmail.com 
Respecto a la historia taxonómica del género, Bernardi (1962) mantuvo la proposición de Mez (1889) para dividir a Persea en cuatro subgéneros según el número de lóculos de las anteras de cada serie estaminal: Hemipersea, Hexanthera, Heterandra y Eupersea. Kopp (1966) y Bernardi (1962) mencionaron que hay una demarcación muy aguda entre dos grupos definidos, considerados subgéneros, y denominados: Persea y Eriodaphne. El primero se reconoce por los tépalos iguales a subiguales, reflexos en la antesis y caducos durante la fructificación, glándulas estipitadas en la base del tercer verticilo estaminal y pistilo pubescente. Este subgénero incluye la especie tipo Persea americana y otras especies centroamericanas. El subgénero Eriodaphne está caracterizado por presentar tépalos fuertemente desiguales y persistentes en la fructificación, tépalos externos glabros en la cara adaxial, glándulas sésiles en la base de los filamentos del tercer verticilo y ovario glabro o pubescente. Este subgénero comprende más de 70 especies neotropicales. Además de esta división, Kopp (1966) propuso un agrupamiento en subgéneros y secciones basado en el tamaño de los tépalos internos respecto de los externos, su caducidad en fructificación y la pubescencia en el ovario, donde Eriodaphne fue subdividido en cuatro secciones: Mutisaea, Hexanthera, Aurataea y Eriodaphne.

Actualmente se pueden distinguir los agrupamientos en las especies de Persea a nivel de subgénero; sin embargo, las secciones definidas por Kopp (1966) pueden parecer obsoletas ya que algunas especies (tales como $P$. julianae van der Werff, una especie de Surinam, P. rigens C.K. Allen y $P$. areolatocostae (C.K. Allen) van der Werff reportadas para Venezuela) presentan caracteres de dos secciones, lo cual hace incierta su posición bajo esta propuesta taxonómica. van der Werff (1989b) consideró que estas especies forman parte de un grupo anómalo que debe ser investigado.

\section{Materiales y métodos}

Esta investigación fue llevada a cabo mediante revisiones directas sobre los pliegos y fotografías de los ejemplares de referencia (tipos) depositados en los principales herbarios venezolanos (VEN, MY, PORT, GUYN, MER, MERF, MERC, CORO, HERZU, TFAV, CAR, UCOB, HMBLUZ y UOJ) y extranjeros (MO, NY, F, US, K, B, G-DC). Además de ello, se consultó la literatura especializada en este grupo, así como las publicaciones originales. Se realizaron visitas al campo para obtener nuevas muestras y enriquecer aquellas existentes en el Herbario Nacional de Venezuela.

Selección de criterios para caracteres y estados relevantes en la discriminación de taxones - Los caracteres empleados para el estudio taxonómicos están basados en las observaciones de Kopp (1966) y van der Werff (1989a, b, 1999, 2002). Los caracteres taxonómicamente informativos referidos a morfología foliar se basaron en Hickey (1973) y los tipos de tricomas de acuerdo con Payne (1978). Las observaciones sobre la dirección y forma de los tricomas fueron similares a las reportadas por Nishida (1999) y se establecieron los estados: adpresos, ascendentes y erectos, para la dirección, y liso, ondulado y fuertemente ondulado (equivalente a rizado o "curly" según la autora) para expresar la forma de los tricomas. Para el carácter referido a la cobertura del indumento, se definieron cualitativamente cuatro estados en función del porcentaje visible de epidermis en el órgano evaluado, según Ferrer-Pereira et al. (2010). Los atributos sobre forma de las anteras, distribución del indumento en partes reproductivas y longitudes de las inflorescencias respecto de la hoja adyacente fueron categorizados a partir de las observaciones obtenidas en esta investigación. Para efectos de descripción, los verticilos estaminales se han abreviado como V1, V2, V3 y V4, siendo V1 la serie más externa y V4, el conjunto de estaminodios. Además, se ha separado las características de indumento como un aporte a la descripción. Se empleó la metodología descrita por Ferrer-Pereira et al. (2010) para la obtención de descripciones de taxones, claves dicotómicas y claves interactivas con el paquete de software DELTA. Los caracteres inherentes al indumento en cada especie fueron separados de las descripciones a fin de evitar la repetición y para que puedan ser empleados por su utilidad taxonómica.

Distribución de las especies y endemismos - Los datos obtenidos fueron introducidos en una base de datos. Los mapas de distribución fueron obtenidos a partir de la información de rótulos de herbario y cargados en el programa Quantum GIS v.05 sobre un mapa georreferenciado de Venezuela.

\section{Resultados}

Basado en los resultados, en Venezuela se encuentran 24 especies de Persea, incluyendo dos variedades nuevas para la ciencia. Durante la revisión se encontraron los pliegos Cuello et al. 1753, Cuello 
et al. 1763 y Cuello et al. 2472, señalados como Persea sp. A. vel aff. hexanthera L.E. Kopp, que podrían tratarse de nuevas especies; sin embargo, es necesario obtener colecciones en estado reproductivo.

Caracteres morfológicos - Según lo observado en campo y en exsicatas, las especies de Persea en Venezuela muestran variaciones en la longitud y forma de las inflorescencias y otros caracteres de sus frutos que llegan a ser propiamente específicas. La relación entre la longitud de la inflorescencia respecto a la hoja más próxima, u hoja adyacente, sirve como carácter taxonómico para discriminar entre taxones o grupos de taxones. En algunas especies como $P$. grandiflora L.E. Kopp, P. fastigiata L.E. Kopp y P. jenmani Mez, las inflorescencias pueden alcanzar el doble de la longitud de la hoja adyacente; mientras que en P. pseudofasciculata L.E. Kopp y P. fluviatilis van der Werff no sobrepasan el tercio basal. Otras especies presentan inflorescencias de apariencia corimbiforme, tales como P. subcordata (Ruiz \& Pav.) Nees, $P$. ferruginea Kunth y P. mutisii Kunth (figura 1). Es de hacer notar, que incluso cuando la planta sea completamente glabra en las partes vegetativas, siempre se encuentran tricomas en el exterior de las flores, como en $P$. povedae W.C. Burger y P. rigens. En el caso de esta última especie, las flores brotan en inflorescencias subterminales cortas que suelen prolongarse conforme ocurre la maduración del fruto, alcanzando hasta $30 \mathrm{~cm}$ de longitud.

Se pueden distinguir varias especies por el contorno de sus frutos que van desde oblados ( $P$. rigens, figura $2 \mathrm{C}$ ) hasta globosos ( $P$. ferruginea, figura 2I), la persistencia parcial ( $P$. caerulea, figura 2B) o total (P. mutisii, figura 2J) de los tépalos durante la fructificación y otras características del receptáculo, como el engrosamiento en frutos maduros (P. lemensis, figuras $2 \mathrm{H}, 3 \mathrm{D})$ o la presencia de lenticelas como en $P$. povedae (figura 2A). En pocos casos, los tépalos persistentes se tornan rígidos como en $P$. mutisii y $P$. ferruginea o se elongan en $P$. rigens.

A partir de los especímenes y los caracteres de la clasificación de Kopp (1966), y siguiendo el planteamiento de van der Werff (2002), se pueden identificar tres grupos y cuatro subgrupos:

(1) Especies con tépalos iguales a subiguales, caducos durante la fructificación y glándulas estipitadas en el tercer verticilo estaminal. Este grupo coincide con los atributos seleccionados para el subgénero Persea. Especie circunscrita: Persea americana.
(2) Especies con tépalos desiguales, persistentes y/o patentes durante la fructificación, glándulas sésiles, basales o subbasales, presentes en el tercer verticilo estaminal, lo cual coincide con el subgénero Eriodaphne.A este grupo pertenece la mayor cantidad de especies descritas por lo que puede subdividirse en:

(2.1) Especies con seis estambres fértiles (sección Hexanthera): P. meridensis, $P$. hexanthera, P. pseudofasciculata, P. fastigiata y P. fluviatilis. (2.2) Especies con nueve estambres fértiles, inflorescencias corimbiformes, tépalos endurecidos durante la fructificación, hojas coriáceas con pecíolos aplanados hata anchamente acanalados (sección Mutisaea): P. mutisii, P. ferruginea y P. ruizii.

(2.3) Especies con nueve estambres fértiles, ovario y/o estilo pubescentes (sección Aurataea): P. grandiflora, P. perseiphylla, P. croatii y P. maguirei.

(2.4) Especies con nueve estambres y ovario completamente glabro (sección Eriodaphne): P.jenmanii, P. caerulea, P. subcordata, P. lemensis, P. povedae, P. cuneata y $P$. croizatii.

(3) Especies con tépalos subiguales, patentes y persistentes durante la fructificación, glándulas basales o estipitadas en el tercer verticilo estaminal. Estas características son incongruentes con las definidas por las secciones de Kopp (1966) por lo cual van der Werff (2002) ha definido este grupo como anómalo y sin circunscripción taxonómica. En Venezuela, $P$. rigens, $P$. fendleri, $P$. bernardii y $P$. areolatocostae son los representantes de este grupo.

Nuevos reportes y ampliaciones de distribución - Los datos obtenidos durante la revisión fueron comparados con la lista más reciente (van der Werff 2008) y se obtuvieron los siguientes nuevos reportes de distribución geopolítica para las especies en estudio: a) P. caerulea en Falcón (Wingfield 5775-VEN, Wingfield et al. 7863, Ferrer et al. 714) y Nueva Esparta (Sugden 1138, Xena et al. 1197). Estos pliegos se encuentran depositados en VEN.

b) P. ferruginea en Lara (Riina et al. 726, 895, 915 : depositados en VEN; Ruiz-Terán \& López Figueiras 903, 940: depositados en MERF; Duno \& Riina 1473, Dorr et al. 5494: depositados en PORT) y Táchira $(J$. Cavelier 2: depositado en Coro).

c) P. mutisii en Apure (Manara s.n.: depositado en VEN), Barinas (Dorr et al. 5750: depositado en PORT) y Sucre (Meier \& Bronner 3563, 3564: depositados en VEN). 
d) P. rigens en Monagas (Steyermark 61989: depositado en VEN), Lara (Steyermark et al. 110164: depositado en VEN), Portuguesa (Cuello et al. 1770: depositado en VEN) y Trujillo (Niño et al. 624: depositado en PORT).

e) P. subcordata en Táchira (Steyermark 57109: depositado en VEN) y Trujillo (Bono 6040, Ruíz-Terán \& López-Palacios 7647: depositados en VEN y MERF, respectivamente).

Nuevos registros para Venezuela - Además de esto, se contrastaron las listas de especies encontrándose nuevos reportes de especies para Venezuela:

a) Persea hexanthera L.E. Kopp: $H$. van der Werff 3683 (VEN, CORO), R. Wingfield \& B. Rollet 8261
(CORO), R. Wingfield 12943, 13693, 13694 (VEN, CORO), A.L. Bernardi 5728 (MER), A. Cardozo \& X. Bastardo 2175 (MY).

b) Persea povedae W.C. Burger: Ara 11 (MER), Ruíz-Terán 1421 (PORT, HERZU), Smith V3260 (UCOB), V3261 (VEN).

c) P. ruizii Macbr.: Kelly \& Lughadha 8910 (VEN).

Novedades taxonómicas - Se describen una especie y dos variedades nuevas para la ciencia: $P$. lemensis, $P$. rigens var. oblaticarpa y $P$. fastigiata var. bilocularis.

Se encontraron muestras de Persea depositadas en el herbario PORT que fueron identificadas como

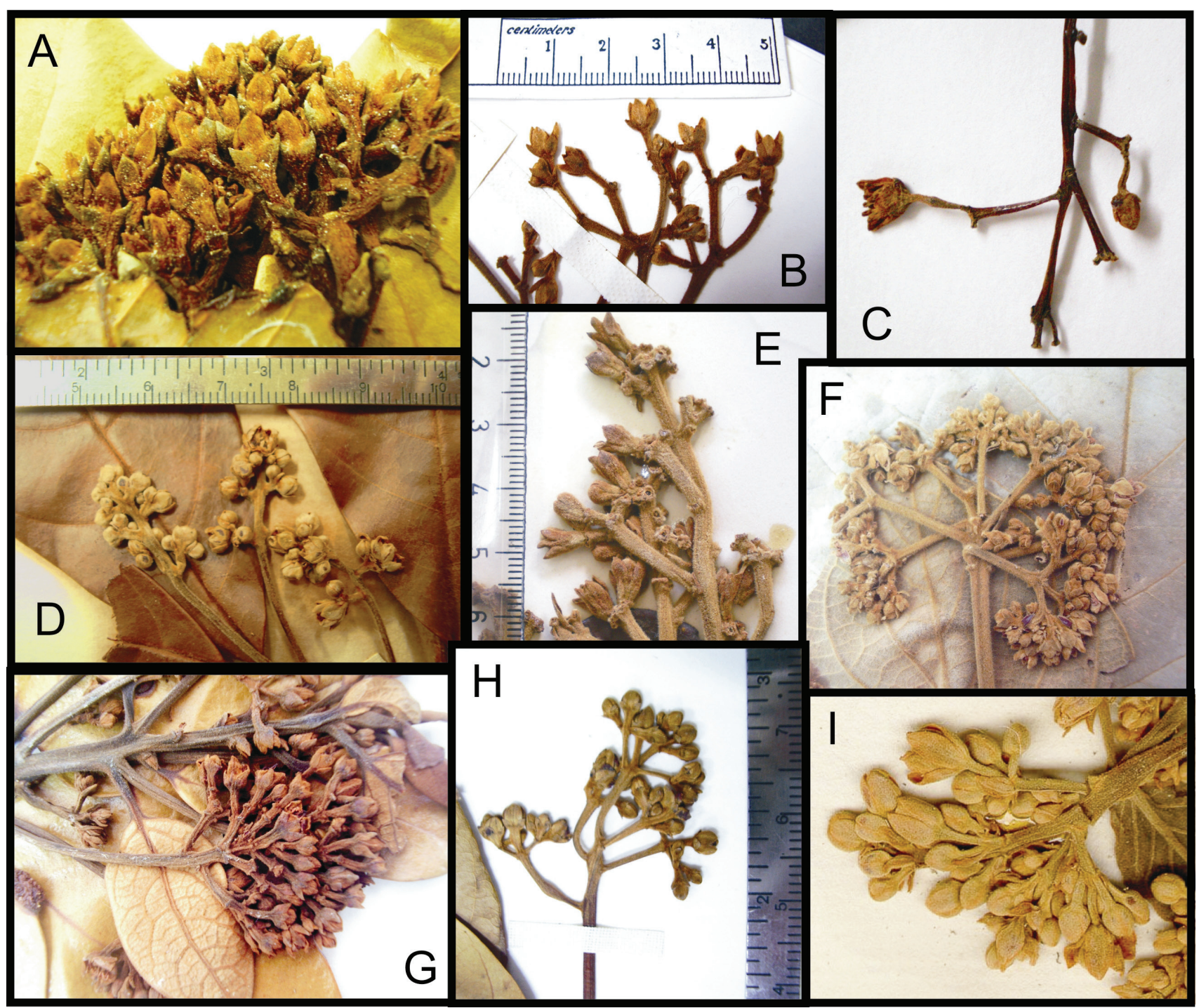

Figura 1. Variación en la forma y tamaño de las flores de muestras herborizadas. A. Persea mutisii. B. P. meridensis. C. P. lemensis. D. P. fluviatilis. E. P. bernardii. F. P. subcordata. G. P. ferruginea. H. P. caerulea. I. P. americana.

Figure 1. Shape and size variation observed in flowers from herbaria sheets. A. Persea mutisii. B. P. meridensis. C. P. lemensis. D. P. fluviatilis. E. P. bernardii. F. P. subcordata. G. P. ferruginea. H. P. caerulea. I. P. americana. 
$P$. aff. mutisii y $P$. aff. peruviana; sin embargo, las muestras son estériles y sus características no coinciden completamente con una especie actualmente conocida. En este mismo herbario se encontraron muestras estériles con etiquetas de determinación del Dr. Henk van der Werff en las que se especifica que el material puede representar especies nuevas; pero no se ha hecho publicación de estos ejemplares aún. A partir de las visitas al campo realizadas durante esta investigación, se colectaron muestras de $P$. meridensis y $P$. subcordata en fruto, así como de otras especies señaladas en la figura 3.

Ámbitos de distribución de las especies en Venezuela Con la matriz de exsicatas depurada, se realizó un análisis de distribución de las especies y se tomó en cuenta su distribución por estados geopolíticos y altitudinal. Los estados con mayores colecciones de especies del género Persea son Mérida $(25,43 \%)$, Trujillo (14,81\%) y Amazonas (12,10\%). Respecto de la distribución altitudinal, es posible afirmar que la mayoría de las especies de Persea presentes en Venezuela $(76 \%)$ se encuentran por encima de los $1.000 \mathrm{msnm}$, mientras que un $8 \%$ ha sido colectado por debajo de los $500 \mathrm{msnm}$. Persea ferruginea y $P$. mutisii son las especies que se han colectado por encima de los $3.000 \mathrm{msnm}$. Según los datos encontrados, $P$. meridensis, $P$. fendleri, $P$. croatii, P. croizatii, P. maguirei y $P$. fluviatilis son especies endémicas para Venezuela (figuras 4, 5, 6, 7).

Cabe destacar que se ha identificado un patrón de distribución de las especies restringido por la formación Los Llanos y el río Orinoco como barrera natural. La mayoría de las especies reportadas para el norte del país (Cordillera de la Costa y Cordillera de los Andes) no se encuentra de forma natural al sur del Orinoco, y viceversa, con las especies del sur. Tan sólo Persea americana, se encuentra a ambos lados del río debido a su aprovechamiento local y consumo.

Persea (Clus.) Mill., Gard. Dict. Abr. ed. 4. 1754.

Árboles o arbustos; ramas con sección transversal terete o angular, glabras o con tricomas lisos hasta fuertemente ondulados, blanquecinos, amarillentos, parduzcos o ferrugíneos, adpresos hasta erectos, con cobertura muy laxa a densa; yemas apicales cortas o alargadas, con indumento igual que las ramas o glabras. Hojas distribuidas a lo largo de las ramas o agrupadas en las puntas;

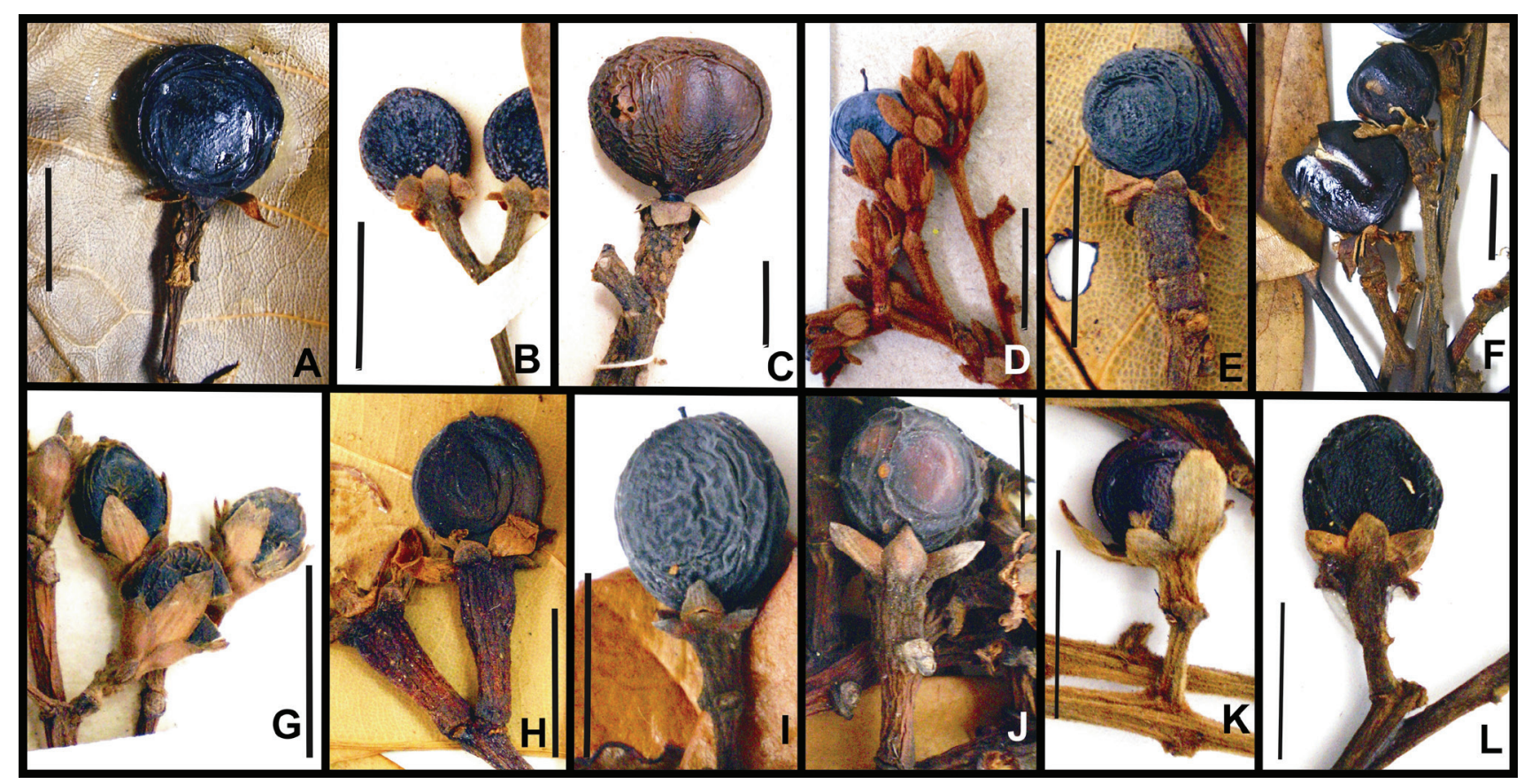

Figura 2. Variación en la forma y tamaño de los frutos de muestras herborizadas. A. Persea povedae. B. P. caerulea. C. P. rigens var. oblaticarpa. D. P. jenmani. E. P. fastigiata. F. P. pseudofasciculata. G. P. cuneata. H. P. lemensis. I. P. ferruginea. J. P. mutisii. K. P. grandiflora. L. P. hexanthera. $($ Barra $=1 \mathrm{~cm})$

Figure 2. Shape and size variation observed in fruits from herbaria sheets. A. Persea povedae. B. P. caerulea. C. P. rigens var. oblaticarpa. D. P. jenmani. E. P. fastigiata. F. P. pseudofasciculata. G. P. cuneata. H. P. lemensis. I. P. ferruginea. J. P. mutisii. K. P. grandiflora. L. $P$. hexanthera. $($ Bar $=1 \mathrm{~cm})$ 
pecíolos 0,55-4,50 × 0,10-0,58 cm, acanalados, aplanados o canaliculados, glabros o con tricomas lisos a fuertemente ondulados, blanquecinos, amarillentos, parduzcos o ferrugíneos, adpresos a erectos, con cobertura muy laxa a densa; láminas foliares ovadas, elípticas u oblongas, 3,0-34,0 × 2,1-13,4 cm, glabras o pubescentes en la cara abaxial; ápice agudo hasta obtuso, redondeado, acuminado o atenuado, base obtusa, decurrente, desigual o cuneada, margen entero hasta revoluto en toda su extensión; nervio medio plano o hundido en la haz, glabro hasta densamente pubescente; venación broquidódroma a eucamptódroma, 5-12 pares de venas secundarias, divergentes en ángulo agudo hasta obtuso, rectas o curvas, generalmente ramificadas antes de alcanzar el margen, libres o anastomosadas, cerrándose en ángulo agudo hasta obtuso con la vena superior adyacente, o por arcos secundarios formados por venas de $3^{\mathrm{o}}$ y $4^{\mathrm{o}}$ orden, con patrón reticulado ortogonal o aleatorio, o patrón percurrente recto, recurvo o convexo; venación marginal fimbriada o formando lazos cerrados, areolas perfectamente desarrolladas, de forma angular o redondeada, con o sin venillas simples o ramificadas dentro de la areola, o imperfectamente desarrolladas o poco visibles. Inflorescencias de apariencia corimbiforme o en panículas subterminales y axilares, hasta $26,6 \mathrm{~cm}$ long., alcanzando desde 3 veces hasta menos de $1 / 4$ de la longitud de las hojas adyacentes. Flores 3,5-10,0 mm long., pedicelos 1,5-10,0 mm long. Tépalos iguales a subiguales entre sí o fuertemente desiguales, patentes a erectos, con tricomas lisos hasta fuertemente ondulados, ascendentes a erectos, en ambas caras de los tépalos, o ausente en la cara adaxial de los tépalos externos. Estambres fértiles 6 a 9; anteras de V1 y V2 ovadas, trapezoidales u oblongas, 2 o 4 lóculos, con dehiscencia introrsa, glabras o pubescentes, filamentos hasta $2,7 \mathrm{~mm}$ long., glabros o pubescentes; anteras del V3 ovadas a oblongas o reducidas a estaminodios, con dehiscencia extrorsa a extrorsa-latrorsa, glabras o pubescentes, filamentos hasta $3,1 \mathrm{~mm}$ long., glabros o pubescentes, acompañados de un par de glándulas cordadas, ovadas o redondeadas, sésiles o estipitadas, adnadas en la parte basal o a $1 / 4$ de la longitud del filamento; estaminodios 3 , sagitados, glabros o pubescentes; ovario ovado, esférico o elipsoidal, glabro o cubierto por tricomas lisos a fuertemente ondulados, blanquecinos, amarillentos, parduzcos o ferrugíneos, adpresos hasta ascendentes, con cobertura muy laxa a medianamente densa, estilo tanto o ligeramente más largo que el ovario, glabro o pubescente. Frutos globosos, deprimidos-globosos, elípticos, piriformes a obovados, $0,9-25,0 \times 0,5-15,0 \mathrm{~cm}$, a menudo los tépalos y estambres son persistentes durante la fructificación, en pocas especies son completamente o parcialmente caducos.

Clave para las especies de Persea presentes en Venezuela

1. Cara abaxial de las hojas con tricomas que cubren más del $50 \%$ de la superficie

2. Tricomas de la cara abaxial erectos, generalmente ondulados o fuertemente ondulados, ovario glabro

3. Inflorescencias corimbiformes; pecíolos aplanados o anchamente acanalados, más 3,5 mm de ancho; las venas de $3^{\circ}$ y $4^{\circ}$ forman un patrón reticulado en la cara abaxial de las hojas

4. Pubescencia formada por tricomas parduzcos a ferrugíneos; venas de $3^{\circ}$ y $4^{\circ}$ orden rominentes en la cara abaxial, visibles a pesar del cobertura del indumento; fruto $1 \mathrm{~cm}$ diám. 10. P. ferruginea

4. Pubescencia formada por tricomas amarillentos; venas de $3^{\circ}$ y $4^{\circ}$ orden inmersas en la cara abaxial cubiertas por el indumento; fruto más de 1,0 cm diám. 24. P. subcordata

3. Inflorescencias en racimos o panículas; pecíolos teretes o canaliculados de hasta 3,5 $\mathrm{mm}$ de ancho; patrón reticulado, nunca prominente en la cara abaxial de las hojas

5. Tricomas ferrugíneos a pardo oscuro, con cobertura densa; inflorescencias más largas que las hojas 14. P. jenmanii

5. Tricomas amarillentos a pardo claro, de cobertura medianamente densa en la cara abaxial; inflorescencias tanto o más cortas que las hojas

6. Tépalos externos subiguales a los internos, pubescentes en ambas caras 3. P. bernardii 6. Tépalos externos tan largos como la mitad de los internos, pubescentes sólo en la cara adaxial 
2. Tricomas de la cara abaxial adpresos, siempre lisos; ovario pubescente

7. Hojas ovadas, raramente elípticas; inflorescencias siempre más largas que las hojas; flores más de $8 \mathrm{~mm}$ long. 12. P. grandiflora

7. Hojas elípticas; inflorescencias tan largas o más cortas que las hojas; flores hasta $8 \mathrm{~mm}$ long.

8. Láminas de ápice redondeado; inflorescencias más cortas que las hojas, paucifloras 16. P. maguirei

8. Laminas de ápice agudo a obtuso, nunca redondeado; inflorescencias más largas que las hojas, multifloras

9. Pubescencia en la cara abaxial e inflorescencias de color cobrizo, densa; flores 4-5 mm long 19. P. perseiphylla

9. Pubescencia no cobriza, más bien pardo oscuro, medianamente densa; se distingue la epidermis en algunas zonas; flores 6-8 $\mathrm{mm}$ long.

5. P. croatii

1. Cara abaxial de las hojas glabras o con tricomas que cubren menos del $50 \%$ de la superficie

10. Estambres fértiles 6

11. Inflorescencias siempre más cortas que las hojas

12. Flores 3,8-4,5 mm long.; ramas con sección transversal angular, huecas; pedicelos ensanchados en el fruto 11.P. fluviatilis

12. Flores $2,85 \mathrm{~mm}$ long. o menos; ramas con sección transversal angular a terete, sólidas; pedicelos nunca o muy poco ensanchados en el fruto 21.P.pseudofasciculata

11. Inflorescencias tanto o más largas que las hojas

13. Flores más $6 \mathrm{~mm}$ long. 13. P. hexanthera

13. Flores menos $5 \mathrm{~mm}$ long.

14. Hojas oblanceoladas, raramente elípticas; margen revoluto, generalmente glabras o pubescentes; 8-13 pares de venas secundarias; creciendo en bosques húmedos de Bolívar y Amazonas 8. P. fastigiata

14. Hojas anchamente elípticas hasta oblongas; margen plano, densamente pubescentes; 6-8 pares de venas secundarias; creciendo en bosques nublados andinos 17.P. meridensis

10. Estambres fértiles 9

15. Tépalos externos siempre más cortos que $3 / 4$ de la longitud de los internos, cara adaxial glabra

16. Hojas, ramas y pecíolos completamente glabros, raras veces con pocos tricomas erectos con cobertura laxa

17. Pedicelos engrosados en el fruto; tépalos persistentes, poco lignificados

18. Hojas obovadas, ápice redondeado, 10-13 pares de venas secundarias; pedicelo con lenticelas durante la fructificación

20. P. povedae

18. Hojas elípticas u ovadas, ápice obtuso, 7-8 pares de venas secundarias; pedicelo sin lenticelas durante la fructificación .

15. P. lemensis

17. Pedicelos no engrosados en el fruto; tépalos persistentes, más o menos lignificados

19. Inflorescencias corimbiformes; tépalos patentes en fruto; pecíolos aplanados, muy anchos en la base; anteras con cuatro lóculos

18. P. mutisii

19 Inflorescencias en panículas; tépalos erectos hacia el fruto: pecíolos teretes; anteras con dos lóculos 7. P. cuneata

16. Hojas, ramas y pecíolos siempre con tricomas adpresos, lisos

20. Hojas muy anchamente ovadas, raramente elípticas, 9-12 pares de venas secundarias; tépalos internos hasta 3,5 veces más largos de que los externos, parcialmente caducos durante la fructificación

20. Hojas elípticas, con 6-8 pares de venas secundarias; tépalos internos hasta dos veces más largos que los externos, enteros y persistentes durante la fructificación

21. Tricomas cubriendo menos del $30 \%$ de la superficie adaxial de las hojas; anteras de V3 con 4 lóculos funcionales 6. P. croizatii

21 . Tricomas cubriendo más del $50 \%$ de la superficie adaxial de las hojas; anteras de V3 únicamente con lóculos inferiores funcionales 8. P. fastigiata 
15. Tépalos iguales o ligeramente más cortos que los internos, cara adaxial pubescente

22. Frutos piriformes, más de $5 \mathrm{~cm}$ de largo; tépalos completamente caducos durante la fructificación; pedicelos en flor de hasta $10 \mathrm{~mm}$ long.

22. Frutos globosos, deprimidos u oblados, de hasta $3 \mathrm{~cm}$ de largo; tépalos persistentes durante la fructificación; pedicelos en flor no mayores de $6 \mathrm{~mm}$ long.

23. Hojas coriáceas, congestionadas en los extremos de las ramas, glaucas en la cara abaxial; flores densamente tomentosas, de color blanco-ceniciento; frutos oblados, brevemente estipitados

2. Hojas cartáceas, distribuidas a lo largo de las ramas, alternas, nunca glaucas; flores con tricomas amarillentos, blanquecinos a translúcidos; flores globosos o deprimido-globosos

24. Flores hasta $5 \mathrm{~mm}$ long.; glándulas sésiles, subbasales, que alcanzan hasta la mitad del filamento en longitud; distribución restringida al sur del Orinoco, hasta $700 \mathrm{msnm}$

2. P. areolatocostae

24. Flores 2,5-3 mm long.; glándulas estipitadas cerca de la base de los estambres del tercer verticilo; común en la Cordillera de la Costa, por encima de $1.200 \mathrm{msnm}$ 9. P. fendleri

En la tabla 1 se reportan los taxones encontrados en Venezuela, describiendo su distribución por estados y el rango altitudinal registrado de acuerdo con la información de herbario.

Tabla 1. Lista de taxones pertenecientes al género Persea reportados para Venezuela, indicando datos de distribución. AN: Anzoátegui, AM: Amazonas, AR: Aragua, BA: Barinas, BO: Bolívar, CA: Carabobo, CO: Cojedes, DC: Distrito Capital, FA: Falcón, GU: Guárico, LA: Lara, ME: Mérida, MI: Miranda, MO: Monagas, NE: Nueva Esparta, PO: Portuguesa, SU: Sucre, TA: Táchira, TR: Trujillo, YA: Yaracuy, ZU: Zulia.

Table 1. Taxa list of Persea reported in Venezuela, showing distribution data. AN: Anzoátegui, AM: Amazonas, AR: Aragua, BA: Barinas, BO: Bolívar, CA: Carabobo, CO: Cojedes, DC: Distrito Capital, FA: Falcón, GU: Guárico, LA: Lara, ME: Mérida, MI: Miranda, MO: Monagas, NE: Nueva Esparta, PO: Portuguesa, SU: Sucre, TA: Táchira, TR: Trujillo, YA: Yaracuy, ZU: Zulia.

Taxones Distribución por Estados

1. Persea americana Mill.

2. P. areolatocostae (C.K. Allen) van der Werff

3. P. bernardi L.E. Kopp

4. P. caerulea (Ruiz \& Pavón) Mez

5. $P$. croatii van der Werff

6. P. croizatii van der Werff

7. P. cuneata Meisn.

8. P. fastigiata L.E. Kopp

8.1. P. fastigiata var. fastigiata L.E. Kopp

8.2. P. fastigiata var. sericea L.E. Kopp

8.3. P. fastigiata var. bilocularis H. Ferrer

9. P. fendleri van der Werff

10. P. ferruginea Kunth

11. P. fluviatilis van der Werff

12. P. grandiflora L.E. Kopp

13. P. hexanthera L.E. Kopp

14. P. jenmanii $\mathrm{Mez}$

15. P. lemensis H. Ferrer \& Sanoja

AM, AR, BA, BO, CO, DC, FA, GU,
LA, ME, MI, MO, SU, TA, YA, ZU
AM
ME
AR, BA, CA, DC, FA, LA, ME, MI,
MO, NE, PO, TA, TR, ZU
AM
AM

TR

$\mathrm{AM}, \mathrm{BO}$

AM, BO

AM

AM

AR

LA, TA, TR

AM

AM, BO

AR, FA

AM, BO

$\mathrm{BO}$
Rango altitudinal registrado (msnm)

100-1.900

700

2.100-2.200

$350-2.200$

1.770-1.850

No reportado

1.300-1.650

800-2.400

800-1.800

1.800-2.000

1.750-1.850

1.200-2.200

2.100-3.300

80-140

1.100-1.400

500-1.400

1.000-1.500

430-1.350 
Tabla 1 (continuación)

\begin{tabular}{lll}
\hline Taxones & Distribución por Estados & $\begin{array}{l}\text { Rango altitudinal } \\
\text { registrado (msnm) }\end{array}$ \\
\hline 16. P. maguirei L.E. Kopp & AM & 1.400 \\
17. P. meridensis L.E. Kopp & ME, PO, TR & $1.300-2.150$ \\
18. P. mutisii Kunth & AN, AP, ME, MO, SU, TA, TR & $1500-3.300$ \\
19. P. perseiphylla (C.K. Allen) van der Werff & AM & $650-1.700$ \\
20. P. povedae W.C. Burger & AR, ME & $600-1.500$ \\
21. P. pseudofasciculata L.E. Kopp & AM & $140-1.100$ \\
22. P. rigens C.K. Allen var. oblaticarpa & AN, LA, MO, PO, SU, TR & $1.000-2.300$ \\
H. Ferrer & ME & $2.450-2.650$ \\
23. P. ruizii J.F. Macbr. & AN, TA, TR & $1.800-2.500$ \\
24. P. subcordata (Ruiz \& Pav.) Nees &
\end{tabular}

1. Persea americana Mill., Gard. Dict. ed. 8; $1768 \equiv$ Laurus persea L. Tipo: "Habitat in America calida". Sloane, Voy. Jamaica 2: 132, t. 222, f. 21725 (Lectótipo designado por van der Werff 2002, BM, no visto).

Figuras 1I, 3B, 8A.

Árbol, $15 \mathrm{~m}$ alt.; ramas con sección transversal terete o angular, glabras o con tricomas lisos, amarillentos, lisos a ondulados, erectos o ascendentes con cobertura muy laxa a medianamente densa; yemas apicales cortas, con indumento igual que las ramas o glabras. Hojas distribuidas a lo largo de las ramas, raras veces agrupadas en las puntas; pecíolos 3,0-3,8 × 0,12-0,24 cm, acanalados, glabros o con tricomas amarillentos, lisos a ondulados, erectos o ascendentes con cobertura muy laxa a medianamente densa; láminas foliares elípticas, 7,5-23,7 × 3,9-10,0 cm, glabras o pubescentes como los pecíolos, ápice agudo, raras veces obtuso, acuminado, base obtusa, margen entero, con el nervio medio ligeramente más ancho en la mitad basal, hundido en la haz, glabro; venación eucamptódroma, 7-8 pares de venas secundarias, divergentes en ángulo agudo hasta obtuso, rectas, ramificadas antes de alcanzar el margen, anastomosadas, cerrándose por arcos secundarios formados por venas de $3^{\circ} \mathrm{y} 4^{\circ}$ orden, con patrón reticulado ortogonal; venación marginal formando lazos cerrados, areolas perfectamente desarrolladas, de forma angular, con venillas simples o ramificadas dentro de la areola. Inflorescencias en panículas subterminales y axilares, hasta $22,0 \mathrm{~cm}$ long., alcanzando desde $1 / 2$ hasta la longitud de las hojas adyacentes. Flores 5,5-7,5 mm long., pedicelos
2,5-4,7 mm long. Tépalos iguales a subiguales entre sí, patentes, con tricomas ondulados a lisos, ascendentes o erectos, en ambas caras. Estambres fértiles 9; anteras de V1 y V2 ovadas, 4 lóculos, con dehiscencia introrsa, glabras, filamentos hasta tres veces la longitud de las anteras, pubescentes; anteras del V3 ovadas a oblongas, con dehiscencia extrorsa, glabras, filamentos hasta tres veces la longitud de las anteras, pubescentes, acompañados de un par de glándulas ovadas, estipitadas, adnadas en la parte basal del filamento; estaminodios 3, sagitados, hasta $1,0 \mathrm{~mm}$ long., glabros o pubescentes; ovario esférico a elipsoidal, cubierto por tricomas lisos, amarillentos, ascendentes con cobertura muy laxa a medianamente densa, estilo ligeramente más largo que el ovario. Fruto piriforme, obovado o esférico, 5,0-25,0 ×3,0-15,0 cm.

Persea americana se distribuye naturalmente por toda Centroamérica y se considera introducida y naturalizada en América del Sur. Esta es la única especie colectada en todos los estados del país, al norte y sur del Orinoco, lo cual está claramente influido por su utilidad agronómica. Se considera que fue introducida desde Centroamérica o Perú por diversas etnias indígenas y luego se naturalizó, llegando a encontrar especímenes silvestres en áreas protegidas como el Parque Nacional Henri Pittier. En virtud de esta información, se considera que esta especie está representada por la variedad de P. americana var. americana, mejor conocida como la raza antillana. Persea americana pertenece al subgénero Persea y se distingue por presentar frutos con más de $5,0 \mathrm{~cm}$ de longitud y tépalos iguales a subiguales, caducos individualmente durante la fructificación. 


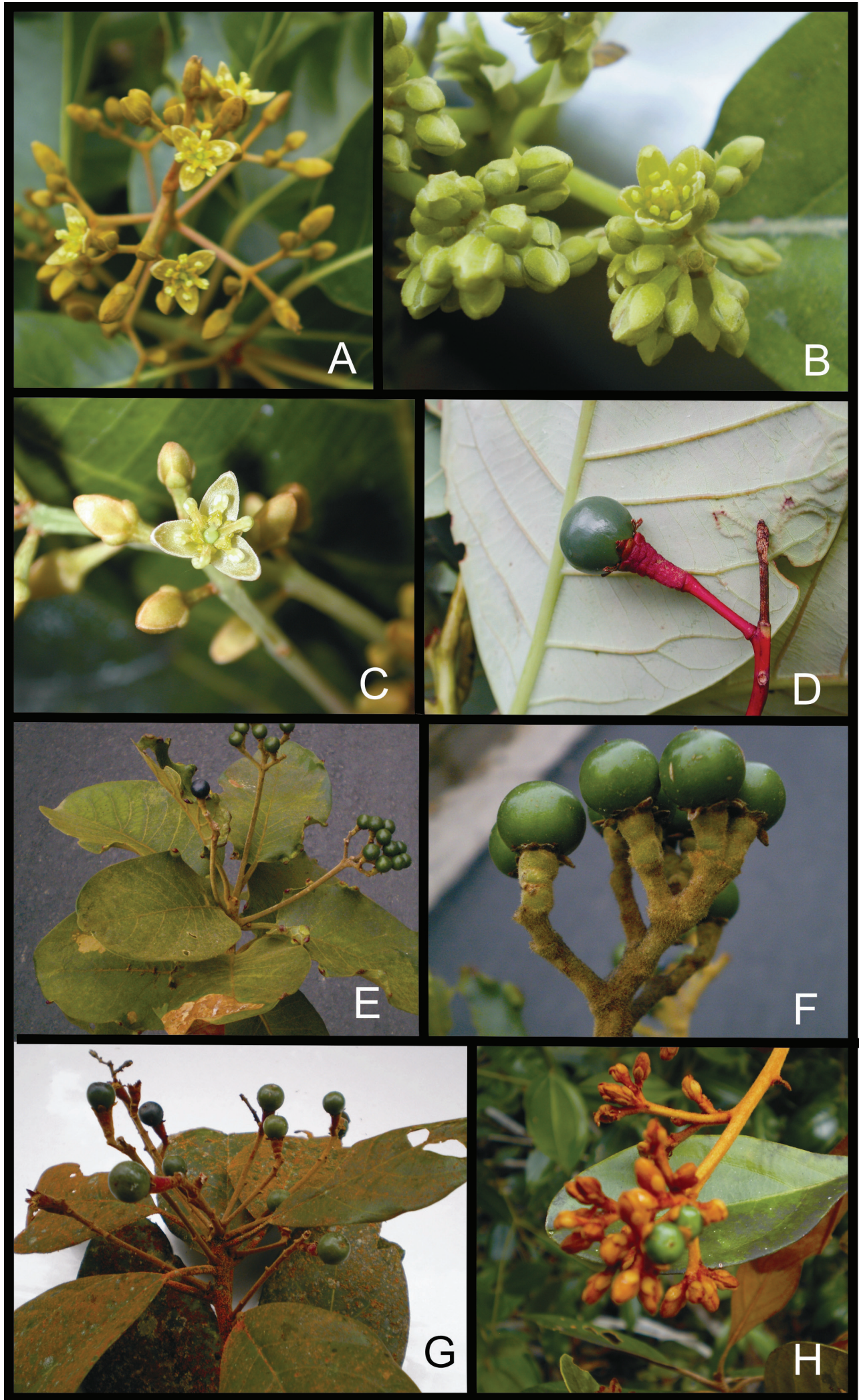

Figura 3. Imágenes de ejemplares colectados en campo. A. P. caerulea. B. P. americana. C, D. P. lemensis. E, F. P. subcordata. G. P. meridensis. H. P. jenmani. (Imágenes C y D fueron tomadas por el Dr. Elio Sanoja).

Figure 3. Images of fresh samples. A. P. caerulea. B. P. americana. C, D. P. lemensis. E, F. P. subcordata. G. P. meridensis. H. P. jenmani. (Images $\mathrm{C}$ and D were taken by Dr. Elio Sanoja). 
En ocasiones, los ejemplares de esta especie pueden tener hojas de hasta $30 \mathrm{~cm}$ y frutos de diferentes formas, texturas y colores. Posiblemente esta variación fue derivada del efecto antrópico de la domesticación a la cual ha sido sometida desde hace 10.000 años en Centroamérica por culturas precolombinas. No obstante, es necesario analizar los materiales nativos y extranjeros a través nuevas herramientas para obtener evidencias que soporten la circunscripción taxonómica de la especie, sus variedades botánicas y cultivadas, así como los híbridos concebidos por mejoramiento genético o cruzamiento aleatorio.

Materiales examinados: VENEZUELA. AmAzonAs: Middle reaches of right bank tributary of upper Cuao river, 12-VI-1985, S. Zent 685-07 (VEN). Aragua: $5 \mathrm{~km}$ from Portachuelo, along road from maracay to Ocumare de la Costa, fallen tree along roadside, 25-X-1974, P.J.M. Maas \& V. Badillo 2173 (VEN, K). BARINAS: Barrancas, Municipio Cruz Paredes, Distrito Obispos, 27-II-1979, G. Aymard \& P. Salcedo 34 (MER). Bolívar: San Félix, 24-VIII-1991, E.G. A.Z. - C.G. 6 (GUYN). CoJedEs: Distrito San Carlos, Municipio Angel Bravo, Las Tucuraguas, 22-IX-1986, F. Delascio \& R. López 12843 (VEN). Distrito CAPITAL: La Pastora, around Caracas, 28-II-1913, H. Pittier 5913 (F, US). Falcón: San Luis, Sierra de San Luis, camino desde el Hotel Parador hacia Paraguariba, 24-II-1980, R. Wingfield 7514 (CORO). GuÁrICo: San Juan de los Morros, 30-I-1922, H. Pittier 10160 (VEN, HUH). Lara: Distrito Palavecino, Buria, Finca La Lucenera, 24-III-1989, F. Delascio \& L. M. de Delascio 13899 (VEN). MéridA: Municipio Tabay, La Mucuy, 1 km O, 15 km E de Mérida, 18-VII-1953, E. Little Jr. 15338 (VEN, MER). MiRANDA: orilla de la carretera, entre Agua Blanca y Santa Crucita, Parque Nacional Guatopo, Municipio Acevedo, 15-V-2001, H. Rodríguez 3668 (MY). Monagas: sector El Mirador de Caripe, 8-XI-1999, A. Lárez et al. 7281 (UOJ). Sucre: Sabilar, carretera Cumaná-San José de Macarapana, 23-V-1970, L.J. Cumana 94 (IRBR). TÁCHIRA: Embalse del Uribante, Distrito Uribante, 9-X-1983, M. T. Belandria 67 (MER). YARAcUY: Distrito San Felipe, al NO de Nirgua, Montaña El Zapatero, parte SO, Fila Jaiguao, caserío Mundo Nuevo: vertiente norte, 10-IV-1999, W. Meier \& O. Kunert 4762 (VEN). Zulia: Distrito Bolívar: vía entre El Pensado y Las Tres Marías, trayecto de 8 km, 7-II-1980, G.S. Bunting \& F. Arboleda 8731 (VEN).
2. Persea areolatocostae (C.K. Allen) van der Werff, Ann. Missouri Bot. Gard. 76(2): 471. $1989 \equiv$ Phoebe areolatocostae C.K. Allen, Mem. New York Bot. Gard. 10(5): 75. 1964. Tipo: VENEZUELA. Amazonas: Cerro La Neblina, Rio Yatua, justnorth of Camp 3, 650-700 msnm, 17-XI-1957, B. Maguire et al. 42085 (Holótipo NY!, Isótipo VEN!). Figura $8 \mathrm{~B}$.

Árbol, 4-15 m alt.; ramas con sección transversal terete, con tricomas blanquecinos, amarillentos o parduzcos, lisos, adpresos con cobertura laxa a medianamente densa; yemas apicales cortas, con indumento igual que las ramas. Hojas distribuidas a lo largo de las ramas; pecíolos 1,6-2,2 $\times 0,15 \mathrm{~cm}$, acanalados, pubescentes; láminas foliares elípticas, $13,0-15,5 \times 4,8-6,6 \mathrm{~cm}$, con largo:ancho igual a $2: 1$ a $3: 1$, con tricomas blanquecinos, amarillentos o parduzcos, lisos, adpresos con cobertura laxa en la cara abaxial, ápice agudo, acuminado, base aguda, decurrente o cuneada, margen entero o ligeramente revoluto en la base de la lámina; nervio medio glabro o con tricomas; venación broquidódroma a eucamptódroma, 7 pares de venas secundarias, divergentes en ángulo obtuso, curvas, ramificadas antes de alcanzar el margen, anastomosadas, cerrándose por arcos secundarios formados por venas de $3^{\circ}$ y $4^{\circ}$ orden, con patrón reticulado ortogonal; venación marginal formando lazos cerrados, areolas perfectamente desarrolladas, de forma angular o redondeada, con venillas ramificadas dentro de la areola. Inflorescencias en panículas subterminales o axilares, hasta $7,5 \mathrm{~cm}$ long., alcanzando $1 / 2$ a $1 / 3$ de la longitud de las hojas adyacentes. Flores $6,0 \mathrm{~mm}$ long.; pedicelos 2,0 $\mathrm{mm}$ long., engrosados hacia el receptáculo. Tépalos iguales a subiguales entre sí, erectos, con tricomas blanquecinos, amarillentos o parduzcos, lisos, adpresos con cobertura laxa en ambas caras. Estambres fértiles 9; anteras de V1 y V2 ovadas, $0,6 \times 0,5 \mathrm{~mm}, 4$ lóculos, con dehiscencia introrsa, glabras, filamentos hasta $0,5 \mathrm{~mm}$ long., pubescentes; anteras del V3 triangulares, $0,6 \times 0,4 \mathrm{~mm}, 4$ lóculos, con dehiscencia extrorsa, glabras, filamentos hasta $0,6 \mathrm{~mm}$ long., de igual longitud que las anteras, pubescentes, acompañados de un par de glándulas redondeadas, sésiles, adnadas en la parte basal del filamento; estaminodios 3 , sagitados, hasta $0,7 \mathrm{~mm}$ long., pubescentes; ovario esférico, 1,0 × 1,0 mm, glabro, estilo igual longitud que el ovario. Fruto no visto.

Persea areolatocostae ha sido reportada en Brasil, Bolivia, Colombia, Ecuador, Perú y Venezuela 
(W3TROPICOS 2011). En Venezuela, sólo se ha colectado en el Estado Amazonas entre $100 \mathrm{y}$ $700 \mathrm{msnm}$.

Se distingue por las areolas conspícuas en la cara adaxial de las hojas, cerca del nervio medio, así como por las venas ascendentes y arcuadas que suelen llegar cerca del margen y luego confluyen con la vena inmediata superior. La especie más similar es $P$. fendleri de la cual se diferencia por el tamaño de las flores, la distribución del indumento y las glándulas sésiles subbasales en el tercer verticilo estaminal. Otras diferencias se discuten bajo las anotaciones del taxón antes mencionado.

Se consideraba que esta especie era endémica de Venezuela; sin embargo, las fotografías de las colecciones extranjeras muestran caracteres que sobresalen de la descripción original por lo que podría tratarse de dos especies distintas o con una gran plasticidad que deberá ser estudiada con mayor detalle. El ejemplar Maguire 29342 (NY) fue descrito bajo $P$. steyermarkii por Kopp, pero en este trabajo queda transferido a $P$. areolatocostae.

Materiales examinados: VENEZUELA. AmAZonAs: Cerro de la Neblina, Río Yatua, in slope forest just north of Camp 3, 1-I-1958, B. Maguire et al. 42572
(F); common at edge of small laja, Río Temi 1 hour below Yavita, medium-sized riverine tree with pale, cream-colored, fragant flowers, B. Maguire 29342 (NY).

3. Persea bernardii L.E. Kopp, Mem. New York Bot. Gard. 14(1): 100. 1966. Tipo: VENEZUELA. MÉrIDA: Pueblos del Sur, El Japón, cercanías aldea La Providencia, 2.100-2.200 msnm, 31-III-1957, A.L. Bernardi 6450 (Holótipo NY, Isótipo MER).

Figuras 1E, 8C.

Árbol, ramas con sección transversal angular, cubiertas por tricomas amarillentos, ondulados, generalmente ascendentes y con cobertura densa; yemas apicales cortas, con indumento igual que las ramas. Hojas agrupadas en las puntas de las ramas; pecíolos acanalados, pubescentes; láminas foliares elípticas, $10,0-12,0 \times 5,0-7,0 \mathrm{~cm}$, con tricomas amarillentos, ondulados, generalmente ascendentes y con cobertura densa en la cara abaxial, ápice obtuso, base aguda, margen ligeramente revoluto, en la base de la lámina, con el nervio medio hundido en la haz, pubescente; 7 pares de venas secundarias, divergentes en ángulo obtuso, curvas. Inflorescencias en panículas axilares, hasta $15,0 \mathrm{~cm}$ long., tan largas como las

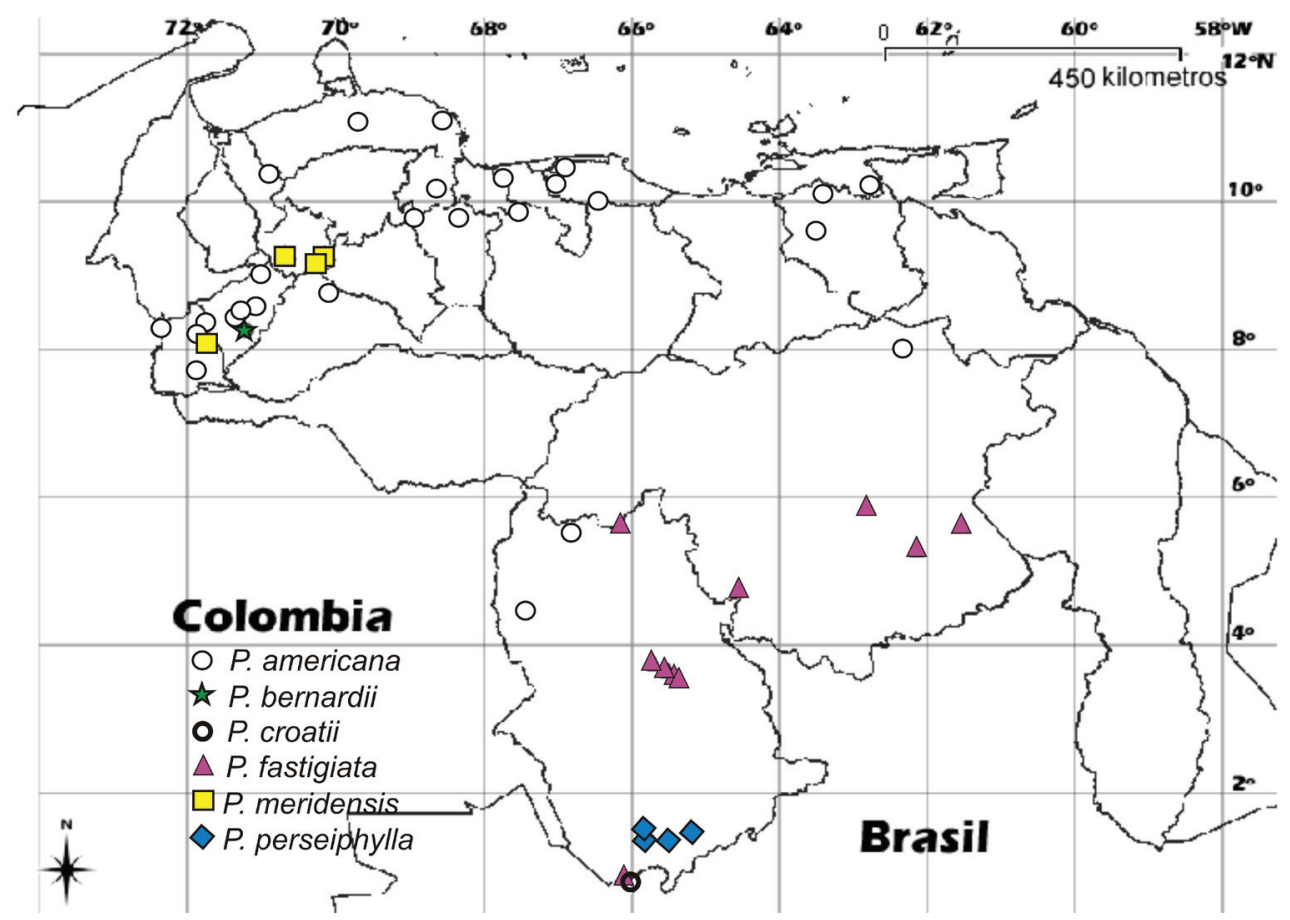

Figura 4. Distribución de $P$. americana, $P$. bernardii, $P$. croatii, $P$. fastigiata, $P$. meridensis y $P$. perseiphylla en Venezuela, según datos de herbario.

Figure 4. Distribution map for P. americana, P. bernardii, P. croatii, P. fastigiata, P. meridensis, and P. perseiphylla in Venezuela, based on herbaria data. 
hojas adyacentes. Tépalos iguales a subiguales entre sí, patentes, tanto los externos como los internos, cubiertos por tricomas amarillentos, fuertemente ondulados, erectos y con cobertura medianamente densa en ambas caras. Estambres fértiles 9; anteras del V1 y V2 trapezoidales, $1,2 \times 0,75 \mathrm{~mm}, 4$ lóculos, con dehiscencia introrsa, glabras, filamentos hasta $1,0 \mathrm{~mm}$ long., de igual longitud que las anteras, pubescentes; anteras del V3 rectangulares, 1,5 × 0,4 mm, 4 lóculos, con dehiscencia extrorsa-latrorsa, glabras, filamentos hasta 1,5 mm long., de igual longitud que las anteras, pubescentes, acompañados de un par de glándulas redondeadas, sésiles, adnadas a $1 / 4$ de la longitud del filamento; estaminodios 3, sagitados, hasta 1,3 mm long., pubescentes; ovario ovado, $1,2 \times 0,9 \mathrm{~mm}$, glabro, estilo 2,0 $\mathrm{mm}$ long., más largo que el ovario. Tépalos y estambres pubescentes y persistentes en la fructificación. Fruto desconocido.

Persea bernardii es endémica de Venezuela, sólo se conoce de la colección tipo colectada en Pueblos del Sur, Mérida.

Esta especie se reconoce por el denso indumento de tricomas ondulados que cubre las hojas, ramas y flores. van der Werff (2002) señaló que esta especie pertenece a un grupo de características anómalas que no puede ser circunscrito dentro de la clasificación subgénerica propuesta por Kopp (1966), pero en vista del escaso número de colecciones no se han llevado estudios más intensivos. La especie más afín es $P$. subcordata, con la cual comparte el rango de distribución horizontal y vertical, y se diferencian por los tépalos subiguales y los caracteres del indumento.

4. Persea caerulea (Ruiz \& Pav.) Mez, Jahrb. Königl. Bot. Gart. Berlin 5: 171. 1889 =Laurus caerulea Ruiz \& Pavón, Fl. Peruv. 4: t.350. 1802. Tipo: PERÚ. Ruiz \& Pavon s.n. (MA, no visto).

$=$ Persea lignitepala Lasser, Bol. Soc. Venez. Ci. Nat. 9: 177. 1944.

Figuras 1H, 2B, 3A.

Árbol hasta $25 \mathrm{~m}$ alt., 5-40 cm. DAP; ramas con sección transversal angular, con tricomas amarillentos a blanquecinos, lisos, adpresos a ascendentes, con cobertura laxa a medianamente densa; yemas apicales cortas, con indumento igual que las ramas. Hojas distribuidas a lo largo de las ramas; pecíolos 2,1-4,0 × 0,14-0,18 cm, acanalados, glabros o con tricomas amarillentos a blanquecinos, lisos, adpresos a ascendentes, con cobertura laxa a medianamente densa; láminas foliares ovadas a elípticas, 7,2-22,3 × 4,2-9,7 cm, con largo:ancho igual a 2:1, a menudo cubiertas por tricomas amarillentos a blanquecinos, lisos, adpresos a ascendentes, con cobertura laxa a medianamente densa, ápice agudo, acuminado, base obtusa, cuneada, ligeramente cordada o desigual, margen entero; nervio medio glabro, rara vez pubescente; venación broquidódroma a eucamptódroma, 9-12 pares de venas secundarias, divergentes en ángulo agudo o recto, rectas o curvas, ramificadas antes de alcanzar el margen, a menudo anastomosadas, cerrándose por arcos secundarios formados por venas de $3^{\circ}$ y $4^{\circ}$ orden o uniéndose en ángulo agudo o recto a la vena secundaria supradyacente, con patrón reticulado ortogonal; venación marginal formando lazos cerrados, areolas perfectamente desarrolladas, de forma angular, con venillas rectilíneas o sin ellas dentro de la areola. Inflorescencias en panículas subterminales o axilares, hasta $20,0 \mathrm{~cm}$ long., alcanzando $1 / 2$ a $3 / 4$ de la longitud de las hojas adyacentes. Flores 5,0-6,0 × 8,0 mm diám., pedicelos 2,0-5,0 mm long., teretes. Tépalos conspicuamente desiguales entre sí, los tres externos tan largos como un cuarto o menos que los internos, patentes, los externos pubescentes sólo en la cara abaxial, mientras que los internos presentan tricomas amarillentos a blanquecinos, lisos, adpresos, con cobertura medianamente densa en ambas caras. Estambres fértiles 9; anteras de V1 y V2 ovadas, $0,8-1,0 \times 0,6-0,8 \mathrm{~mm}, 4$ lóculos, con dehiscencia introrsa, glabras, filamentos hasta $2,0 \mathrm{~mm}$ long., ligeramente más largos o hasta dos veces la longitud de las anteras, pubescentes; anteras del V 3 triangulares, 0,6-1,2 × 0,4-0,5 mm, 4 lóculos, con dehiscencia extrorsa-latrorsa, cubiertas pubescentes, filamentos hasta 2,0-2,7 mm long., dos o tres veces más largos que las anteras, pubescentes, acompañados de un par de glándulas cordadas, sésiles, adnadas a $1 / 3$ de la longitud del filamento; estaminodios 3, sagitados, hasta 2,0 mm long., pubescentes; ovario esférico o elipsoidal, $0,8-1,2 \times 0,4-1,2 \mathrm{~mm}$, glabro, estilo 1,8-2,8 mm long., más largo que el ovario. Frutos globosos o deprimido-globosos, 7,7-12,0 mm diám., pedúnculos 5,0-8,0 $\mathrm{mm}$ long., alargados, de textura lisa; tépalos parcialmente caducos, pubescentes; estambres persistentes en el fruto.

Persea caerulea ha sido reportada desde Honduras hasta Bolivia, exceptuando Brasil. Es la especie más colectada en Venezuela y la más común en estado silvestre al norte del Orinoco. Se considera como una especie pionera en los estratos arbóreos 
de la vegetación secundaria y puede encontrarse dentro de los bosques nublados y a lo largo de áreas intervenidas como carreteras y potreros. Los frutos son comúnmente utilizados en farmacognosia para la extracción de sedantes potentes que pueden ser utilizados como veneno para perros y ratas.

Se reconoce en campo y en pliegos de herbario por la longitud de los tépalos, siendo los externos hasta cuatro veces más cortos que los internos. Durante la fructificación, los pedúnculos no se engrosan y los extremos de los tépalos internos son persistentes y a medida que el fruto madura, se fracturan y caen, quedando de longitud similar a los externos.

Materiales examinados: VENEZUELA. Aragua: Colectada detrás de la Estación Biológica, Parque Nacional Henri Pittier, 24-V-2001, A. Cardozo et al. 2838 (VEN, MER). BARINAs: Distrito Bolívar, El Celoso a orillas de la carretera Mérida-Barinas, poco antes del caserío La Soledad, 12-X-1961, L. Ruiz-Terán 731 (HERZU, MER). CARABobo: alrededores del bosque de galería en camino que conduce hacia La Toma, Hacienda Guataparo, Valencia, 19-III-1996, E. Jimenez et al. 217 (MY). Distrito Capital: middle Cotiza near Caracas, IV-1917, H. Pittier 7106
(US). FALCón: Sierra de San Luis, arriba de Uria, 8-IV-1979, R. Wingfield 5775 (VEN, CORO). LARA: Municipio Palavecino, Parque Nacional Terepaima, después del Ficus a orilla de la carretera, 30-VI-00, H. Alvarado \& E. Giménez 321 (UCOB). MéridA: "El Chorro". Cerro de las Quebraditas, camino a La Azulita, 10-V-1952, F. Pannier 216 (VEN, MER). Miranda: quebradas afluentes al Río Guarita, al sur del Cementerio Monumental del Este, 17-VIII-1975, J. Steyermark \& P. Berry 112064 (VEN). Monagas: rocky open slopes between Caripe and San Agustín, 5-IV-1945, J.A. Steyermark 61786 (VEN, F). NuEVA Esparta: cloud forest edge, 7-IV-1983, A. Sugden 1138 (VEN, K). Portuguesa: vía La Estación hacia La Lucía, 30-VI-1977, R.F. Smith V8574 (VEN). TÁCHIRA: ramal entre Pregonero y Guaraque, entre el Centro de Salud y la quebrada La Playa, 24-VI-1978, L. Ruiz-Terán et al. 15447 (MERF). TRUJILlo: new road from Timotes to Valera, between Timotes and La Puerta, 20-III-1969, B. \& F. Oberwinkler 15140 (MER). ZuLIA: Loma boscosa a lo largo de la quebrada del Río Omira-kuná (Tumuriasa), cerca de la frontera Colombo-Venezolana suroeste de Pishikao e Iría, 25-III-1972, J. Steyermark et al. 105659 (VEN).

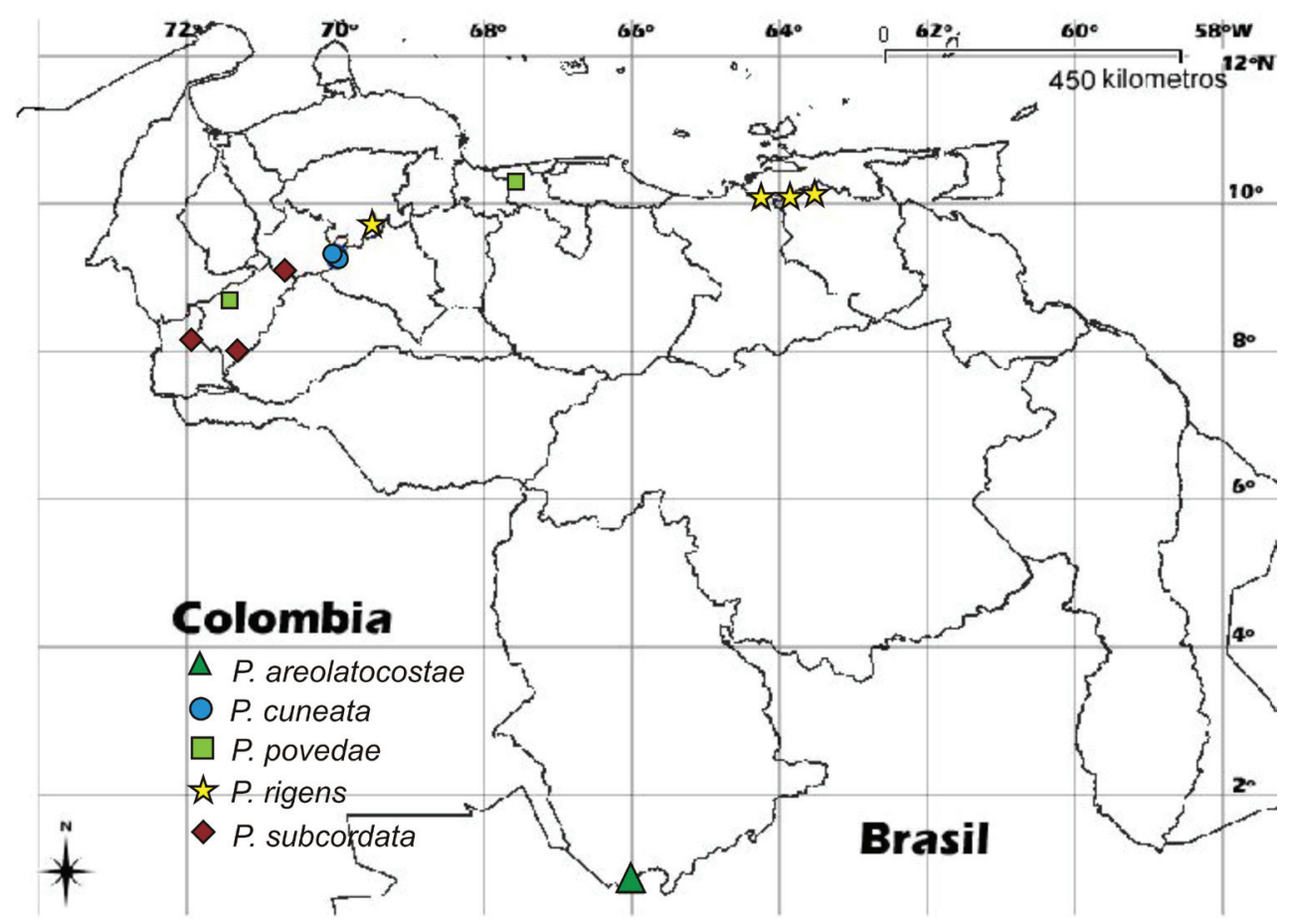

Figura 5. Distribución de P. areolatocostae, P. cuneata, P. povedae, P. rigens var. oblaticarpa y P. subcordata en Venezuela, según datos de herbario.

Figure 5. Distribution map for P. areolatocostae, P. cuneata, P. povedae, P. rigens var. oblaticarpa, and P. subcordata in Venezuela, based on herbaria data. 


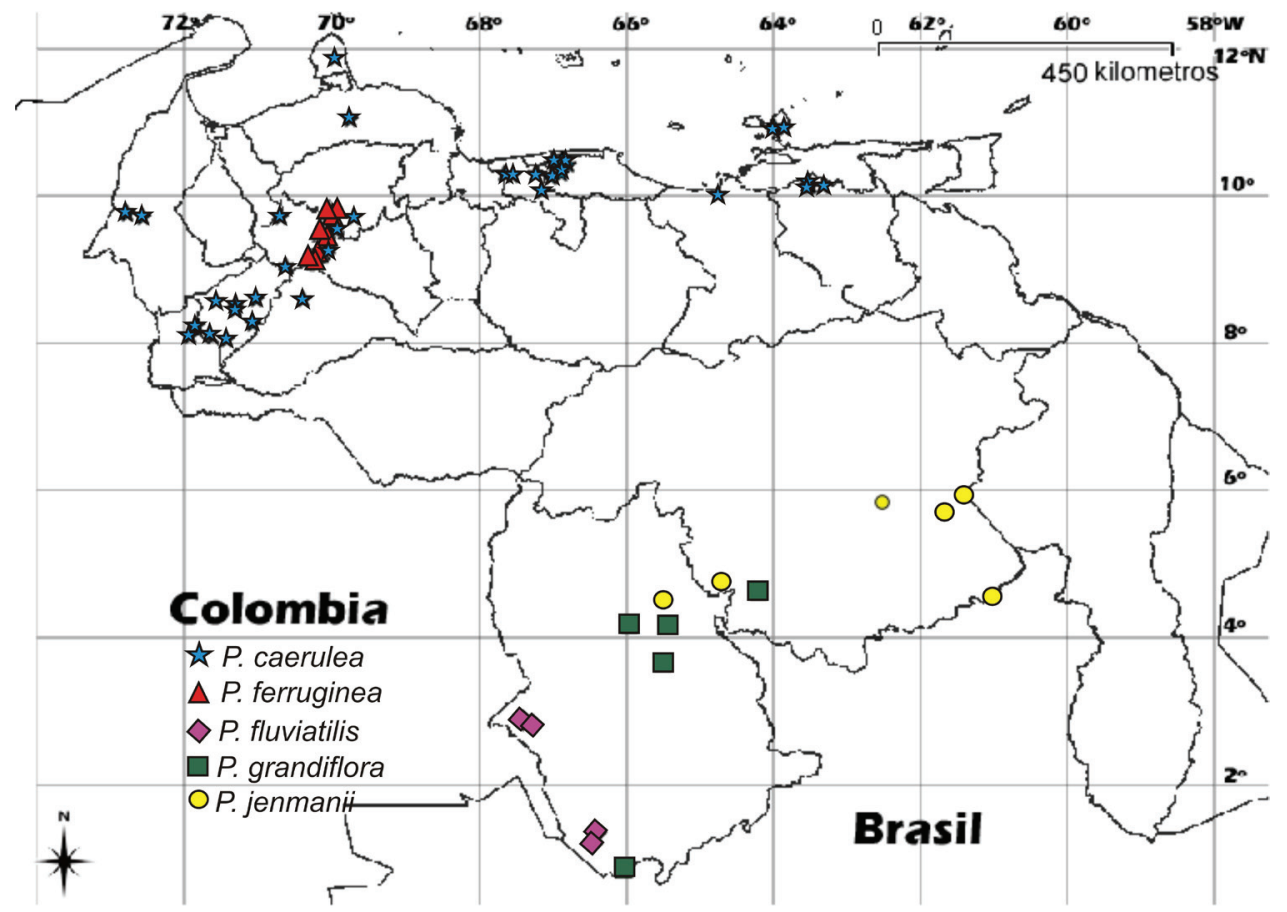

Figura 6. Distribución de P. caerulea, P. ferruginea, P. fluviatilis, P. grandiflora y $P$. jenmanii en Venezuela, según datos de herbario. Figure 6. Distribution map for P. caerulea, P. ferruginea, P. fluviatilis, P. grandiflora, and P. jenmanii in Venezuela, based on herbaria data.

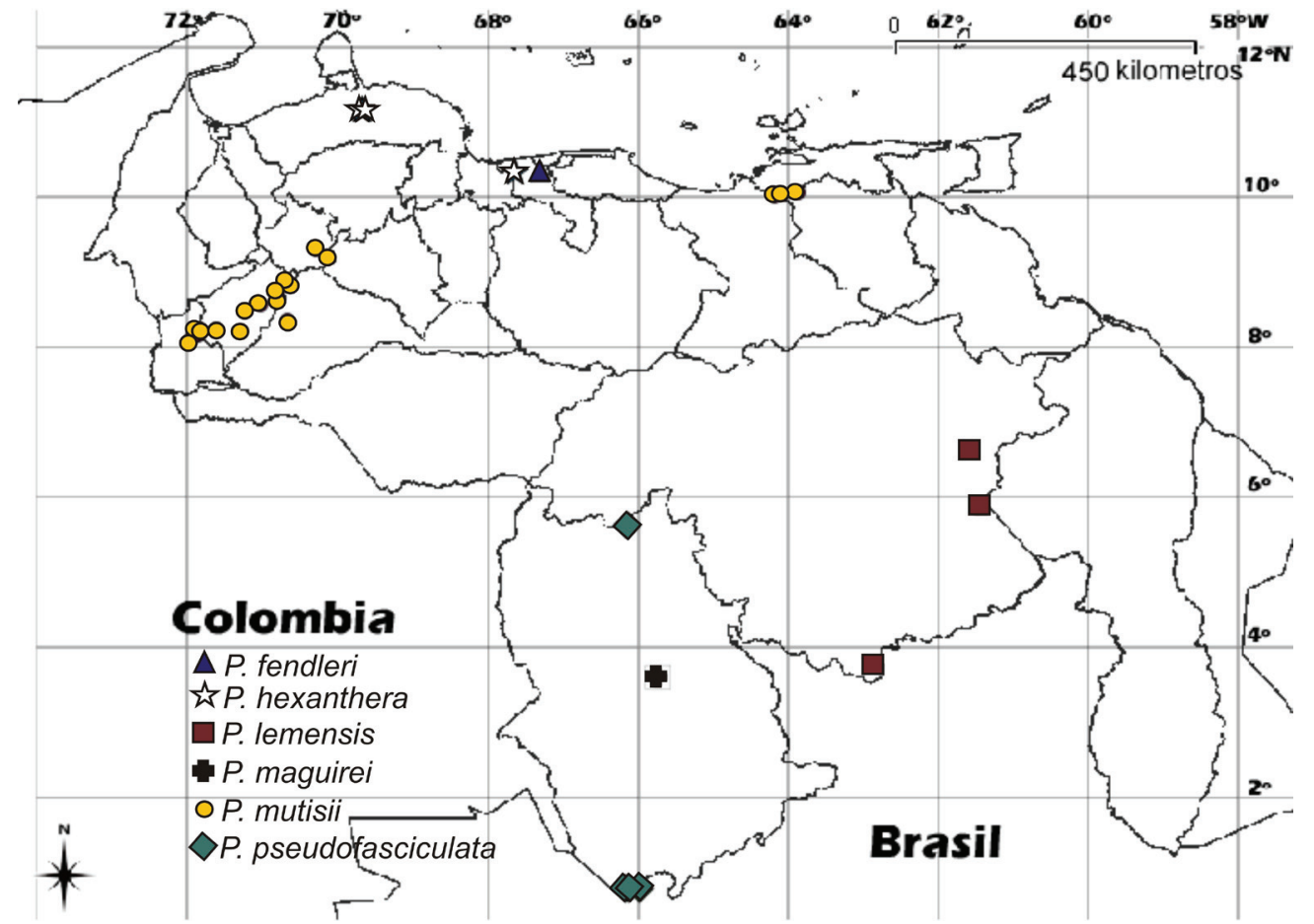

Figura 7. Distribución de P. fendleri, P. hexanthera, P. lemensis, P. maguirei, P. mutisii y P. pseudofasciculata en Venezuela, según datos de herbario.

Figure 7. Distribution map for P. fendleri, P. hexanthera, P. lemensis, P. maguirei, P. mutisii, and P. pseudofasciculata in Venezuela, based on herbaria data. 
5. Persea croatii van der Werff, Ann. Missouri Bot. Gard. 76(2): 471. 1989. Tipo: VENEZUELA. Amazonas: Cerro Neblina, camp\#7, south slopes of Cañon Grande, along new path to river and along river, 1.770-1.850 msnm, 30-XI-1984, T.B. Croat 59519 (Isótipo VEN!).

Figura 8D.

Árbol; ramas con sección transversal angular, con tricomas parduzcos, lisos, adpresos, con cobertura medianamente densa; yemas apicales cortas, con indumento igual que las ramas. Hojas distribuidas a lo largo de las ramas; pecíolos $1,20 \times 0,12 \mathrm{~cm}$, acanalados, pubescentes; láminas foliares elípticas, 10,3-12,0 × 3,3-5,0 cm, con largo:ancho igual a $2: 1$ a $3: 1$, cubiertas por tricomas parduzcos, lisos, adpresos, con cobertura medianamente densa, ápice agudo, redondeado, base aguda, decurrente, margen ligeramente revoluto, en toda la longitud de la lámina; nervio medio cóncavo en la haz, densamente pubescente; venación broquidódroma, 8 pares de venas secundarias, divergentes en ángulo recto, curvas, anastomosadas, uniéndose en ángulo obtuso a la vena secundaria supradyacente. Inflorescencias en panículas axilares, hasta $12,0 \mathrm{~cm}$ long., alcanzando $1 / 4$ o menos de la longitud de las hojas adyacentes. Flores $8,0 \mathrm{~mm}$ long.; pedicelos 9,5 mm long., engrosados hacia el receptáculo. Tépalos conspicuamente desiguales entre sí, los tres externos tan largos como la mitad de los internos, erectos, con tricomas parduzcos, lisos, adpresos, con cobertura medianamente densa en la cara abaxial, mientras que los internos presentan tricomas que cubren ambas caras. Estambres fértiles 9; anteras de V1 y V2 ovadas, 1,6 mm long., 4 lóculos, con dehiscencia introrsa, glabras, filamentos hasta $3,1 \mathrm{~mm}$ long., dos veces la longitud de las anteras, pubescentes; anteras del V3 rectangulares, 1,5 $\mathrm{mm}$ long., 4 lóculos, con dehiscencia extrorsa-latrorsa, glabras, filamentos hasta 3,0 mm long., dos veces más largos que las anteras, pubescentes, acompañados de un par de glándulas redondeadas, sésiles, adnadas a 1/4 de la longitud del filamento; estaminodios 3, sagitados, con tricomas adpresos; ovario esférico, con tricomas en el ápice del ovario y base del estilo, estilo 3,0 mm long., más largo que el ovario. Fruto desconocido.

Persea croatii es endémica de Venezuela y sólo se conoce del tipo, colectado en el Cerro de la Neblina (Estado Amazonas). Tiene hojas elípticas, subcoriáceas, distribuidas regularmente a lo largo de las ramas, con tricomas adpresos en el envés.
Las inflorescencias son subterminales y/o axilares, paniculadas, casi tan largas como las hojas. Los caracteres más destacados son el tamaño de la flores (6-7 $\mathrm{mm}$ de largo) y el ovario pubescente, lo cual sitúa a $P$. croatii en la sección Aurataea junto con $P$. grandiflora y $P$. maguirei. Puede diferenciarse de $P$. maguirei ya que tiene hojas más largas, con ápice agudo, y por la escasa cobertura de los tricomas en el envés. También se distingue de $P$. grandiflora por la corta longitud de sus inflorescencias (alcanzan menos de $1 / 4$ de la longitud de las hojas) y el contorno elíptico de las hojas, de apariencia lanceolada, nunca anchamente ovadas.

6. Persea croizatii van der Werff, Ann. Missouri Bot. Gard. 76(2): 472. 1989. Tipo: VENEZUELA. Amazonas: upper Rio Orinoco, 1951, Croizat 918 (Holótipo F, Isótipo US, fototipos!).

Figura 9A.

Basado en la descripción original (van der Werff 1989a), P. croizatii se distingue por las siguientes características: "Árbol de tamaño desconocido. Ramas teretes, pubescentes cuando jóvenes, siendo caducos en la adultez. Hojas elípticas, 9-14 × 4-6 cm, cartáceas, ápice y base agudos, margen ligeramente revoluto, con poca pubescencia en la cara abaxial, 5-6 pares de venas secundarias, nervios terciarios y cuaternarios visibles. Pecíolos glabros o ligeramente pubescentes en la base, 2-3 cm long. Inflorescencias tan largas como las hojas que las subtienden, pubescentes. Tépalos desiguales, los externos con tricomas en la cara adaxial y los internos pubescentes en ambas caras. Estambres fértiles 9; anteras de V1 y V2 glabras, introrsas, 4 lóculos, filamentos pubescentes, tan largos como las anteras; anteras de V3 glabras, rectangulares, extrorsas-latrorsas, 4 lóculos, filamentos pubescentes, ligeramente más largos que las anteras, con un par de glándulas redondeadas, sésiles, adnadas ligeramente por encima del filamento; estaminodios 3, sagitados; ovario glabro. Fruto globoso, ca. $8 \mathrm{~mm}$ diám., glaucos; con tépalos y estambres persistentes, pubescentes".

Al igual que el taxón anterior, sólo se conoce del tipo y no se tienen datos sobre ecología ni ubicación precisa. Holst \& Todzia (1990) señalan que pudo haber sido colectada en Ugueto (Estado Amazonas), el punto más lejano al que llegó Croizat durante la exploración a las cabeceras del Río Orinoco, acompañado de Pablo Anduze y Luis Carbonell.

En esta especie, las hojas tienen apariencia glauca, las inflorescencias son tanto o ligeramente más largas 


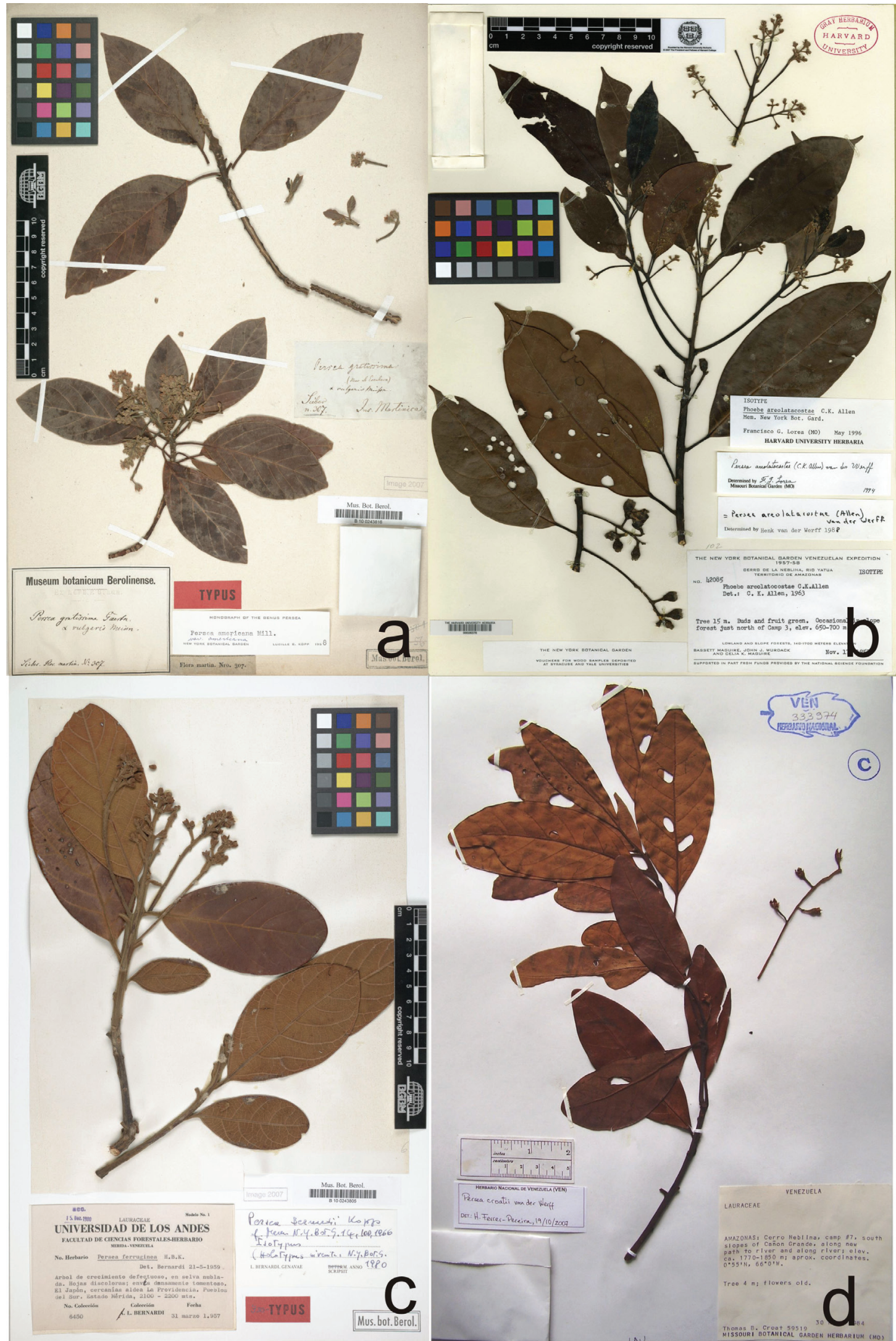

Figura 8. Imágenes de las colecciones examinadas. A. Persea americana. B. P. areolatocostae. C. P. bernardii. D. P. croatii. Figure 8. Images of examined vouchers. A. Persea americana. B. P. areolatocostae. C. P. bernardii. D. P. croatii. 
que las hojas y los estambres del tercer verticilo son más largos que los de los verticilos externos, lo cual destaca como el carácter más resaltante mencionado en la descripción. Por tales características y su distribución, se distingue de $P$. lemensis, especie afín con la cual comparte ubicación en la sección Eriodaphne del subgénero Eriodaphne.

7. Persea cuneata Meisn. in A.DC. Prodr. 15(1): 46. 1864. Tipo: COLOMBIA. Jervise s.n. (Holótipo K!).

Figuras $2 \mathrm{G}, 9 \mathrm{C}$.

Árbol, hasta $15 \mathrm{~m}$ alt.; ramas con sección transversal angular; yemas apicales cortas, glabras. Hojas a menudo agrupadas en las puntas de las ramas; pecíolos $0,7 \times 0,30-0,35 \mathrm{~cm}$, aplanados, glabros; láminas foliares obovadas, 8,8-13,0 × 3,2-4,9 cm, glabras, con largo:ancho igual a 4:1, ápice obtuso, redondeado, base aguda, decurrente, margen ligeramente revoluto a lo largo de la lámina; nervio medio ligeramente más ancho en la mitad basal, hundido en la haz, glabro; venación broquidódroma, 9-10 pares de venas secundarias, divergentes en ángulo obtuso, curvas, ramificadas antes de alcanzar el margen, anastomosadas, uniéndose en ángulo recto hasta obtuso a la vena secundaria supradyacente, con patrón reticulado ortogonal; venación marginal formando lazos cerrados, areolas perfectamente desarrolladas, de forma angular, con o sin venillas rectilíneas dentro de la areola. Inflorescencias en panículas subterminales o axilares, hasta 14,0 cm long., más largas que las hojas adyacentes. Tépalos conspicuamente desiguales entre sí, los tres externos tan largos como la mitad de los internos, erectos, los externos cubiertos por tricomas lisos, adpresos o ascendentes, con cobertura densa en la cara abaxial, mientras que los internos presentan tricomas en ambas caras. Estambres fértiles 9; anteras del V1 y V2 ovadas, 1,5 × 0,7 mm, 2 lóculos, con dehiscencia introrsa, pubescentes en la cara abaxial, filamentos hasta 2,4 mm long., ligeramente más largos que las anteras, pubescentes; anteras del V3 triangulares, $0,9 \times 0,4 \mathrm{~mm}, 2$ lóculos, con dehiscencia extrorsa, pubescentes en la cara abaxial, filamentos hasta $2 \mathrm{~mm}$ long., dos veces más largos que las anteras, pubescentes, acompañados de un par de glándulas redondeadas, sésiles, adnadas a 1/4 de la longitud del filamento; estaminodios 3, sagitados, hasta 2,0 mm long., pubescentes; ovario y estilo glabros. Frutos obovoides, 4,5-5,5 $\mathrm{mm}$ diám., pedúnculos 2,0-3,0 mm long., no engrosados, de textura lisa; tépalos y estambres persistentes, pubescentes.
Persea cuneata ha sido colectada desde Costa Rica hasta Perú, y en Venezuela sólo ha sido colectada en el Estado Trujillo.

Se distingue por sus hojas oblanceoladas a oblongas y por las anteras fértiles siempre biloculares. Los tépalos son persistentes durante la fructificación y suelen alargarse hasta alcanzar la mitad del fruto.

Materiales examinados: VENEZUELA. TrujiLlo: Municipio Escuque, a orilla de la carretera de La Mesa de San Pedro, III-1994, S.M. Niño 115 (PORT); arriba de Escuque, entre Escuque y la Mesa de San Pedro, 20-23-II-1971, J.A. Steyermark 104629 (VEN).

8. Persea fastigiata L.E. Kopp, Mem. New York Bot. Gard. 10(5): 71. 1964. Tipo: VENEZUELA. Amazonas: Cerro Huachamacari, Río Cunucunuma, 11-XII-1950, B.M. Maguire, R.S. Cowan \& J.J. Wurdack 30130 (Holótipo NY!).

$=$ P. fastigiata var. pilosa L.E. Kopp, Mem. New York Bot. Gard. 10(5): 72. 1964. Tipo: VENEZUELA. Bolívar: Chimantá Massif, Torono-tepuí, vicinity of summit camp along Río Tirica, $1.925 \mathrm{msnm}, 3$-III1955, J. Steyermark \& J. Wurdack 1240 (Holótipo NY!).

Figuras 2E, 9B.

Árbol o arbusto, hasta 13,5 m alt.; ramas con sección transversal terete, con tricomas amarillentos, blanquecinos o parduzcos, lisos, adpresos, raras veces ascendentes o erectos, con cobertura muy laxa a densa; yemas apicales cortas, con indumento igual que las ramas. Hojas agrupadas en las puntas de las ramas; pecíolos 1,0-2,0 × 0,18-0,25 cm, acanalados o estriados longitudinalmente, generalmente con tricomas amarillentos, blanquecinos o parduzcos, lisos, adpresos, raras veces ascendentes o erectos, con cobertura muy laxa a densa, raras veces son glabras; láminas foliares elípticas hasta obovadas, 7,0-14,5 $\times 2,5-5,2 \mathrm{~cm}$, con largo:ancho igual a 2:1 o $3: 1$, raras veces hasta $4: 1$, pubescentes, ápice agudo a obtuso, a veces acuminado, base aguda u obtusa, margen ligeramente revoluto en toda la longitud de la lámina; nervio medio glabro o pubescente; venación craspedódroma a eucamptódroma, 9-14 pares de venas secundarias, divergentes en ángulo obtuso, rectas o curvas, a menudo no anastomosadas, cuando anastomosadas se unen en ángulo agudo a la vena secundaria supradyacente; venación de tercer orden con patrón percurrente convexo o ramificado; venación marginal fimbriada o formando lazos cerrados, areolas perfectamente desarrolladas, de 


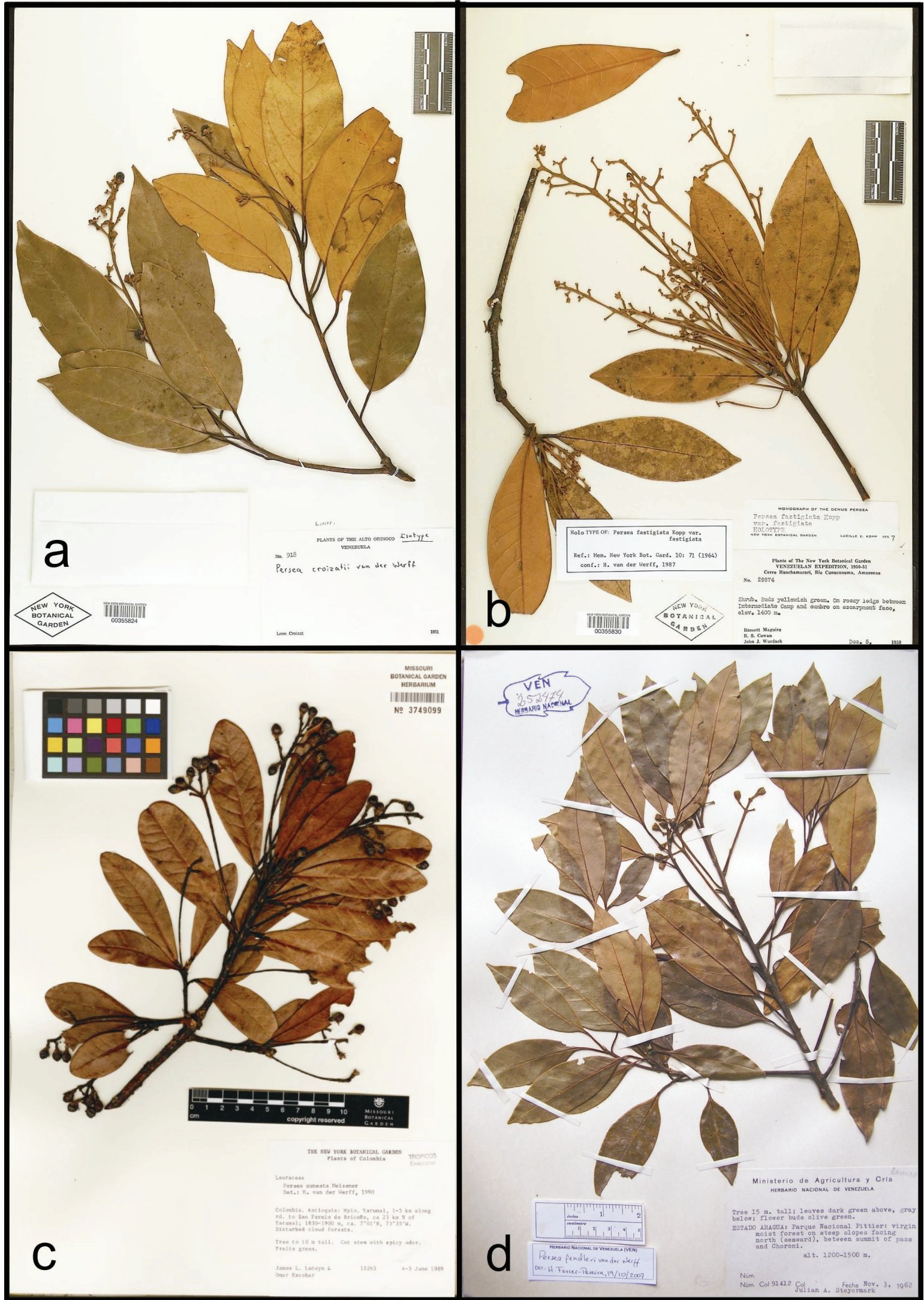

Figura 9. Imágenes de las colecciones examinadas. A. Persea croizatii. B. P. fastigiata. C. P. cuneata. D. P. fendleri.

Figure 9. Images of examined vouchers. A. Persea croizatii. B. P. fastigiata. C. P. cuneata. D. P. fendleri. 
forma redondeada, sin venillas. Inflorescencias en panículas subterminales, hasta $16,0 \mathrm{~cm}$ long., más largas que, ligeramente más largas o tan largas como las hojas adyacentes. Flores 3,5-5,0 mm long.; pedicelos 1,4-3,0 mm long. Tépalos conspicuamente desiguales entre sí, los tres externos tan largos como $1 / 2$ de los internos, erectos, los externos con tricomas lisos, adpresos, raras veces ascendentes o erectos, con cobertura muy laxa a densa en la cara abaxial, mientras que los internos son pubescentes en ambas caras. Estambres fértiles 6; anteras del V1 y V2 ovadas o trapezoidales, $0,8-1,0 \times 0,4-0,6 \mathrm{~mm}$, 4 lóculos, con dehiscencia introrsa, glabras, filamentos hasta 2,0 mm long., dos o tres veces la longitud de las anteras, pubescentes; anteras del V3 reducidas, $0,6 \times 0,4 \mathrm{~mm}$, glabras, no funcionales, filamentos hasta $2,0 \mathrm{~mm}$ long., tres veces más largos que las anteras, pubescentes, acompañados de un par de glándulas redondeadas o cordadas, sésiles, adnadas a 1/4 de la longitud del filamento; estaminodios 3, sagitados, hasta 1,5 mm long., pubescentes; ovario esférico, $1,0 \times 1,0 \mathrm{~mm}$ diám., glabro, estilo 1,2-1,8 mm long., más largo que el ovario. Frutos globosos u obovoides, 7,5-7,9 mm diám., pedúnculos 4,4-7,0 $\mathrm{mm}$ long., gradualmente engrosados hacia el receptáculo, de textura lisa; tépalos y estambres persistentes, pubescentes.

Es la especie más colectada en los estados Bolívar y Amazonas, y por extensión se ha colectado también en Brasil y Colombia. Está presente en los bosques pluviales desde 800 a $2.400 \mathrm{msnm}$, por lo cual puede diferenciarse de $P$. fluviatilis, especie emparentada por presentar seis estambres. Sus hojas oblanceoladas, coriáceas y de margen revoluto, tienen una apariencia glauca en estado natural que se transforma en un color naranja cuando se secan las hojas. Las inflorescencias alcanzan una longitud mayor o igual a la de las hojas donde nacen y las flores presentan tépalos externos mucho más cortos que los internos y seis estambres fértiles, los cuales persisten en un conjunto clamídeo que subtiende el fruto en la maduración. Los pedúnculos se ensanchan hacia el receptáculo y se tornan rojizos conforme madura el fruto. Esta especie puede ser confundida con $P$. lemensis, de la cual se distingue por la forma de las hojas y el número de estambres fértiles.

Materiales examinados: VENEZUELA. AmAZonAs: Cerro Huachamacari, Río Cunucunuma, occasional in vicinity of Summit Camp, 1.800 msnm, 6-XII-1950,
B. Maguire et al. 30019 (Isótipos de P. fastigiata var. fastigiata, VEN!, US!, F!); Cerro de la Neblina, Río Yatua, banks of Canon Grande river SSW of Cumbre Camp, 25-XII-1957, B. Maguire et al. 42497 (Parátipos, VEN, US, F); Cerro Huachamacari, Río Cunucunuma, occasional in vicinity of Summit Camp, 14-XII-1950, B. Maguire et al. 30199 (VEN, US, F, Parátipos de $P$. fastigiata). Bolívar: Valle Encantado, lado derecho del Salto Angel, Auyantepuy, 15-VIII-1968, E. Foldats 7090 (VEN).

De acuerdo con Kopp (1966) y van der Werff $(1999,2008)$ se reconocen dos variedades de esta especie por el grado de pubescencia de las hojas: Persea fastigiata var. fastigiata y $P$. fastigiata var. sericea. La primera presenta hojas oblanceoladas, comúnmente glabras, pero cuando glabrescentes, los tricomas son cortos, amarillentos o blanquecinos y a menudo se distribuyen en las venas de la cara abaxial. van der Werff (2008) considera que la variedad es endémica de Venezuela. Por el contrario, P. fastigiata var. sericea tiene hojas elípticas con pubescencia sericea formada por tricomas parduzcos que cubren toda la superficie abaxial de las hojas. A diferencia de $P$. fastigiata var. fastigiata, los estambres del V3 en la var. sericea son fértiles, tetraloculares, con los lóculos superiores reducidos. Esta variedad sólo ha sido reportada para una localidad en Venezuela (Cerro Neblina, Estado Amazonas) y en Colombia (Cerro de Circasia, Vaupés). En este trabajo se propone una variedad nueva: Persea fastigiata var. bilocularis, la cual se distingue de las anteriores por tener seis estambres fértiles, con anteras biloculares, pubescentes en el ápice.

8.1. Persea fastigiata var. fastigiata L.E. Kopp. Tipo: VENEZUELA.AMAZONAs:Cerro Huachamacari, Río Cunucunuma, occasional in vicinity of SummitCamp, 1.800 msnm, 6-XII-1950, B. Maguire et al. 30019 (Isótipos, VEN!, US!, F!).

Árbol o arbusto; ramas con tricomas amarillentos o blanquecinos, lisos, adpresos, raras veces ascendentes o erectos, con cobertura muy laxa a densa; yemas apicales cortas, con indumento igual que las ramas. Hojas agrupadas en las puntas de las ramas; láminas foliares generalmente obovadas, con largo:ancho igual a $2: 1$ o $3: 1$, raras veces hasta $4: 1$, pubescentes, margen ligeramente revoluto en toda la longitud de la lámina. Inflorescencias en panículas subterminales, generalmente más largas que las hojas adyacentes, con 
tricomas amarillentos, lisos, adpresos, generalmente con cobertura laxa. Flores 3,5-4,0 mm long.; tépalos conspicuamente desiguales entre sí, los tres externos tan largos como $1 / 2$ de los internos, erectos, los externos con tricomas lisos, adpresos, raras veces ascendentes o erectos, con cobertura muy laxa a densa en la cara abaxial, mientras que los internos son pubescentes en ambas caras. Estambres fértiles 6; anteras del V1 y V2 ovadas o trapezoidales, 4 lóculos, glabras, filamentos pubescentes; anteras del V3 reducidas, no funcionales.

8.2. Persea fastigiata var. sericea L.E. Kopp. Tipo: VENEZUELA.AmAZONAs: CerroNeblina, "Bonnetia forest at northwest head of Caño Grande. $2.000 \mathrm{~m}$ ", 8-9-XII-1957, B. Maguire et al. 42321 (Holótipo NY).

Árbol o arbusto; ramas con tricomas parduzcos, lisos, adpresos, raras veces ascendentes o erectos, con cobertura medianamente densa a densa; yemas apicales cortas, con indumento igual que las ramas. Hojas agrupadas en las puntas de las ramas; láminas foliares generalmente elípticas, raras veces obovadas, con largo:ancho hasta 4:1, pubescentes, margen revoluto en toda la longitud de la lámina. Inflorescencias en panículas subterminales, generalmente más largas que las hojas adyacentes, con tricomas parduzcos, lisos, adpresos, generalmente con cobertura densa. Flores hasta 5,0 mm long.; tépalos conspicuamente desiguales entre sí, los tres externos tan largos como $1 / 2$ de los internos, erectos, los externos con tricomas lisos, adpresos, raras veces ascendentes o erectos, con cobertura densa en la cara abaxial, mientras que los internos son pubescentes en ambas caras. Estambres fértiles 6; anteras del V1 y V2 ovadas o trapezoidales, 4 lóculos, pubescentes, filamentos pubescentes; anteras del V3, 4 lóculos, los lóculos superiores reducidos y los dos inferiores aparentemente funcionales, latrorsos.

\subsection{Persea fastigiata L.E. Kopp var. bilocularis}

H. Ferrer var. nov. Tipo: VENEZUELA. AMAZONAS: Departamento Río Negro, Camp III, Neblina and massif, NW Plateau (arm) $13.5 \mathrm{~km}$ ENE of Cerro de la Neblina Base Camp, 1.750-1.850 msnm, 16-18-II-1984, R. Liesner 16038 (Holótipo VEN; Isótipo F).

Figura 10

Persea fastigiata var. bilocularis diversa: antheris fertilibus ovatis, apice apiculatis, bilocularibus, antheris abaxialiter trichomantibus ferrugineis praesentibus; staminibus verticilli III infertilibus filamentis glabris, glandulis basalibus absentibus, antheris reductis.

Árbol 2,5 m alt.; ramas con sección transversal terete, cubiertas con tricomas parduzcos, lisos, adpresos con cobertura medianamente densa; yemas apicales cortas, con indumento igual que las ramas. Hojas distribuidas a lo largo de las ramas; pecíolos 2,0-2,2 ×0,23 cm, acanalados, pubescentes; láminas foliares elípticas, 11,5-13,2 × 3,5-4,1 cm, con largo:ancho igual a 3:1, ápice agudo, base aguda, cuneada, margen ligeramente revoluto en la base o en toda la longitud de la lámina, con tricomas parduzcos, lisos, adpresos con cobertura medianamente densa en la cara abaxial; nervio medio glabro o pubescente; venación eucamptódroma, 12 pares de venas secundarias, divergentes en ángulo obtuso, curvas, con patrón percurrente cóncavo; areolas no visibles. Inflorescencias en racimos o panículas axilares, hasta $18,0 \mathrm{~cm}$ long., más largas que las hojas adyacentes. Flores 4,0-4,5 mm long.; pedicelos 0,15-0,25 cm long. Tépalos conspicuamente desiguales entre sí, los tres externos tan largos como $1 / 2$ a $1 / 3$ de los internos, patentes, los externos cubiertos por tricomas parduzcos, lisos, adpresos, con cobertura medianamente densa en la cara abaxial, mientras que los internos presentan tricomas en ambas caras. Estambres fértiles 6; anteras del V1 y V2 ovadas, 1,3 × 0,5 mm, 2 lóculos, con dehiscencia introrsa, pubescentes en el ápice de las anteras, filamentos hasta 0,5 mm long., más cortos que la mitad de las anteras o ligeramente más largos que las anteras, pubescentes; los estambres de V3 presentan anteras completamente reducidas y filamentos ensanchado en la base, glabros, glándulas ausentes; estaminodios 3, sagitados, hasta $2,2 \mathrm{~mm}$ long., glabros, a veces pubescentes. Frutos globosos, pedúnculos no engrosados, de textura lisa; tépalos y estambres persistentes, pubescentes.

En esta variedad, los estambres del V3 son infértiles, con anteras reducidas, filamentos completamente glabros y sin glándulas, ensanchados en la base envolviendo ligeramente el ovario. Las anteras en V1 y V2 son biloculares y presentan un indumento característico. Kopp (1966) reportó una variación similar en el número de lóculos fértiles en V3 para $P$. urbaniana Mez, una especie caribeña que también pertenece a la sección Hexanthera. 
Clave para la determinación de las variedades de $P$. fastigiata presentes en Venezuela

1. Anteras de V1 y V2 4-loculares, glabras o con tricomas erectos, cortos, amarillentos, en toda la extensión

2. Anteras de V3 completamente reducidas ....... 8.1. P. fastigiata var. fastigiata

2. Anteras de V3 sólo con lóculos superiores reducidos, los lóculos inferiores son funcionales

8.2. P. fastigiata var.

sericea

1. Anteras de V1 y V2 2-loculares, con tricomas erectos, ferrugíneos, alargados, agrupados en el ápice de la antera 8.3. P. fastigiata var. bilocularis

9. Persea fendleri van der Werff, Novon 4(1): 72. 1994. Tipo: Venezuela. Aragua: Parque Nacional Pittier,1.200-1.500 msnm, 3-XI-1963, J. Steyermark 91412 (Holótipo NY!, Isótipo VEN!). Figura 9D.

Árbol; ramas con sección transversal angular, con tricomas amarillentos hasta blanquecinos, lisos, adpresos hasta ascendentes con cobertura medianamente densa; yemas apicales alargadas, con indumento igual que las ramas. Hojas distribuidas a lo largo de las ramas; pecíolos 2,5 × 0,10-0,18 cm, acanalados, pubescentes; láminas foliares elípticas, 8,3-10,7 $\times 2,4-4,2 \mathrm{~cm}$, con largo:ancho igual a
2:1 a 3:1, ápice agudo u obtuso, acuminado, base aguda, decurrente, margen ligeramente revoluto en la base de la lámina, con tricomas amarillentos hasta blanquecinos, lisos, adpresos hasta ascendentes con cobertura medianamente densa en la cara abaxial; nervio medio ligeramente más ancho en la mitad basal, hundido en la haz, glabro; venación broquidódroma o eucamptódroma, 7-10 pares de venas secundarias, divergentes en ángulo recto $\mathrm{u}$ obtuso, curvas, ramificadas antes de alcanzar el margen, anastomosadas, o cerrándose por arcos secundarios formados por venas de $3^{\circ}$ y $4^{\circ}$ orden, con patrón reticulado aleatorio; venación marginal formando lazos cerrados, areolas perfectamente desarrolladas, de forma angular, sin venillas. Inflorescencias en racimos o panículas axilares o subterminales, hasta $16,0 \mathrm{~cm}$ long., alcanzando $1 / 2$ o $1 / 4$ o menos de la longitud de las hojas adyacentes. Flores 3,5-5 × 3,0 mm, pedicelos de 2,0-4,0 mm long., engrosados hacia el receptáculo. Tépalos iguales a subiguales entre sí, erectos, con tricomas amarillentos hasta blanquecinos, lisos, adpresos hasta ascendentes, con cobertura medianamente densa en ambas caras de ambos verticilos. Estambres fértiles 9; anteras de V1 y V2 ovadas, $0,8 \times 0,6 \mathrm{~mm}, 4$ lóculos, con dehiscencia introrsa, glabras, filamentos hasta 1,2 $\mathrm{mm}$ long., ligeramente más largos que las anteras, pubescentes; anteras del V3 oblongas, $0,6 \times 0,4 \mathrm{~mm}, 4$ lóculos, con dehiscencia latrorsa, glabras, filamentos hasta $1,0 \mathrm{~mm}$ long., de igual longitud que las anteras, pubescentes, acompañados de un par de glándulas,

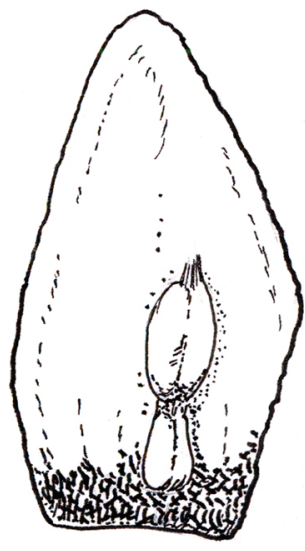

a

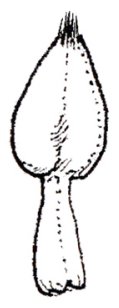

b

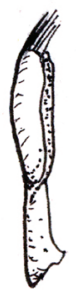

C

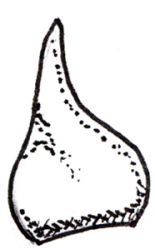

d

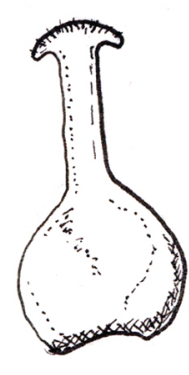

e

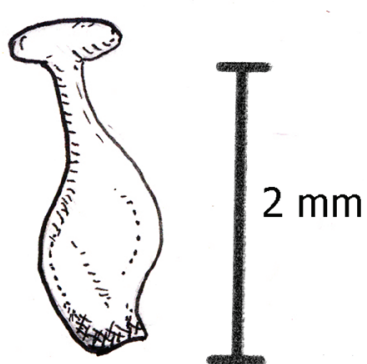

f

Figura 10. Detalles de Persea fastigiata var. bilocularis. A. Tépalo interno con estambre de V2. B. Estambre de V1 (vista frontal). C. Estambre de V2 (vista lateral). D. Estaminodio. E. Estambre con anteras reducidas, V3. F. Gineceo.

Figure 10. Details of Persea fastigiata var. bilocularis. A. Inner tepal with stamen of V2. B. Stamen of V1 (frontal view). C. Stamen of V2 (side view). D. Staminode. E. Stamen with reduced anther, V3. F. Gynaeceum. 
redondeadas, brevemente estipitadas, adnadas a $1 / 4$ de la longitud del filamento; estaminodios 3, sagitados, hasta 1,2 mm long., pubescentes; ovario ovado, 1,2 $\times 1,0 \mathrm{~mm}$, glabro, estilo 1,0 $\mathrm{mm}$ long., igual longitud que el ovario. Frutos globosos o deprimido-globosos, 12,0-14,0 mm diám.; pedúnculos 4,5-5,0 mm long., no engrosados, de textura lisa; tépalos y estambres persistentes, pubescentes.

Esta espécie se considera endémica del tramo central de la Cordillera de la Costa de Venezuela y presenta pocas colecciones en los herbarios venezolanos. Se reconoce por las hojas cortas, de textura cartácea y generalmente agrupadas cerca de los extremos de las ramas, e inflorescencias cortas con flores pequeñas (2,5 a 3,0 $\mathrm{mm}$ de longitud), pubescentes.

Van der Werff (2002) considera que este taxón pertenece a un grupo pequeño de especies de Persea caracterizado por tépalos erectos, subiguales, pubescentes en ambas caras y persistentes durante el período de fructificación, con ramas laterales naciendo de manera alterna. Persea areolatocostae resulta muy similar a $P$. fendleri por la apariencia inconspicua de ambas; sin embargo, esta última puede diferenciarse por el tamaño de las flores (2,5-3,0 mm de longitud), la presencia de un par de glándulas estipitadas cerca de la base de cada estambre del tercer verticilo y su distribución restringida al norte del Orinoco.

Materiales examinados: VENEZUELA. Aragua: Prope coloniam Tovar legit, 1854-5, A. Fendler 1096 (Parátipos K, HUH); along road to Puerto Maya, $0.5-4 \mathrm{~km}$ of its junction with La Victoria-Colonia Tovar highway, 14-I-1982, J. Luteyn et al. 8326 (Parátipos VEN, PORT, F).

10. Persea ferruginea Kunth, Nov. Gen. Sp. 2: 159.

1817. Tipo: ECUADOR. Loja: Humboldt \&

Bonpland s.n. (Fragmento en P, fototipo!).

Figuras 1G, 2I.

Arbusto, raras veces árbol, hasta $6 \mathrm{~m}$ alt.; ramas con sección transversal angular, con tricomas ferrugíneos o parduzcos, fuertemente ondulados, erectos, raras veces ascendentes o adpresos, en toda la extensión, con cobertura medianamente densa o densa; yemas apicales cortas, con indumento igual que las ramas. Hojas distribuidas a lo largo de las ramas o agrupadas en las puntas de las ramas; pecíolos $0,55-1,0 \times 0,1-0,28 \mathrm{~cm}$, aplanados hasta anchamente acanalados, pubescentes, raras veces las hojas son glabras; láminas foliares ovadas o elípticas,
$3,0-7,5 \times 2,1-5,0 \mathrm{~cm}$, con largo:ancho igual a $1: 1 \mathrm{a}$ $2: 1$, cubiertas por tricomas parduzcos a ferrugíneos, fuertemente ondulados, erectos, rara vez ascendentes o adpresos, con cobertura medianamente densa a densa en la cara abaxial, ápice agudo u obtuso, acuminado o redondeado, base obtusa, ligeramente cordada o cuneada, margen entero; nervio medio más ancho en la mitad basal, a menudo glabro, rara vez pubescente; venación broquidódroma, rara vez eucamptódroma, 5-7 pares de venas secundarias, divergentes en ángulo agudo hasta obtuso, curvas, ramificadas antes de alcanzar el margen, anastomosadas, uniéndose en ángulo agudo, raras veces recto u obtuso, a la vena secundaria supradyacente o cerrándose por arcos secundarios formados por venas de $3^{\circ}$ y $4^{\circ}$ orden, con patrón reticulado ortogonal; venación marginal formando lazos cerrados, areolas poco visibles, perfectamente desarrolladas, de forma angular, con venillas simples o ramificadas. Inflorescencias de apariencia corimbiforme, subterminales o axilares, hasta 9,0 cm long., alcanzando $1 / 2$ de la longitud o más largas que las hojas adyacentes. Flores $3,0-8,0 \times 3,4 \mathrm{~mm}$, pedicelos 2,0-3,8 $\mathrm{mm}$ long. Tépalos conspicuamente desiguales entre sí, los tres externos tan largos como $1 / 2$ a $1 / 3$ de los internos, erectos, los externos con tricomas fuertemente ondulados, ascendentes o erectos, de cobertura medianamente densa a densa sólo en la cara abaxial, mientras que los internos presentan tricomas que cubren ambas caras. Estambres fértiles 9; anteras del V1 y V2 ovadas o trapezoidales, $0,8-1,3 \times 0,6-0,8 \mathrm{~mm}, 4$ lóculos, con dehiscencia introrsa, glabras, filamentos hasta 0,9-1,3 mm long., de igual longitud o ligeramente más largos que las anteras, pubescentes; anteras del V3 rectangulares, 0,6-1,3 × 0,2-0,45 mm, 4 lóculos, con dehiscencia latrorsa, glabras, filamentos hasta 0,7-1,5 mm long., de igual longitud o ligeramente más largos que las anteras, pubescentes, acompañados de un par de glándulas, cordadas, sésiles, adnadas a 1/4 de la longitud del filamento; estaminodios 3, sagitados, hasta 1,0-1,5 mm long., pubescentes; ovario esférico a elipsoidal, 1,3-1,4 × 1,0 mm, glabro, estilo $1,8 \mathrm{~mm}$ long., más largo que el ovario. Frutos globosos, 10,0 mm diám.; pedúnculos 3,0-4,0 mm long., raras veces engrosados hacia el receptáculo de textura lisa; tépalos y estambres persistentes, pubescentes.

Persea ferruginea es una especie andina que habita en Colombia, Ecuador, Perú y Venezuela. En Venezuela ha sido comúnmente colectada en los 
páramos y bosques aledaños en los estados Lara, Mérida, Trujillo y Táchira, entre 2.500 y 3.300 msnm. Es una de las especies que alcanza mayor altitud en su distribución geográfica.

Se caracteriza por tener hojas anchamente ovadas, con base truncada hasta ligeramente cordada, ápice agudo u obtuso, coriáceas y bastante rígidas, siempre glabras en la cara adaxial y densamente cubierta por tricomas erectos y torcidos en la abaxial. Los nervios son prominentes por debajo de las hojas y forman un retículo conspicuo, que resulta diagnóstico para la especie. Las inflorescencias son subterminales, corimbiformes, glabras. Las flores están cubiertas de tricomas y tienen tépalos desiguales, que se tornan patentes y endurecidos durante la fructificación. Los frutos son elipsoides a globosos, de 7,0 a 9,0 $\mathrm{mm}$ de diámetro.

Este taxón es muy semejante morfológicamente a otros taxones de la sección Mutisaea: P. ruizii y $P$. corymbosa, de las cuales resulta complicado distinguir. No obstante, algunos caracteres pueden ser utilizados para la determinación de $P$. ferruginea como el tamaño de los frutos, el retículo conspicuo en el envés de las hojas y la forma y distribución de los tricomas. La información disponible para los taxones antes mencionados es reducida y se requieren mayor cantidad de colecciones para determinar la circunscripción de los mismos.

Materiales examinados: VENEZUELA. LARA: Distritos Morán y Carache, páramos de El Jabón-El Turmal, a uno y otro del filo o cresta que representa el límite entre ambos estados, en dirección hacia el páramo de Cendé, unos $15 \mathrm{~km}$ a $\mathrm{E}$ de la población de Carache, 1-2-X-1970, L. Ruíz-Terán \& M. López Figueiras 940 (MERF). TÁCHIRA: de civitate La Grita ad civitatem Pregonero, per iter et nemora montana, 19-IX-1965, Bernardi 10958 (US, K). TruJILlo: Distrito Carache, above Mesa Arriba, between Pico de Jabón \& Páramo de Turmal, SE of Laguna de Turmal, $12 \mathrm{~km}$ SE of Carache, 12-V-1998, L.J. Dorr \& L.C. Barnett 5130 (VEN, MY, MER, PORT).

11. Persea fluviatilis van der Werff, Ann. Missouri Bot. Gard. 76(2): 474. 1989. Tipo: VENEZUELA. Amazonas: Departamento Río Negro, lower part of Río Baria, 80 msnm, 22-23-VII-1984, G. Davidse 27717 (Holótipo MO, Isótipo VEN!).

Figuras 1D, 11B.

Árbol, 6-10 m alt., 15 cm DAP; ramas con sección transversal angular, huecas, cubiertas por tricomas amarillentos, a veces parduzcos, lisos, ascendentes, con cobertura medianamente densa a densa; yemas apicales cortas, con indumento igual que las ramas. Hojas distribuidas a lo largo de las ramas; pecíolos 2,6-3,1 × 0,17-0,29 cm, acanalados o estriados longitudinalmente, pubescentes, raras veces glabros; láminas foliares elípticas, 11,2-22,2 ×3,2-6,4 cm, con largo:ancho igual a 3:1 a 4:1, ápice agudo, acuminado, a menudo base aguda, desigual, margen ligeramente revoluto en la base de la lámina o en toda la longitud, con tricomas amarillentos, a veces parduzcos, lisos, ascendentes, con cobertura medianamente densa a densa; nervio medio pubescente; venación broquidódroma o eucamptódroma, 7-13 pares de venas secundarias, divergentes en ángulo recto hasta obtuso, curvas, a menudo ramificadas antes de alcanzar el margen, anastomosadas, cerrándose por arcos secundarios formados por venas de $3^{\circ} \mathrm{y} 4^{\circ}$ orden, con patrón percurrente recto o convexo; venación marginal formando lazos cerrados o fimbriada, areolas ausentes. Inflorescencias en racimos subterminales o axilares, hasta 2,5-7,6 cm long., alcanzando 1/4 o menos de la longitud de las hojas adyacentes. Flores 3,8-4,5 mm long.; pedicelos 1,5-2,0 mm long. Tépalos conspicuamente desiguales entre sí, los tres externos tan largos como 1/2 a 1/3 de los internos, erectos, los externos cubiertos por tricomas amarillentos, a veces parduzcos, ondulados, ascendentes, con cobertura densa en la cara abaxial, mientras que los internos son pubescentes en ambas caras. Estambres fértiles 6; anteras del V1 y V2 ovadas, 1,0 × 0,75 mm, 4 lóculos, con dehiscencia introrsa, pubescentes, filamentos hasta 1,4 mm long., ligeramente más largos que las anteras, pubescentes; anteras del V3 reducidas, filamentos hasta $1,5 \mathrm{~mm}$ long., hasta tres veces más largos que las anteras, pubescentes, acompañados de un par de glándulas redondeadas, sésiles, adnadas a 1/4 de la longitud del filamento; estaminodios 3, sagitados, hasta 1,2 mm long., pubescentes; ovario esférico, ligeramente deprimido en el ápice, 0,7 $\times 0,9 \mathrm{~mm}$, glabro, estilo $2,8 \mathrm{~mm}$ long., más largo que el ovario. Frutos globosos a obovoides, 9,5-9,7 mm diám., pedúnculos 5,5-6,0 mm long., gradualmente engrosados hacia el receptáculo, de textura lisa; tépalos y estambres persistentes, pubescentes.

Este taxón ha sido colectado en los bosques periódicamente inundados de las tierras bajas del Estado Amazonas, distribuyéndose en altitudes de 80 a 150 msnm. Presenta tallos huecos, con hojas lanceoladas a estrechamente elípticas, de hasta $25,0 \mathrm{~cm}$ de longitud, completamente glabras. Las 


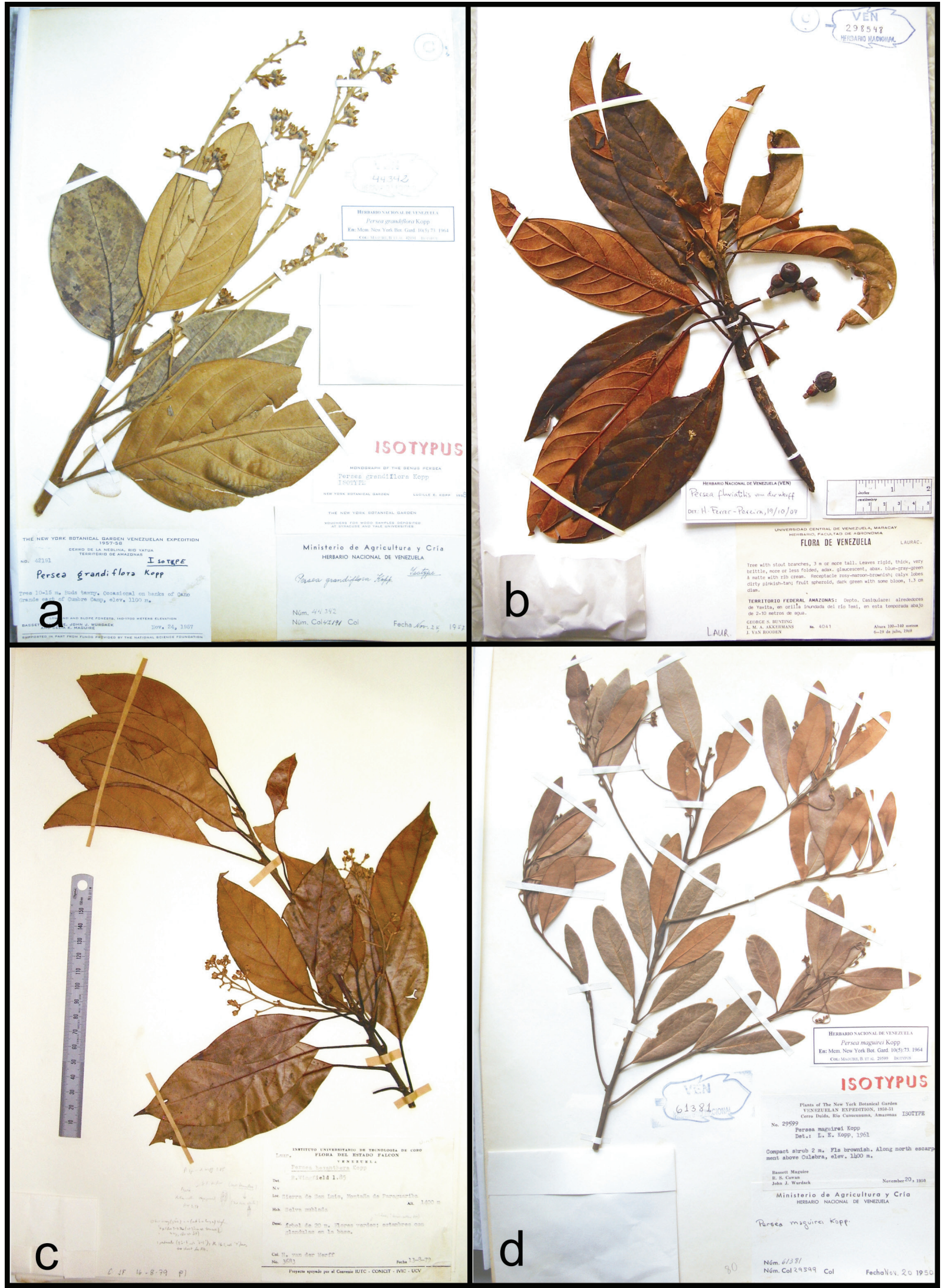

Figura 11. Imágenes de las colecciones examinadas. A. Persea grandiflora. B. P. fluviatilis. C. P. hexanthera. D. P. maguirei. Figure 11. Images of examined vouchers. A. Persea grandiflora. B. P. fluviatilis. C. P. hexanthera. D. P. maguirei. 
inflorescencias de esta especie son más bien reducidas, por lo que apenas alcanzan la mitad de la longitud de las hojas; los tépalos son subiguales, ya que la diferencia entre ambos verticilos es menos notoria que en otros taxones; y los estambres del verticilo III están reducidos a estaminodios, por lo que se ha considerado afín a las especies de la sección Hexanthera. No obstante, existen pocas colecciones de esa especie para determinar la estabilidad de algunos caracteres observados como la apariencia de las infrutescencias en estado maduro. Van der Werff (1999) sostiene que $P$. fluviatilis es afín con $P$. meridensis por las características de sus hojas y la presencia de seis estambres fértiles; sin embargo, ambos taxones son poco conocidos y dichas afinidades no han sido confirmadas. Mas aún, la especie posiblemente más afín a la anterior, sería $P$. pseudofasciculata con la cual comparte mayor número de características morfológicas y ecológicas.

Materiales examinados: VENEZUELA. AmAZonAs: Departamento Casiquiare, alrededores de Yavita, en orilla inundada del Río Temí, 6-19-VII-1969, G. Bunting et al. 4041 (Parátipos MY, VEN); Departamento Casiquiare, alrededores de Yavita (vía Temi) y cerca de la carretera Yavita-Pimichín hasta el km 5 hacia Pimichin, 6-19-VII-1969, G. Bunting et al. 4050 (Parátipos MY, VEN); márgenes pobladas del Río Temí, Yavita, Alto Orinoco, 1941, L. Williams 14122 (Parátipos VEN, F).

12. Persea grandiflora L.E. Kopp, Mem. New York Bot. Gard. 10(5): 73. 1964. Tipo: VENEZUELA.

Amazonas: Cerro de La Neblina, Río Yatua, on banks of Caño Grande, E of Cumbre Camp, 1.100 msnm, 24-XI-1957, B. Maguire, J. Wurdack \& C. Maguire 42191 (Holótipo NY!, Isótipo VEN!).

Figuras $2 \mathrm{~K}, 11 \mathrm{~A}$.

Árbol, 10-15 m alt.; ramas con sección transversal angular, con tricomas amarillentos, ondulados, erectos, raras veces ascendentes, con cobertura medianamente densa a densa; yemas apicales cortas, con indumento igual que las ramas. Hojas distribuidas a lo largo de las ramas; pecíolos $2,5-4,0 \times 0,28-0,33 \mathrm{~cm}$, estriados longitudinalmente, pubescentes; láminas foliares ovadas o elípticas, $11,0-17,0 \times 5,0-11,0 \mathrm{~cm}$, con largo:ancho igual a 1:1 a 2:1, ápice obtuso, acuminado, base obtusa, desigual, margen ligeramente revoluto en toda la longitud de la lámina, con tricomas amarillentos, ondulados, erectos, raras veces ascendentes, con cobertura densa; nervio medio ligeramente más ancho en la mitad basal, hundido en la haz, densamente pubescente; venación eucamptódroma, 6-8 pares de venas secundarias, divergentes en ángulo recto hasta obtuso, curvas, raras veces ramificadas antes de alcanzar el margen, con patrón percurrente recto o recurvo; areolas no visibles. Inflorescencias en racimos o panículas subterminales o axilares, hasta 27,6 cm long., dos veces más largas que las hojas adyacentes. Flores 8,0-10,0 mm long.; pedicelos 1,0-2,0 $\mathrm{mm}$ long. Tépalos conspicuamente desiguales entre sí, los tres externos tan largos como $1 / 3$ de los internos, patentes, los externos pubescentes en la cara abaxial, mientras que los internos presentan tricomas en ambas caras. Estambres fértiles 9; anteras del V1 y V2 oblongas, 1,5 mm long., 4 lóculos, con dehiscencia introrsa, pubescentes; filamentos hasta 3 veces más largos que las anteras, pubescentes; anteras del V3 rectangulares, 4 lóculos, con dehiscencia latrorsa, glabras, tres veces más largos que las anteras, pubescentes, acompañados de un par de glándulas cordadas, sésiles, adnadas a $1 / 4$ de la longitud del filamento; estaminodios 3, sagitados, pubescentes; ovario globoso a deprimido-globoso, cubierto de tricomas ondulados, adpresos con cobertura densa; estilo de igual longitud que el ovario, pubescente. Frutos obovoides, 9,0 $\mathrm{mm}$ diám., pedúnculos 3,5 mm long., no engrosados, de textura lisa; tépalos y estambres persistentes en el fruto, pubescentes.

Persea grandiflora sólo ha sido reportada para Venezuela, en los estados Amazonas y Bolívar. Es la especie del género con las flores de mayor tamaño reportadas hasta ahora (9,0-10,0 mm long.). Sus hojas son anchamente ovadas, cubiertas de tricomas lisos, adpresos, amarillentos en la cara abaxial, y las inflorescencias siempre son más largas que el doble de la longitud de las hojas que las sostienen. Estos caracteres resultan esenciales para diferenciarla de $P$. perseiphylla y $P$. fastigiata. Es de hacer notar que en esta especie, el ovario está cubierto de tricomas, lo cual permite asignarla en la sección Aurataea.

Materiales examinados: VENEZUELA. AmAZonAs: Cerro de La Neblina, Río Yatua, just S of Camp 3, 31-XII-1957, B. Maguire et al. 42557 (Parátipo VEN). Bolívar: Meseta del Jaua, Cerro Sarisariñama: Cumbre, porción nor-este, 16-18-II-1974, J. Steyermark et al. 109165 (VEN).

13. Persea hexanthera L.E. Kopp, Mem. New York Bot. Gard. 14(1): 86. 1966. Tipo: PERÚ. HuANuCO: Huamalies, 2.000-2.500 msnm. Weberbauer 3525 (Holótipo B!).

Figuras 2L, 11C. 
Árbol, 4-20 m alt.; ramas con sección transversal angular, con tricomas amarillentos, lisos, adpresos, con cobertura laxa a muy laxa; yemas apicales cortas, con indumento igual que las ramas, o glabras. Hojas frecuentemente agrupadas en las puntas de las ramas o distribuidas a lo largo de las ramas; pecíolos 2,5-4,2 $\times 0,14-0,25 \mathrm{~cm}$, acanalados, cubiertos por tricomas amarillentos, ondulados, ascendentes, con cobertura medianamente densa, raras veces glabros; láminas foliares elípticas, 9,7-18,0 × 3,2-7,3 cm, con largo:ancho igual a $2: 1$ a $3: 1$, hasta $4: 1$, con tricomas amarillentos, ondulados, ascendentes, con cobertura medianamente densa en la cara abaxial, ápice agudo, acuminado, base aguda o obtusa, cuneada, margen ligeramente revoluto, en toda la longitud de la lámina; nervio medio hundido en la haz, pubescente, raras veces glabro; venación eucamptódroma, 6-8 pares de venas secundarias, divergentes en ángulo hasta obtuso, curvas, a menudo ramificadas antes de alcanzar el margen, anastomosadas, cerrándose por arcos secundarios formados por venas de $3^{\circ}$ y $4^{\circ}$ orden, con patrón percurrente recto hasta convexo; venación marginal fimbriada, areolas perfectamente desarrolladas, de forma angular, con venillas rectilíneas dentro de la areola. Inflorescencias en racimos o panículas subterminales o axilares, hasta $10,0 \mathrm{~cm}$ long., alcanzando $1 / 4$ hasta $3 / 4$ de la longitud de las hojas adyacentes. Flores $3,5 \mathrm{~mm}$ long.; pedicelos 2,5 $\mathrm{mm}$ long. Tépalos conspicuamente desiguales entre sí, los tres externos tan largos como $1 / 2$ de los internos, erectos, los externos con tricomas amarillentos, ondulados, ascendentes, con cobertura medianamente densa en la cara abaxial, mientras que los internos son pubescentes en ambas caras. Estambres fértiles 6; anteras de V1 y V2 oblongas, 1,8 mm de long., 4 lóculos, con dehiscencia introrsa, glabras, filamentos de igual longitud que las anteras; anteras de V3 reducidas, filamentos hasta $5,5 \mathrm{~mm}$ long., pubescentes, acompañados de un par de glándulas redondeadas, sésiles, adnadas a $1 / 4$ de la longitud del filamento; estaminodios 3, sagitados, pubescentes; ovario obovoide a deprimido-globoso, $2,3 \mathrm{~mm}$ long., glabro, estilo de igual longitud o ligeramente más largo que el ovario. Frutos globosos o obovoides, 8,8-10,0 mm diám.; pedúnculos $5,0 \mathrm{~mm}$ long., gradualmente engrosados hacia el receptáculo, de textura lisa; tépalos y estambres persistentes, pubescentes.

Esta especie se ha colectado Colombia, Ecuador, Perú y Venezuela. En éste último se le ha reportado en los bosques nublados de la Cordillera de la Costa, principalmente.
Tiene hojas elípticas, coríaceas, con ápice y base agudos, glabras en la cara adaxial y glabrescentes en la abaxial con margen ligeramente revoluto en toda la extensión de la lámina, así como pecíolos canaliculados de 2,1 a 4,2 cm de longitud. Las inflorescencias son más largas que las hojas que las sostienen y las flores llegan a medir hasta $8,5 \mathrm{~mm}$ de longitud. Está emparentada cercanamente con $P$. meridensis, de la cual difiere en la forma de las hojas e inflorescencias y el indumento. Existen pocas colecciones en flor y/o fruto depositadas en los herbarios venezolanos, lo cual dificulta su estudio.

Materiales examinados: VENEZUELA. Aragua: Parque Nacional Henri Pittier, Cumbre de Rancho Grande, 21-V-2006, D. Conde et al. 178 (MY). Miranda: selvas pluviales de Guatopo, 15-XI-1956, A.L. Bernardi 5728 (MER). Falcón: Sierra de San Luis, Montaña de Paraguariba, 13-VIII-1979, H. van der Werff 3683 (VEN, CORO).

14. Persea jenmanii Mez, Jahrb. Königl. Bot. Gart. Berlin 5. 1889. Tipo: GUYANA. In campestribus Guyanae anglicae ad flumen Potaro, Jenman 864 (Holótipo K!).

Figura $3 \mathrm{H}$.

Árbol, 1,6-20 m alt., 20,0 cm DAP; ramas y tallo aromáticos con sección transversal terete o angular, cubiertas por tricomas ferrugíneos o parduzcos, fuertemente ondulados, erectos, con cobertura densa; yemas apicales cortas, con indumento igual que las ramas. Hojas distribuidas a lo largo de las ramas, pecíolos 1,0-3,0 ×0,16 cm, acanalados o estriados longitudinalmente, densamente pubescentes; láminas foliares elípticas, raras veces ovadas u obovadas, $7,2-15,5 \times 3,7-6,5 \mathrm{~cm}$, con largo:ancho igual a $2: 1$, con tricomas ferrugíneos o parduzcos, fuertemente ondulados, erectos, con cobertura densa en la cara adaxial, ápice obtuso, a veces agudo, redondeado o acuminado, base aguda u obtusa, cuneada, margen ligeramente revoluto en la base de la lámina, raras veces en toda la longitud de la lámina; nervio medio ligeramente más ancho en la mitad basal, hundido en la haz, pubescente, raras veces glabro; venación eucamptódroma, 5-8 pares de venas secundarias, divergentes en ángulo recto hasta obtuso, curvas, a menudo ramificadas antes de alcanzar el margen, raras veces anastomosadas, con patrón percurrente recto o recurvo; venación marginal formando lazos cerrados, areolas no visibles. Inflorescencias en racimos o panículas subterminales o axilares, hasta 
26,6 cm long., a menudo dos veces más largas que las hojas adyacentes. Flores 4,5-7,0 mm long.; pedicelos 1,0-4,0 $\mathrm{mm}$ long. Tépalos conspicuamente desiguales entre sí, los tres externos tan largos como $1 / 2$ a $1 / 3$ de los internos, erectos, los externos cubiertos por tricomas ferrugíneos o parduzcos, fuertemente ondulados, erectos, con cobertura densa en la cara abaxial, mientras que los internos presentan tricomas en ambas caras. Estambres fértiles 9; anteras del V1 y V2 trapezoidales, 0,6-0,8 × 0,6-0,8 mm, 4 lóculos, con dehiscencia introrsa, glabras, filamentos hasta 2,0 mm long., dos veces la longitud de las anteras, laxamente pubescentes; anteras del $\mathrm{V} 3$ rectangulares, 0,5-0,7 × 0,4 mm, 4 lóculos, con dehiscencia latrorsa, glabras, filamentos hasta $2,2 \mathrm{~mm}$ long., tres veces o más largos que las anteras, laxamente pubescentes, acompañados de un par de glándulas, cordadas, estipitadas, adnadas a 1/4 de la longitud del filamento; estaminodios 3, sagitados, hasta 1,5 mm long., laxamente pubescentes; ovario deprimido-globoso, $1,7 \times 2,0 \mathrm{~mm}$, glabro, estilo $1,7 \mathrm{~mm}$ long., igual longitud que el ovario. Frutos globosos u obovoides, 5,0-6,0 mm diám., pedúnculos 3,0-5,0 mm long., no engrosados, de textura lisa; tépalos y estambres persistentes, pubescentes.

Persea jenmanii es una especie que ocurre en Brasil y Venezuela. Ha sido colectado al sur del Orinoco, generalmente en los bordes y dentro de los bosques pluviales por encima de $550 \mathrm{msnm}$ en Amazonas y de 900 msnm en Bolívar.

Se distingue rápidamente por las características y distribución del indumento en la planta, generalmente conformado por tricomas torcidos, erectos de color ferrugíneo en las partes nuevas, que se tornan grisáceos y caducos en las zonas adultas. Las hojas son ovadas hasta anchamente elípticas, rígidas, glabras en la superficie adaxial y pubescentes en la abaxial, con venas secundarias curvas, prominentes en el envés. Las inflorescencias alcanzan hasta tres veces la longitud de las hojas y siempre son pubescentes así como los tépalos. Conjuntamente con $P$. grandiflora, $P$. maguirei y $P$. perseiphylla, forma un grupo de especies guayanesas con indumento denso cubriendo el envés de las hojas, inflorescencias y tépalos. Puede ser diferenciada claramente porque los tricomas siempre son torcidos, mientras que en las anteriores son estrictamente lisos.

Materiales examinados: VENEZUELA. AmAZonAs: summit of Cerro Duida Savanna Hills, 2-IX-1944, J.A. Steyermark 58259 (HUH, F). BoLÍvAR: Municipio
Gran Sabana, Sierra Lema, La Escalera, frente a la alcabala de Lema, 12-13-VI-2006, E. Sanoja et al. 7893 (VEN).

15. Persea lemensis H. Ferrer \& Sanoja sp. nov. Tipo: VENEZUELA. BoLívaR: en el drenaje del Río Cuyuní, a lo largo del Río Anawaray-Parú, vecindades del Km 134, al Sur de El Dorado, 1.300-1.350 msnm, 25-XII-1970, J. Steyermark, G.C.K.\& E.Dunsterville 104427 (Holótipo VEN!).

Figuras 1C, 2H, 3C, 3D, 12.

Arbor 5-15 metralis. Petioli canaliculati, glabri. Folia elliptica, apice obtusa, interdum acuta, e rotundato acuminata, margine parum revoluta, glabra; venis secundariis brochidodromis vel eucamptodromis, utrinque 6-10, saepe propem marginem ramosis, anastomosantibus, tertiariis percurrentibus, rectis; areolis perfecte formatis, angulatis vel rotundatis, venulis ausentibus. Inflorescentiae subterminaliis. Flores 6-6,2 $\mathrm{mm}$ longi. Tepala inaequalia, tria exteriora 1/3-1/4 interiorum aequantia, erecta, extus tantum pubescentia, interiora extus intrusque pubescentia. Stamina fertilia 9; antherae V1 et V2 oblongae vel trapezoidales, 4 loculis praeditae, introrsae, glabrae, filamentis antheras duplo triplove superantibus, pubescentibus, antherae V3 oblongae, 4 loculis praeditae, laterales, labrae, filamentis pubescentibus, binis glandulis rotundatis vel quadrangulatis, sessilibus, ad 1/4 filamenti praesentibus; staminodia 3, sagittata, trichomantibus adpressis vel adscendentibus; ovarium sphaericum, glabrum, stylo longiore quam ovarium. Fructus globosi, 11,2 mm diametro, pedunculis $11 \mathrm{~mm}$ longis, incrassatis; tepala ac stamina in fructu persistencia, pubescentia.

Árbol, 5-15 m alt.; ramas con sección transversal terete; yemas apicales cortas, glabras. Hojas con pecíolos de 1,5-4,2 × 0,13-0,34 cm, acanalados, glabros; láminas foliares elípticas, $18,7 \times 7,3 \mathrm{~cm}$, con largo:ancho igual a 2:1, glabras, ápice obtuso, raras veces agudo, redondeado o acuminado, base obtusa o aguda, margen ligeramente revoluto en toda la longitud de la lámina; nervio medio de igual grosor, hundido en la haz, glabro; venación broquidódroma o eucamptódroma, 6-10 pares de venas secundarias, divergentes en ángulo agudo hasta obtuso, rectas, a menudo ramificadas antes de alcanzar el margen, anastomosadas, uniéndose en ángulo agudo o recto a la vena secundaria supradyacente, con patrón percurrente, recto; venación marginal 


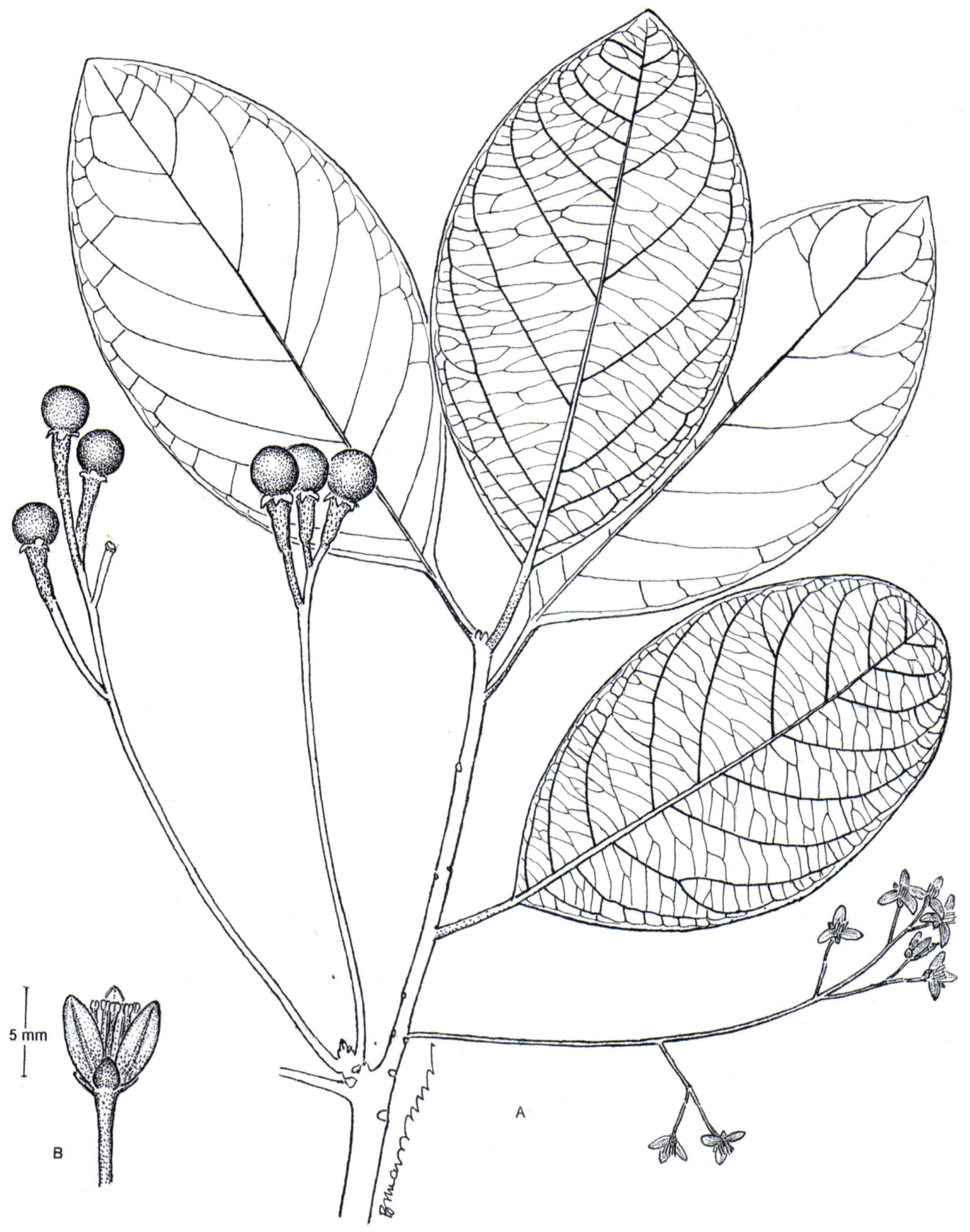

$5 \mathrm{~cm}$

Figura 12. P. lemensis. A. Hábito mostrando ramas con flores y frutos. B. Detalle de la flor.

Figure 12. P. lemensis. A. Habit showing twigs with flowers and fruits. B. Flower detail. 
formando lazos cerrados, areolas perfectamente desarrolladas, de forma angular o redondeada, sin venillas. Inflorescencias en racimos o panículas subterminales, hasta $21 \mathrm{~cm}$ long., más largas o tanto como las hojas adyacentes. Flores 6,0-6,2 × 7,0 mm, pedicelos 3,7-7,8 $\mathrm{mm}$ long. Tépalos conspicuamente desiguales entre sí, los tres externos tan largos como $1 / 3$ hasta $1 / 4$ de los internos, erectos, los externos con tricomas lisos, adpresos, con cobertura medianamente densa en la cara abaxial, mientras que los internos pubescentes en ambas caras. Estambres fértiles 9; anteras del V1 y V2 oblongas o trapezoidales, $0,8-1,0 \times 0,7-0,8 \mathrm{~mm}, 4$ lóculos, con dehiscencia introrsa, glabras, filamentos hasta 2,0-3,2 mm long., dos o tres veces la longitud de las anteras, pubescentes; anteras del V3 oblongas, 0,7-0,8 ×0,4 mm, 4 lóculos, con dehiscencia latrorsa, glabras, filamentos hasta 2,0-3,0 mm long., dos o tres veces más largos que las anteras, pubescentes, acompañados de un par de glándulas redondeadas, sésiles, adnadas a 1/4 de la longitud del filamento; estaminodios 3 , sagitados, hasta $2,0 \mathrm{~mm}$ long., pubescentes; ovario esférico, 1,0 × 1,0-1,25 mm diám., glabro, estilo 1,8-3,2 mm long., más largo que el ovario. Frutos globosos, 6,0-11,2 mm diám., pedúnculos 6,0-11,0 mm long., gradualmente engrosados hacia el receptáculo, de textura lisa o rugosa; tépalos y estambres persistentes, pubescentes.

Este taxón es una especie nueva recientemente identificada para Venezuela, en los bosques de la Sierra de Lema, sector La Escalera, y los tepuyes orientales cercanos a la Gran Sabana, en el sureste del Estado Bolívar.

Sus hojas son coriáceas, ligeramente rígidas, elípticas a anchamente elípticas, completamente glabras. Las flores tienen tépalos externos mucho más cortos que los internos, nueve estambres en tres verticilos estaminales y un cuarto verticilo estaminal estéril formado por estaminodios con ápices sagitados a cordados. El ovario es glabro, por lo que esta especie queda asignada a la sección Eriodaphne del subgénero Eriodaphne. Los frutos son globosos, con pedúnculos engrosados desde la base hacia el receptáculo, de color rojo coral en estado natural. Las hojas frescas tienen una apariencia glauca en el envés similar a P. caerulea, por lo que Kopp (1966) consideró que los ejemplares colectados por Steyermark y Nilsson pertenecían a esta última. Sin embargo, las hojas de $P$. caerulea son cartáceas, delgadas, frágiles y generalmente ovadas, raras veces elípticas; durante la fructificación los pedúnculos no se engrosan y los tépalos son parcialmente caducos. Se distingue de $P$. croizatii por la completa ausencia de tricomas en las hojas y porque los estambres de V3 nunca son más largos que los de V2. Podría considerarse afín a P. venosa, especie del sur de Brasil, pero se diferencia de ésta por la textura coriácea y rigidez de las hojas, la longitud de las inflorescencias y el engrosamiento de los pedúnculos durante la fructificación.

Parátipos: VENEZUELA. Bolívar: Cerro Marutani, Distrito Heres, $2 \mathrm{~km}$ NNW of camp along tributary of Río Carla, afluente de las cabeceras del Río Paragua, 11-14-I-1981, J. Steyermark, B. Maguire, C. Brewer-Carías \& V. Carreño E. 124078 (VEN); Cerro Uananapán, south of Uei-tepui, $2 \mathrm{~km}$ from campamento 132 between Luepa and Cerro Venamo, 25-IV-1960, J.A. Steyermark \& S. Nilsson 757 (VEN). Municipio Gran Sabana, Sierra de Lema, La Escalera, 12-13-VI-2006, E. Sanoja et al. 7895 (VEN, GUYN); Municipio Gran Sabana, Sierra de Lema, La Escalera, alrededores de la PN6, Km 751, 24-VI-2006, E. Sanoja et al. 8015 (VEN, GUYN); Parque Nacional Canaima, Río Cucurital, camino desde el campamento base a la quebrada del Río Purumay, 4-II-2000, R. Duno \& R. Riina 1376 (VEN, GUYN).

16. Persea maguirei L.E. Kopp, Mem. New York Bot. Gard. 10(5): 73. 1964. Tipo: VENEZUELA. Amazonas: Cerro Duida, Rio Cunucunuma, along north escarpment above Culebra, $1.400 \mathrm{msnm}$, 20-XI-1950, B. Maguire et al. 29599 (Holótipo NY!, Isótipo VEN!).

Figura 11D

Arbusto, 2 m alt.; ramas con sección transversal terete, con tricomas amarillentos, lisos, adpresos, con cobertura medianamente densa; yemas apicales cortas, con indumento igual que las ramas. Hojas distribuidas a lo largo de las ramas, pecíolos $1,0 \times 0,11 \mathrm{~cm}$, acanalados, pubescentes; láminas foliares elípticas, 5,5-6,2 × 1,5-2,2 cm, con largo:ancho igual a 2:1-3:1, ápice obtuso, redondeado, base aguda, decurrente, margen ligeramente revoluto, en toda la longitud de la lámina, cubiertas con tricomas amarillentos, lisos, adpresos, con cobertura densa, con el nervio medio de igual grosor en toda su extensión, hundido en la haz, glabro; venación eucamptódroma, 8 pares de venas secundarias, divergentes en ángulo obtuso, curvas, no anastomosadas. Inflorescencias paucifloras, en racimos subterminales o axilares, hasta $4,5 \mathrm{~cm}$ long., alcanzando 3/4 de la longitud de las hojas adyacentes. Flores 5,0 $\mathrm{mm}$ long., pedicelos 3,0 $\mathrm{mm}$ long. Tépalos conspicuamente desiguales entre sí, los 
tres externos tan largos como $1 / 3$ de los internos, patentes, los externos con tricomas amarillentos, lisos, adpresos, con cobertura densa en la cara abaxial, mientras que los internos presentan tricomas en ambas caras. Estambres fértiles 9; anteras del V1 y V2 trapezoidales, $1,0 \times 0,7 \mathrm{~mm}, 4$ lóculos, con dehiscencia introrsa, pubescentes, filamentos hasta 1,3 mm long., ligeramente más largos que las anteras, densamente pubescentes; anteras del V3 rectangulares, $0,5 \times 0,3 \mathrm{~mm}, 2$ lóculos, con dehiscencia latrorsa, glabras, filamentos hasta 2,0 mm long., densamente pubescentes, acompañados de un par de glándulas cordadas, sésiles, adnadas en la parte basal del filamento; estaminodios 3, sagitados, hasta 1,8 mm long., pubescentes; ovario elipsoidal, $1,0 \times 0,9 \mathrm{~mm}$, cubierto por tricomas amarillentos, lisos, adpresos, con cobertura densa; estilo 2,2 mm long., más largo que el ovario, pubescente. Fruto desconocido.

Persea maguirei se considera endémica de Venezuela y sólo se conoce del tipo. Esta especie se reconoce fácilmente por tener hojas elípticas de margen ligeramente revoluto, menores de $7,0 \mathrm{~cm}$ de longitud, glabras en la haz y densamente pubescentes en el envés. Las inflorescencias tanto o ligeramente más cortas que las hojas, paucifloras, sosteniendo flores de 5,0 a 6,0 $\mathrm{mm}$ de longitud, tan pubescentes como las hojas. El indumento está conformado por tricomas lisos, adpresos, pardo-ferruginosos, que ocultan la superficie del envés de las hojas, tépalos e inflorescencias. El tamaño de las hojas y las inflorescencias permiten diferenciarla frente a P. grandiflora y $P$. perseiphylla.

17. Persea meridensis L.E. Kopp, Mem. New York

Bot. Gard. 14(1): 81. 1966. Tipo: VENEZUELA.

TrujILlo: El Paramito near Escuque, VIII-1944, T. Lasser 1206 (Holótipo US!, Isótipo VEN!). Figuras 1B, 3G, 13A.

Árbol, 8-15 m alt.; ramas con sección transversal terete, cubiertas por tricomas amarillentos o parduzcos, lisos u ondulados, ascendentes, raras veces adpresos, con cobertura laxa a medianamente densa; yemas apicales cortas, con indumento igual que las ramas. Hojas agrupadas en las puntas o distribuidas a lo largo de las ramas, pecíolos 2,25-3,50 × 0,17-0,30 cm, acanalados, glabros o pubescentes; láminas foliares elípticas, 13,0-19,3 × 3,6-6,3 cm, con largo:ancho igual a $2: 1$ a $3: 1$, tricomas amarillentos o parduzcos, lisos u ondulados, ascendentes, raras veces adpresos, con cobertura medianamente densa a densa, ápice agudo, acuminado, base aguda u obtusa, decurrente o desigual, ligeramente revoluto hasta la mitad o en toda la longitud de la lámina; nervio medio hundido en la haz, glabro; venación eucamptódroma, 7-10 pares de venas secundarias, divergentes en ángulo recto hasta obtuso, a veces ramificadas antes de alcanzar el margen, a menudo anastomosadas, cerrándose por $\operatorname{arcos}$ secundarios formados por venas de $3^{\circ} \mathrm{y} 4^{\circ}$ orden, con patrón reticulado ortogonal a percurrente recto; venación marginal formando lazos cerrados, cuando visibles, las areolas perfectamente desarrolladas, de forma angular y sin venillas. Inflorescencias en racimos o panículas subterminales a axilares, hasta $25,0 \mathrm{~cm}$ long., más largas que las hojas adyacentes o hasta $3 / 4$ de la longitud de las hojas adyacentes. Flores 4,0-7,0 mm long., pedicelos 2,0-8,0 mm long. Tépalos conspicuamente desiguales entre sí, los tres externos tan largos como $1 / 2$ a $1 / 3$ de los internos, los externos con tricomas amarillentos o parduzcos, lisos u ondulados, ascendentes, raras veces adpresos, con cobertura densa en la cara abaxial, mientras que los internos son pubescentes en ambas caras. Estambres fértiles 6; anteras del V1 y V2 ovadas, 1,0-1,2 × 0,5-0,8 mm, 4 lóculos, con dehiscencia introrsa, glabras o pubescentes en la base de las anteras, filamentos hasta 1,7 mm long., hasta dos veces la longitud de las anteras, pubescentes; anteras del V3 reducidas, filamentos hasta 2,5 $\mathrm{mm}$ long., pubescentes, acompañados de un par de glándulas redondeadas, brevemente estipitadas, adnadas a 1/4 de la longitud del filamento; estaminodios 3 , sagitados, hasta 2,0 mm long., pubescentes; ovario esférico o deprimido-globoso, $0,8-1,0 \times 1,0-1,2 \mathrm{~mm}$, glabro, estilo 1,3-2,0 mm long., igual o más largo que el ovario. Frutos deprimido-globosos, 11,0-12,0 mm diám., pedúnculos 7,0 mm long., gradualmente engrosados hacia el receptáculo, de textura rugosa; tépalos y estambres persistentes, pubescentes.

Considerando las observaciones de van der Werff (2008), esta especie ha sido colectada en bosques nublados de los estados Mérida, Trujillo y Portuguesa, entre 1.600 y $2.200 \mathrm{msnm}$. Las colecciones cercanas al topotipo (Lasser 1206 y Ferrer \& Romero 425) tienen hojas alargadas, de casi 25,0 cm de longitud, anchamente elípticas hasta oblongas, coriáceas y onduladas, con tricomas amarillentos en la cara abaxial, ramas y yemas. Las inflorescencias son subterminales, generalmente sésiles, tanto o más cortas 


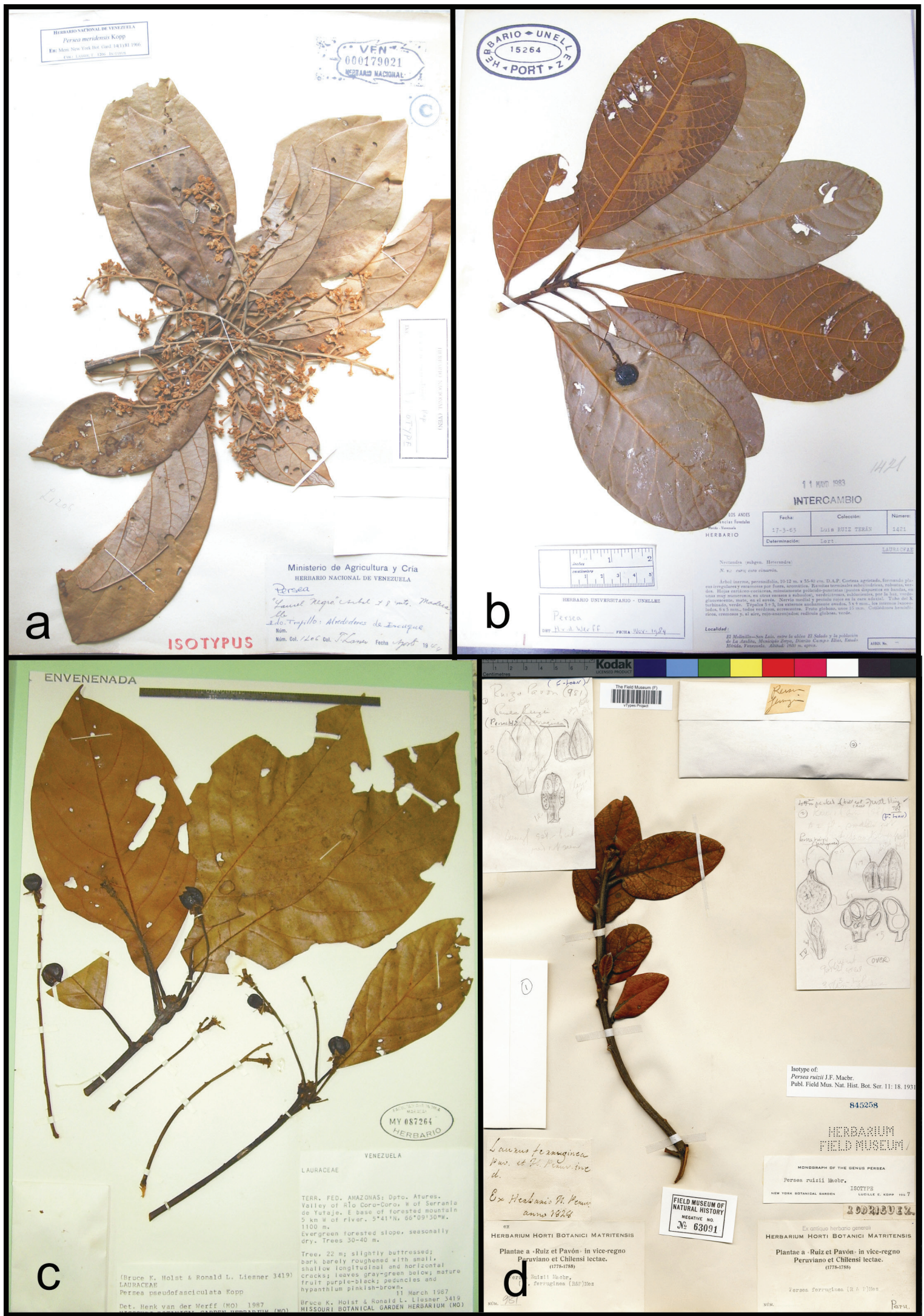

Figura 13. Imágenes de las colecciones examinadas. A. Persea meridensis. B. P. povedae. C. P. pseudofasciculata. D. P. ruizii.

Figure 13. Images of examined vouchers. A. Persea meridensis. B. P. povedae. C. P. pseudofasciculata. D. P. ruizii. 
que las hojas, cubiertas de tricomas amarillentos. En la fructificación, los pedúnculos se engrosan y tornan rojizos, mientras los tépalos y estambres persisten.

Por otro lado, las colecciones realizadas en los estados Portuguesa y Trujillo, en áreas del Parque Nacional Guaramacal, tienen hojas más cortas y estrechas, elípticas a oblanceoladas, con pubescencia de cobertura variable e inflorescencias axilares, mucho más largas que las hojas. Por lo tanto, existen diferencias sustanciales entre los taxones determinados por van der Werff y el holótipo, lo que podría indicar que se trata de especies diferentes que forman un complejo variable denominado P. meridensis s.l. Este complejo constituye un punto débil en la revisión debido al número reducido de especímenes colectados en estado reproductivo. Así mismo, los caracteres reportados por la literatura especializada para diferenciar entre $P$. hexanthera y las colecciones de $P$. meridensis de Guaramacal son vagos e inconsistentes por lo que se requiere obtener más información para esclarecer la circunscripción de las dos especies.

Materiales examinados: VENEZUELA. MÉRIdA: Carretera San Francisco-Guaraque, Distrito Rivas Dávila, 10-V-1967, L. Marcano Berti \& López Palacios 1730 (VEN, MER, US). Portuguesa: Distrito Sucre, La Divisoria de la Concepción, 24-X-1985, H. van der Werff et al. 7621 (K, F). TRujILLo: Carretera Escuque-Mesa de San Pedro, 1,5 km antes de Mesa de San Pedro, después del Tanque Paramito, 17-III-2008, H. Ferrer \& S. Romero 425.

18. Persea mutisii Kunth, Nov. Gen. Sp. 2: 158. 1817.

Tipo: COLOMBIA. s.l., s.d. A. von Humboldt s.n. (Sintipo B!).

=Persea pachytepala Lasser, Bol. Soc. Venez. Ci. Nat. 9: 178. 1944. Tipo: VENEZUELA. MÉRIDA: La Cañada de Los Cedros, arriba de Bailadores, 2.300 msnm, 20-IX-1942, F. Tamayo 2454 (Holótipo VEN!). Figuras 1A, 2J.

Arbusto, raras veces árbol, 1-8 m alt.; ramas con sección transversal angular, glabro, raras veces cubiertas por tricomas amarillentos a parduzcos, lisos u ondulados, adpresos, raras veces ascendentes, con cobertura laxa; yemas apicales cortas, glabras, raras veces con indumento igual que las ramas. Hojas distribuidas a lo largo de las ramas, pecíolos 0,70-2,5 $\times 0,25-0,58 \mathrm{~cm}$, aplanados o anchamente acanalados, glabros, raras veces pubescentes; láminas foliares a menudo elípticas, pocas veces ovadas $\mathrm{u}$ obovadas, 5,2-16,0 × 3,1-10,8 cm, con largo:ancho igual a 1:1 a 2:1, muy raras veces más de 4:1, glabras, raras veces con tricomas amarillentos a parduzcos, lisos $\mathrm{u}$ ondulados, adpresos o ascendentes, con cobertura laxa en la cara abaxial, ápice obtuso, redondeado o acuminado, base obtusa, ligeramente cordada o cuneada, margen entero; nervio medio más ancho en la mitad basal, glabro; venación broquidódroma o eucamptódroma, 7-11 pares de venas secundarias, divergentes en ángulo obtuso, menos frecuente en ángulo recto o agudo, curvas, ramificadas antes de alcanzar el margen, anastomosadas, cerrándose por arcos secundarios formados por venas de $3^{\circ}$ y $4^{\circ}$ orden, con patrón reticulado ortogonal; venación marginal formando lazos cerrados o fimbriada, areolas perfectamente desarrolladas, de forma angular, con venillas rectilíneas o con ramificación simple dentro de la areola. Inflorescencias de apariencia corimbiforme, subterminales, hasta $6,6 \mathrm{~cm}$ long., ligeramente más largas que las hojas adyacentes o alcanzando $3 / 4$ de la longitud de las hojas adyacentes. Flores 3,0-7,0 × 4,0 mm, pedicelos 1,5-2,0 $\mathrm{mm}$ long., engrosados hacia el receptáculo. Tépalos conspicuamente desiguales entre sí, los tres externos tan largos como la mitad de los internos, erectos, los externos con tricomas amarillentos a parduzcos, lisos u ondulados, adpresos, raras veces ascendentes, con cobertura medianamente densa en la cara abaxial, mientras que los internos presentan tricomas en ambas caras. Estambres fértiles 9; anteras del V1 y V2 ovadas, 1,2-1,4 × 0,6-0,8 mm, 4 lóculos, con dehiscencia introrsa, glabras, filamentos hasta $2,0 \mathrm{~mm}$ long., de igual longitud hasta dos veces la longitud de las anteras, pubescentes; anteras del V3 triangulares o trapezoidales, 1,0-1,4 × 0,4-0,6 mm, 4 lóculos, con dehiscencia extrorsa-latrorsa, glabras, filamentos hasta 2,5 mm long., ligeramente más largos o dos veces más largos que las anteras, pubescentes, acompañados de un par de glándulas redondeadas, sésiles, adnadas a 1/4 de la longitud del filamento; estaminodios 3, sagitados, hasta $0,8-1,2 \mathrm{~mm}$ long., pubescentes; ovario esférico o elipsoidal, 1,2-1,5 × 0,8-1,3 mm, glabro, estilo 2,0-2,5 mm long., más largo que el ovario. Frutos globosos, 10,0-13,0 mm diám., pedúnculos 5,0-5,5 mm long., gradualmente engrosados hacia el receptáculo, de textura lisa; tépalos y estambres persistentes, pubescentes.

Presenta una distribución estrictamente relacionada con las regiones altas de Colombia, 
Ecuador, Perú y Venezuela. En Venezuela se ha colectado generalmente matorrales subparameros y arbustales bajos, por encima de $2.000 \mathrm{msnm}$ en la Cordillera Andina y de los $1.500 \mathrm{msnm}$ en la Cordillera de la Costa, siendo conjuntamente con $P$. ferruginea, una de las especies del género con mayor altitud registrada en Venezuela $(3.300 \mathrm{msnm})$.

Puede ser claramente reconocida por las hojas obovadas hasta anchamente elípticas, coriáceas, rígidas, con pecíolos anchamente dilatados y sus inflorescencias subterminales, corimbiformes. Las hojas pueden ser completamente glabras hasta glabrescentes en la cara abaxial y los tépalos son persistentes durante la fructificación, endurecidos y lignificados, sosteniendo frutos globosos de $1,0 \mathrm{~cm}$ de diámetro. Es de hacer notar, que este taxón está emparentado con un grupo de especies de la sección Mutisaea que presenta morfología y rango de distribución similares. Con ello, los caracteres diagnósticos señalados por Kopp (1966) han resultado variables entre las nuevas colecciones realizadas y se hace necesario revisar colecciones de todos los taxones del grupo para determinar la circunscripción taxonómica de los mismos.

Materiales examinados: VENEZUELA. AnZoÁtEGUI: Distrito Libertad: ridges and tops of Montañas Negras, along the Sucre and Anzoátegui border, 20 airline km NE of Bergantín, NE of Buenos Aires, Serranía de Turimiquire, 28-XI-1981, G. Davidse \& A. González 19628 (VEN, IRBR). Apure: Páramo de Tamá, 26-III-1997, B. Manara s.n. (VEN318174). BARINAS: Distrito Pedraza, trail from Carrizal, ca. $8^{\circ} 39^{\prime} \mathrm{N}$, $70^{\circ} 46^{\prime} \mathrm{W}$ to Micarache, ca. $8^{\circ} 41^{\prime} \mathrm{N}, 70^{\circ} 54^{\prime} \mathrm{W}$, along the Quebrada Micarache, Parque Nacional Sierra Nevada, 28-VI-1988, L.J. Dorr et al. 5750 (PORT). Mérida: Páramo del Cupis, zona de Pozo Negro, Municipio San José y Mucutuy, Distrito Campo Elías, 23-III-1967, L. Ruiz Terán et al. 3905 (VEN, MY, MERF). Monagas: Cerro Negro, above La Sabana de las Piedras, northwest of Caripe, 15-IV-1945, J.A. Steyermark 62092 (VEN, F, HUH). SuCRE: Cerro Turimiquire: north-facing steep sandstone slopes, from beginning to summit of cerro, 6-V-1945, J. Steyermark 62598 (VEN, F). TÁCHIRA: faldas inmediatamente debajo del Páramo de Tamá, cerca de la frontera Colombo-Venezolana, 20-23-V-1967, J. Steyermark et al. 98770 (VEN). TrujILlo: montañas de Misisí, carretera vieja Trujillo-Boconó, $10 \mathrm{~km}$ suroeste de la carretera principal Boconó-Flor de Patria, 25-IX-1981, J. Steyermark \& B. Manara 125353 (VEN, MERF).
19. Persea perseiphylla (C.K. Allen) van der Werff, Ann. Missouri Bot. Gard. 76(3): 961. 1989 $\equiv$ Ocotea perseiphylla C.K.Allen, Mem. New York Bot. Gard. 10(5): 109. 1964. Tipo: COLOMBIA. VAupÉs: Rio Guainia basin, Rio Naquieni, vicinity of Cerro Monachi. IV-1948, R.E. Schultes \& F. López 10103 (Holótipo US!).

Árbol o arbusto, 1,5-6 m alt., ramas con sección transversal terete, con tricomas lisos, generalmente parduzcos, raramente blanquecinos, adpresos o ascendentes, con cobertura densa; yemas apicales cortas, con indumento igual que las ramas. Hojas distribuidas a lo largo de las ramas; pecíolos 1,1-2,2 × 0,20-0,28 cm, acanalados o estriados longitudinalmente, pubescentes; láminas foliares elípticas, 8,9-15,0 × 2,9-6,2 cm, con largo:ancho igual a 2:1 a 3:1, ápice obtuso a agudo, base obtusa, raras veces aguda, cuneada, margen ligeramente revoluto en la base de la lámina, con tricomas lisos, generalmente parduzcos, raramente blanquecinos, adpresos o ascendentes, de cobertura densa; nervio medio pubescente; venación eucamptódroma, 6-7 pares de venas secundarias, divergentes en ángulo obtuso, curvas, a menudo no anastomosadas, con patrón percurrente recto o convexo. Inflorescencias en racimos o panículas subterminales o axilares, hasta 23,5 cm long., alcanzando 3/4 hasta dos veces más largas que las hojas adyacentes. Flores 5,0 mm long.; pedicelos 2,5 $\mathrm{mm}$ long. Tépalos conspicuamente desiguales entre sí, los tres externos tan largos como $1 / 2$ de los internos, patentes, los externos cubiertos por tricomas lisos, generalmente parduzcos, raramente blanquecinos, adpresos o ascendentes, con cobertura densa en la cara abaxial, mientras que los internos presentan tricomas pubescentes en ambas caras. Estambres fértiles 9; anteras del V1 y V2 ovadas, 1-1,2 × 1,7-2 mm, 4 lóculos, con dehiscencia introrsa, pubescentes; filamentos hasta $1,0 \mathrm{~mm}$ long., de igual longitud que las anteras, pubescentes; anteras del V3 rectangulares, 1,0 × 0,5 mm, 4 lóculos, con dehiscencia extrorsa-latrorsa, pubescentes, filamentos hasta 0,6-2,2 mm long., pubescentes, acompañados de un par de glándulas redondeadas, sésiles, adnadas en la parte basal del filamento; estaminodios 3, sagitados, hasta 1,2 mm long., pubescentes; ovario ovado o deprimido-globoso, 0,8-1,0 $\times 0,8-1,6 \mathrm{~mm}$, pubescente; estilo $0,7-1,3 \mathrm{~mm}$ long., pubescente, más largo que el ovario. Frutos globosos de 6,8-8,5 mm diám., pedúnculos 4,5 mm long., no engrosados, de textura lisa; tépalos y estambres persistentes, pubescentes. 
Ha sido colectada al sur del Estado Amazonas, en los alrededores de La Neblina y el Cerro Aracamuni, entre 550 y $1.700 \mathrm{msnm}$. También ha sido colectada en la región guayanesa de Colombia (Vaupés y Guainia).

Las hojas son elípticas, con tricomas lisos, adpresos, de color pardo cobrizo que cubren toda la superficie abaxial. Las inflorescencias alcanzan longitudes iguales o más cortas que las hojas. Se diferencia de $P$. maguirei por la longitud de las hojas y de $P$. grandiflora por la forma de las láminas foliares, el color del indumento en el envés y las inflorescencias mucho más cortas. Debido a la presencia de ovario pubescente y nueve estambres fértiles, esta especie se incluye en la sección Aurataea del subgénero Eriodaphne, al igual que las dos especies antes mencionadas.

Materiales examinados: VENEZUELA. AmAzonAs: Neblina Camp 10: $12.5 \mathrm{~km}$ NNW of Pico Phelps (=Pico Neblina), $16.25 \mathrm{~km} \mathrm{NE}$ of Base Camp, 12-II-1985, B.M. Boom \& A.L. Weitzman 5743 (US); Departamento Río Negro, Cerro Aracamuni, Campamento La Proa, 30-X-1987, G. Carnevali et al. 2565 (VEN, PORT); Departamento Río Negro, Cerro Aracamuni, summit. Popa Camp, 18-X-1987, R. Liesner \& F. Delascio 22099 (VEN); Departamento Río Negro, Cerro Aracamuni, summit, Popa Camp, savanna with small to large patches of forest and stream, 19-X-1987, R. Liesner \& F. Delascio 22169 (VEN); Departamento Río Negro, vertiente sur de la Sierra de Unturán en las cabeceras del río Mavaca, 26-II-1981, F. Guánchez 809 (TFAV).

20. Persea povedae W.C. Burger, Fieldiana: Bot., n.s. 23: 105, 1990. Tipo: COSTA RICA. Alajuela: La Paz de San Ramón, 30-X-1973, Poveda 740 (Holótipo CR!).

Figuras 2A, 13B.

Árbol, hasta $30 \mathrm{~m}$ alt., $50 \mathrm{~cm}$ DAP; ramas con sección transversal angular; yemas apicales cortas, glabras. Hojas distribuidas a lo largo de las ramas, pecíolos 3,0-4,5 × 0,16-0,20 cm, acanalados, glabros; láminas foliares obovadas, 10,4-19,6 × 4,4-8,8 cm, con largo:ancho igual a 2:1 a 3:1, ápice obtuso, redondeado, a veces acuminado, base aguda, cuneada o desigual, margen entero o ligeramente revoluto en toda la longitud de la lámina, glabras; nervio medio glabro; venación broquidódroma, 10-12 pares de venas secundarias, divergentes en ángulo obtuso, curvas, ramificadas antes de alcanzar el margen, anastomosadas, uniéndose en ángulo recto a la vena secundaria supradyacente o cerrándose por arcos secundarios formados por venas de $3^{\circ}$ y $4^{\circ}$ orden, con patrón reticulado ortogonal; venación marginal formando lazos cerrados, areolas perfectamente desarrolladas, de forma angular, con venillas rectilíneas dentro de la areola. Inflorescencias en racimos subterminales o axilares, hasta 15,3 cm long., alcanzando $1 / 3$ o tan largas como las hojas adyacentes. Flores 5,0 mm long.; pedicelos 3,0 $\mathrm{mm}$ long. Tépalos conspicuamente desiguales entre sí, los tres externos tan largos como un cuarto o menos que los internos, erectos, los externos cubiertos por tricomas lisos, adpresos, rara vez erectos, con cobertura densa en la cara abaxial o sólo el margen, mientras que los internos presentan tricomas en ambas caras de los tépalos internos. Estambres fértiles 9; anteras del V1 y V2 oblongas, 1,0-1,2 × 0,6 mm, 4 lóculos, con dehiscencia introrsa, glabras o pubescentes en la cara abaxial, filamentos hasta 1,8-2,2 $\mathrm{mm}$ long., hasta dos veces la longitud de las anteras, pubescentes; anteras del V3 rectangulares, $1,0 \times 0,4 \mathrm{~mm}, 4$ lóculos, con dehiscencia latrorsa, glabras o cubiertas pubescentes en la cara abaxial, filamentos hasta 3,0 mm long., dos o tres veces más largos que las anteras, pubescentes, acompañados de un par de glándulas redondeadas, subsésiles, adnadas a $1 / 4$ o a $1 / 3$ de la longitud del filamento; estaminodios 3, sagitados, hasta 2,0 mm long., pubescentes; ovario esférico, 1,0 × 1,0 mm, glabro, estilo $3 \mathrm{~mm}$ long., más largo que el ovario. Frutos globosos a deprimido-globosos, 12,3-15,0 mm diám., con pedúnculos 7,0-12,0 mm long., gradualmente engrosados hacia el receptáculo, de textura lenticelada; tépalos acrescentes y persistentes en el fruto, pubescentes, estambres también persistentes.

El rango de distribución de Persea povedae alcanza Colombia, Panamá, Costa Rica y Ecuador. Esta especie constituye un nuevo reporte para la flora venezolana y ha sido colectada en los estados Aragua y Mérida. La altitud de ocurrencia varía entre 800 y $1.680 \mathrm{msnm}$.

Se reconoce rápidamente por las hojas largas, entre 10,0 y $30,0 \mathrm{~cm}$ de longitud, siempre obovadas, con numerosos pares de venas secundarias y pecíolos de más de 2,0 $\mathrm{cm}$ de longitud. Las inflorescencias suelen ser tan largas o más cortas que las hojas, los frutos llegan a medir más de $1,0 \mathrm{~cm}$ de diámetro y están sostenidos por pedúnculos engrosados, con lenticelas conspicuas; los tépalos son persistentes y reflejos.

Materiales examinados: VENEZUELA. Aragua: Distrito Girardot. Parque Nacional Henry Pittier, cerca 
del mar, 6-I-68, R.F. Smith V3260(UCOB); R.F. Smith V3261 (VEN). Mérida: Los Molinillos, Municipio Zerpa, Distrito Andrés Bello, 24-I-1980, E. Ara 11 (MER); El Molinillo-San Luis, entre la aldea El Salado y la población de La Azulita, Municipio Zerpa, Distrito Campo Elías, 17-III-1963, L. Ruiz-Terán 1421 (PORT, HERZU).

21. Persea pseudofasciculata L.E. Kopp, Mem. New York Bot. Gard. 14(1): 85. 1966. Tipo:BOLIVIA. LA PAZ: Larecaja, Copacabana, about $10 \mathrm{~km} \mathrm{~S}$ of Mapiri, X-XI-1939, B.A. Krukoff 11283 (Holótipo NY!). Figuras $2 \mathrm{~F}, 13 \mathrm{C}$.

Árbol, de $22 \mathrm{~m}$ alt., 17,7 cm DAP; ramas con sección transversal terete o angular, glabras o raras veces con tricomas amarillentos, lisos, adpresos, con cobertura muy laxa; yemas apicales cortas, glabras. Hojas distribuidas a lo largo de las ramas; pecíolos 2,7-4,0 × 0,17-0,26 cm, acanalados, glabros, raras veces pubescentes; láminas foliares elípticas, 11,0-22,5 × 5,5-9,7 cm, con largo:ancho igual a 2:1 a $3: 1$, pubescentes, ápice agudo, acuminado, base aguda u obtusa, desigual, margen entero, ligeramente revoluto en la base o en toda la longitud de la lámina, glabras o con tricomas amarillentos, lisos, adpresos, con cobertura muy laxa en la cara abaxial; nervio medio hundido en la haz, glabro; venación eucamptódroma, 6-9 pares de venas secundarias, divergentes en ángulo agudo hasta obtuso, curvas, pocas veces ramificadas antes de alcanzar el margen, cuando anastomosadas se cierran por arcos secundarios formados por venas de $3^{\circ}$ y $4^{\circ}$ orden, con patrón reticulado ortogonal o percurrente recto; venación marginal formando lazos cerrados, areolas perfectamente desarrolladas, de forma angular. Inflorescencias en racimos subterminales o axilares, hasta $16,0 \mathrm{~cm}$ long., alcanzando $1 / 4$ o menos, raras veces $1 / 2$ de la longitud de las hojas adyacentes. Flores 2,20-2,85 mm long.; pedicelos 1,0-3,0 mm long., engrosados hacia el receptáculo. Tépalos conspicuamente desiguales entre sí, los tres externos tan largos como $1 / 3$ o menos de $1 / 4$ que los internos, cubiertos por tricomas amarillentos, lisos, adpresos, con cobertura densa en la cara abaxial; mientras que los internos presentan tricomas en ambas caras. Estambres fértiles 6, anteras del V1 y V2 oblongas, 4 lóculos, con dehiscencia introrsa, glabras, filamentos hasta 2,5 mm long., más largos que las anteras, pubescentes; anteras de V3 reducidas, filamentos hasta $4,5 \mathrm{~mm}$ long., pubescentes; estaminodios 3, sagitados; ovario globoso u obovoide,
0,8-1,3 mm long., glabro, estilo más largo que el ovario. Frutos obovoides o globosos, 10,8-15,0 mm diám., pedúnculos 5,0 mm long., a menudo gradualmente engrosados hacia el receptáculo, de textura lisa o lenticelada; tépalos y estambres persistentes, pubescentes.

Especie de amplia distribución en el continente americano, desde Costa Rica hasta Bolivia, entre 140 y $1.110 \mathrm{msnm}$, considerándose principalmente una especie de origen guayanés. Su presencia en Venezuela está restringida al sur del Orinoco, en el Estado Amazonas, generalmente en bosques de tierra firme.

Presenta hojas completamente glabras hasta glabrescentes, anchamente ovadas a elípticas, con nerviación broquidódroma perfecta, formada por 5 a 6 venas secundarias recurvas que se unen directamente a la supradyacente de forma conspicua. Los pecíolos oscilan entre 2,5 y $4,0 \mathrm{~cm}$ de longitud y tienen un color pardo oscuro característico. Las inflorescencias son axilares, raras veces subterminales, sésiles y muy cortas ya que alcanzan hasta $1 / 4$ de la hoja. Las flores sólo tienen seis estambres fértiles que representan los verticilos exteriores. En la fructificación, los tépalos persisten y los pedúnculos se engrosan hacia el receptáculo, llegando a distinguirse lenticelas conspícuas. La especie más afín es $P$. fluviatilis debido a que ambas comparten extensión de ocurrencia en las tierras bajas de Amazonas y tienen características morfológica que las hacen muy similares. Se diferencian porque $P$. fluviatilis tiene tallos huecos, hojas elípticas hasta lanceoladas, alargadas e inflorescencias casi tan largas como las hojas. Por otra parte, P. pseudofasciculata prefiere los bosques de tierra firme, no inundables.

Materiales examinados: VENEZUELA. AmAzonAs: Cerro Neblina, valley near camp \#5 at $\mathrm{N}$ base of Pico Cárdenas, 13-IV-1984, A. Gentry \& B. Stein 46632 (VEN); Cerro Neblina base camp on Río Mawarinuma, 19-IV-1984, A. Gentry \& B. Stein 46754 (VEN, US); Departamento Atures, valley of Río CoroCoro, W of Serranía de Yutaje, E base of forested mountain $5 \mathrm{~km} \mathrm{~W}$ of river, 11-III-1987, B.K. Holst \& R.L. Liesner 3419 (VEN, MY, PORT, F, K); Neblina Base Camp, Río Mawarinuma, 28-I-1985, B.M. Boom \& A.L. Weitzman 5405 (VEN).

22. Persea rigens C.K. Allen, J. Arnold Arbor. 26(3): 297. 1945. Tipo: COSTA RICA. Sin localidad, 1943 , E.L. Little 6058 (Lectótipo F!) 
22.1. Persea rigens var. oblaticarpa $\mathrm{H}$. Ferrer var. nov. Tipo: VENEZUELA. Monagas: Cerro Turimiquire: north facingslopes, betweenLaTrinidadandQuebrada El Boquerón, southwest of Cocollar, 1.700-1.840 msnm, 3-V-1945, J.A. Steyermark 62459 (Holótipo VEN!).

Figuras 2C, 14.

Persea rigens var. oblaticarpa notabilis: fructibus oblatis, breviter stipitatis, tepalis persistentibus, reflexis, infructificatione accrescetibus.

Árbol, hasta $30 \mathrm{~m}$ alt.; ramas con sección transversal terete, generalmente glabras, o raras vees cubiertas por tricomas blanquecinos, lisos, adpresos, con cobertura muy laxa; yemas apicales cortas, glabras. Hojas agrupadas en las puntas de las ramas; pecíolos de 1,1-2,8 × 0,2-0,4 cm, aplanados, glabros; láminas foliares elípticas u ovadas, 11,5-34,0 × 4,6-13,3 cm, con largo:ancho igual a 2:1 a 3:1, ápice agudo, raras veces obtuso, acuminado, base obtusa, raras veces aguda, cuneada, margen entero, glabras o con tricomas blanquecinos, lisos, adpresos, con cobertura muy laxa en la cara abaxial; nervio medio ligeramente más ancho en la mitad basal, cóncavo en la haz, glabro; venación broquidódroma, 8-11 pares de venas secundarias, divergentes en ángulo obtuso, raras veces recto, curvas, a menudo ramificadas antes de alcanzar el margen, anastomosadas, cerrándose por arcos secundarios formados por venas de $3^{\circ} \mathrm{y} 4^{\circ}$ orden o uniéndose en ángulo recto a la vena secundaria supradyacente, con patrón reticulado aleatorio; venación marginal fimbriada, areolas perfectamente desarrolladas, de forma redondeada, a menudo con venillas rectilíneas dentro de la areola. Inflorescencias en racimos subterminales, hasta $10,0 \mathrm{~cm}$ long., alcanzando $1 / 3$ o menos de la longitud de las hojas adyacentes. Flores 3,0 mm long., pedicelos 2,5 mm long. Tépalos iguales a subiguales entre sí, erectos, cubiertos por tricomas blanquecinos, lisos, adpresos, con cobertura densa en ambas caras de los dos verticilos. Estambres fértiles 9; anteras del V1 y V2 trapezoidales, 4 lóculos, con dehiscencia introrsa, glabras o pubescentes en la cara abaxial; ligeramente más largos que las anteras, pubescentes; anteras del V3 rectangulares, 4 lóculos, con dehiscencia extrorsa-latrorsa, glabras o pubescentes en la cara abaxial, ligeramente más largos que las anteras, pubescentes, acompañados de un par de glándulas redondeadas, estipitadas, adnadas en la parte basal del filamento; estaminodios 3, sagitados, glabros o pubescentes; ovario ovado o deprimido-globoso, glabro, estilo más largo que el ovario. Frutos oblados, 21,0-30,0 mm diám., pedúnculos 10,0-11,0 mm long., gradualmente engrosados hacia el receptáculo, de textura lenticelada; tépalos acrescentes y persistentes en el fruto, pubescentes; estambres también persistentes.

Las hojas son lanceoladas a elípticas, coriáceas, con envés glauco y se agrupan en los extremos de las ramas, quedando fuertemente congestionadas. Las inflorescencias subterminales suelen ser tan largas como las hojas y están cubiertas de tricomas blanquecinos, así como las flores, lo cual les da una apariencia cinerea. De manera muy particular, los frutos observados para este taxón son deprimido-globosos, con una base constricta; los tépalos son persistentes y reflejos y los pedúnculos son engrosados y lenticelados. De acuerdo con van der Werff (2002), la asignación de las colecciones examinadas por Kopp (1966) para este taxón son erróneas, llegando a considerar que los especímenes venezolanos forman una entidad distinta. Las colecciones recientemente realizadas en Panamá (Hammel 17503, CR), indican que los frutos de $P$. rigens son globosos, de forma claramente esférica, y no deprimido-globosos como se señala en la descripción original del taxón, por lo que van der Werff (2002) acota una asignación equivocada por parte de Allen (1945). Debido a la diferencia morfológica de los frutos y la disyunción en la distribución, se propone la creación de dos variedades, a saber $P$. rigens var. rigens y $P$. rigens var. oblaticarpa, siendo la primera un taxón presente en Costa Rica y Panamá, mientras que las colecciones venezolanas reportadas en esta investigación pertenecen a la variedad oblaticarpa.

Cabe destacar que se requiere obtener mayor número de colecciones en estado reproductivo para determinar con precisión la circunscripción taxonómica de este taxón.

Parátipos: VENEZUELA. AnzoÁtegui: along Río Zumbador and tributary, near base of Piedra Blanca, northeast of Bergantín, 1-2-III-1945, J. Steyermark 61307 (VEN, F). LARA: $7.9 \mathrm{~km}$ al sur de Agua Negra, 21-23 km al este de Cubiro, hacia Nuezal, Distrito Menez, 6-VII-1974, J. Steyermark et al. 110164 (VEN). MonaGas: Northeast of Guácharo, 11-IV-1945, J.A. Steyermark 61989 (VEN, F). Portuguesa: Municipio Sucre, límite con el estado Trujillo, sector El Mogote: Bosques húmedos de la vertiente norte del ramal de Guaramacal, límite del Parque Nacional Guaramacal, parcela de estudio fitosociológico $\mathrm{N}^{\mathrm{o}} 14$, 21-XII-1999, N. Cuello et al. 1770 (VEN, PORT). SuCRE: Cerro Turimiquire: north-facing slopes, 


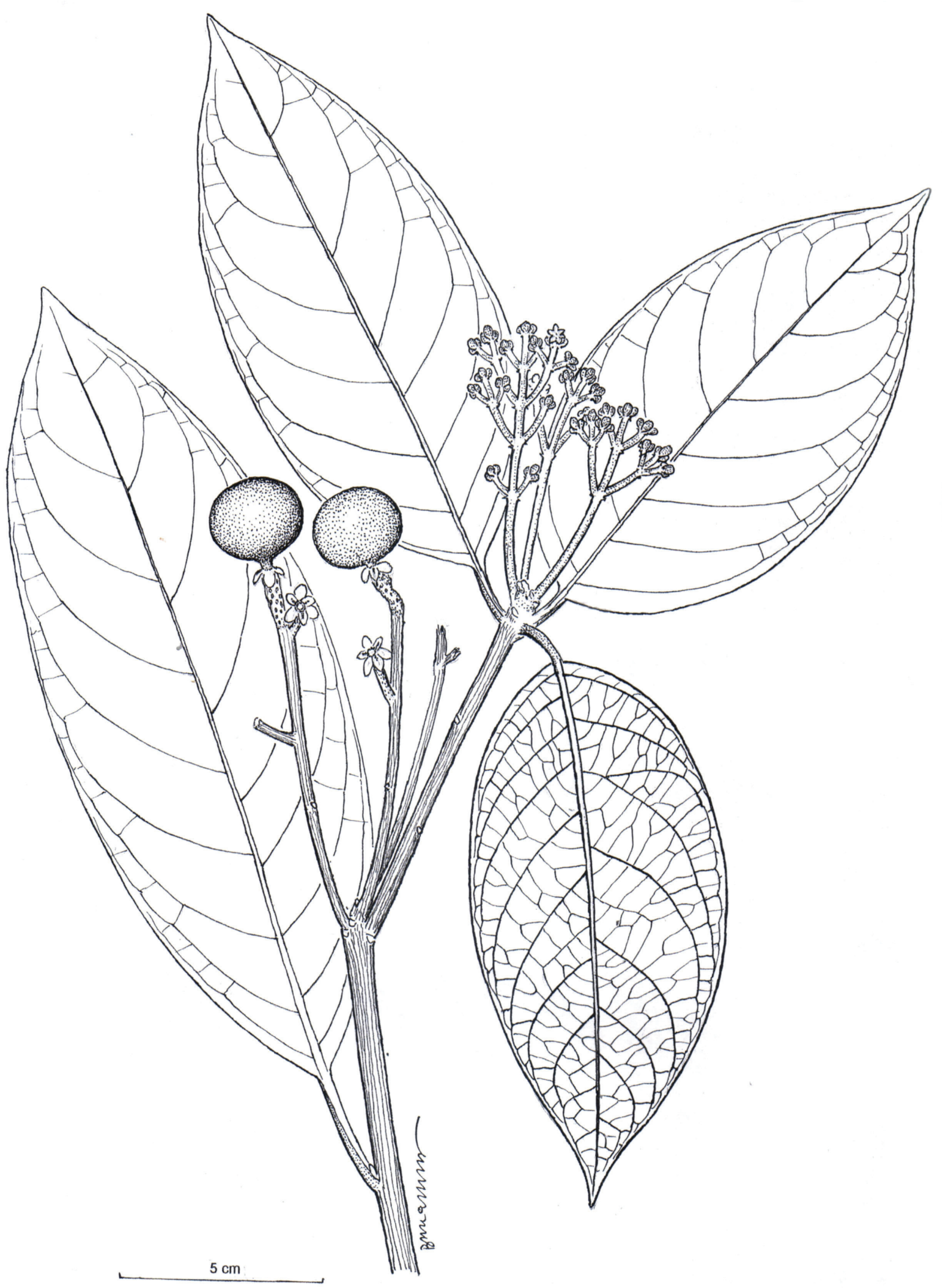

Figura 14. Persea rigens var. oblaticarpa

Figure 14. Persea rigens var. oblaticarpa 
between La Trinidad and Quebrada El Boquerón, southwest of Cocollar, 3-V-1945, J.A. Steyermark 62459 (F). Trujillo: Municipio Carache, entre Mesa Potrera y el Páramo de Cendé, 6-7-X-1995, A. Licata et al. 624 (PORT).

23. Persea ruizii J.F. Macbr., Publ. Field Mus. Nat. Hist., Bot. Ser. 11(1): 18. 1931.

= Persea ferruginea Mez, Jahrb. Königl. Bot. Gart. Berlin 5: 154. 1889.

Figura 13D.

Árbol, $8 \mathrm{~m}$ alt.; ramas con sección transversal angular, cubiertas por tricomas amarillentos, ondulados, erectos, con cobertura densa; yemas apicales cortas, con indumento igual que las ramas. Hojas distribuidas a lo largo de las ramas; pecíolos $1,9 \times 0,3 \mathrm{~mm}$, aplanados, pubescentes; láminas foliares elípticas, 10,9-11,5 × 5,2-6,0 cm, con largo:ancho igual a 2:1, ápice y base obtusa, margen ligeramente revoluto hasta la mitad de la lámina, con por tricomas amarillentos, ondulados, erectos, con cobertura medianamente densa en la cara abaxial; nervio medio más ancho en la mitad basal, convexo en la haz, glabro; venación craspedódroma, 6 pares de venas secundarias, divergentes en ángulo obtuso, curvas, ramificadas antes de alcanzar el margen, con patrón reticulado aleatorio; venación marginal fimbriada, areolas imperfectamente desarrolladas o poco visibles. Inflorescencias subterminales, hasta $10,0 \mathrm{~cm}$ long., más largas que las hojas adyacentes. Tépalos conspicuamente desiguales entre sí, los tres externos tan largos como la mitad de los internos, con tricomas amarillentos, ondulados, erectos, con cobertura densa en la cara abaxial, mientras que los internos presentan tricomas en ambas caras. Estambres fértiles 9; anteras de V1 y V2 con 4 lóculos y dehiscencia introrsa. Frutos deprimido-globosos, 16,0 $\mathrm{mm}$ diám., pedúnculos $7,0 \mathrm{~mm}$ long., gradualmente engrosados hacia el receptáculo, de textura lisa; tépalos y estambres persistentes, pubescentes.

Según Kopp (1966) y la base de datos del Missouri Botanical Garden (W3TROPICOS 2011), este taxón andino sólo ha sido colectado en Perú. Sin embargo existe una colección (Kelly \& Nic Lughadha 8910) realizada en Mérida, que fue determinada como P. ferruginea; pero una observación más detallada de los caracteres del indumento y frutos permitió establecer la entidad como $P$. ruizii.

Tiene hojas ovadas a elípticas con tricomas erectos y torcidos, principalmente sobre las venas de la superficie abaxial. Los tépalos en fructificación están completamente endurecidos, patentes, 7,0 $\mathrm{mm}$ larg. aproximadamente, sosteniendo un fruto esférico de 1,3 a $1,5 \mathrm{~cm}$ de diámetro. Pertenece a la sección Mutisaea y está emparentada con $P$. ferruginea, de la cual difiere en la forma de las hojas, el número de venas secundarias, la ausencia de retículo de venas en la cara abaxial y el tamaño de los tépalos y frutos.

Materiales examinados: VENEZUELA. MérIDA: La Montana study area, ca. $1 / 2 \mathrm{~km} \mathrm{~S}$ of La Montana Teleferico station, 12-VIII-1987, D.L. Kelly \& E.M. Nic Lughadha 8910 (VEN).

24. Persea subcordata (Ruiz \& Pav.) Nees, Linnaea 21: $492.1848 \equiv$ Laurus subcordata Ruiz \& Pav. Tipo: PERÚ. Chinchao, 1778-88, Ruiz \& Pavón s.n. (Isótipo B!).

Figuras 1F, 3E, 3F

Árbol, 5-25 m alt., 80 cm DAP; ramas con sección transversal terete o angular, cubiertas por tricomas amarillentos, rara vez ferrugíneos, ondulados, erectos con cobertura densa; yemas apicales con indumento igual que las ramas. Hojas distribuidas a lo largo de las ramas; pecíolos 2,4-4,4 × 0,23-0,40 cm, acanalados, a menudo pubescentes; láminas foliares ovadas hasta elípticas, 11,7-19,1 × 7,7-13,4 cm, con largo:ancho igual a 1:1 a 2:1, ápice obtuso, redondeado, base obtusa, ligeramente cordada hasta auriculada, margen entero, con tricomas amarillentos o ferrugíneos, ondulados, erectos con cobertura densa en la cara abaxial; nervio medio hundido en la haz, frecuentemente pubescente; venación eucamptódroma, 8-10 pares de venas secundarias, divergentes en ángulo obtuso, raras veces en ángulo recto, curvas, ramificadas antes de alcanzar el margen, anastomosadas, cerrándose por arcos secundarios formados por venas de $3^{\circ} \mathrm{y} 4^{\circ}$ orden, con patrón reticulado aleatorio; venación marginal formando lazos cerrados, areolas perfectamente desarrolladas, de forma angular, a veces con venillas simples dentro de la areola. Inflorescencias de apariencia corimbiforme, subterminales o axilares, hasta 18,0 cm long., alcanzando $1 / 2$ de la longitud de las hojas o ligeramente más largas que las hojas adyacentes. Flores 4,5-6,5 mm long., pedicelos 1,7-3,0 mm long. Tépalos conspicuamente desiguales entre sí, los tres externos tan largos como la mitad de los internos, erectos, los externos cubiertos por tricomas amarillentos, rara vez ferrugíneos, ondulados, ascendentes o adpresos, con cobertura densa en la cara abaxial, mientras que los internos presentan tricomas 
en ambas caras de los tépalos internos. Estambres fértiles 9; anteras de V1 y V2 oblongas u ovadas, 1,0-1,6 $\times$ 0,6-0,8 mm, 4 lóculos, con dehiscencia introrsa, glabras o pubescentes en la cara abaxial, filamentos hasta $2,5 \mathrm{~mm}$ long., ligeramente más largos que las anteras, pubescentes; anteras del V3 rectangulares, $0,8-1,4 \times 0,4-0,5 \mathrm{~mm}, 4$ lóculos, con dehiscencia latrorsa, glabras o pubescentes en la cara abaxial, filamentos hasta 2,2 $\mathrm{mm}$ long., a veces hasta dos veces más largos que las anteras, pubescentes, acompañados de un par de glándulas redondeadas o cordadas, sésiles, adnadas en la parte basal o a $1 / 4$ de la longitud del filamento; estaminodios 3, sagitados, hasta 1,2-2,0 mm long., pubescentes; ovario elipsoidal u obovado, 0,9-4,0 × 0,8-2,7 mm, glabro; estilo 1,4-2 mm long., más largo que el ovario. Frutos globosos, 9,6-12,5 mm diám.; pedúnculos 3,0-4,5 mm long., no engrosados, de textura lisa; tépalos y estambres persistentes, pubescentes.

Se encuentra reportada para otros países andinos como Colombia, Ecuador, Perú y Bolivia. En Venezuela, ha sido colectada mayormente en los estados andinos: Mérida, Táchira y Trujillo, pero su distribución alcanza las zonas altas del Macizo del Turimiquire en el Estado Anzoátegui, entre 1.800 y $2.500 \mathrm{msnm}$. Se sospecha su presencia en los estados Sucre y Monagas. Existe una colección realizada por el Prof. Cardozo y colaboradores en los alrededores del Topo La Mesa, Parque Nacional Rancho Grande, Estado Aragua, la cual conecta directamente la distribución de la especie en los Andes y Turimiquire. Sin embargo, este especímen no tiene registro formal en un herbario por lo que no pudo ser incluido dentro del material citado para esta publicación.

Las hojas de esta especie son anchamente elípticas, con ápice agudo a obtuso, con base cuneada, generalmente. La superficie abaxial de las hojas, ramas, flores e inflorescencias está cubierta de tricomas erectos y torcidos, de color amarillento. Las nervaduras secundarias (10-12 pares) forman un retículo conspícuo y resaltado en el envés. Los pecíolos son teretes a canaliculados, de hasta $5,0 \mathrm{~cm}$ de largo. Las inflorescencias son axilares, multifloras, de apariencia corimbosa, largamente pedunculadas, alcanzando la longitud de las hojas que las sostienen. Los frutos son globosos y los pedúnculos se engrosan durante la fructificación.

Se considera afín a $P$. bernardii dadas las características similares de indumento y distribución en Venezuela, pero pueden distinguirse porque las hojas de esta última son más estrechas, elípticas, y los tépalos externos son subiguales a los internos, mientras que en el $P$. subcordata son marcadamente desiguales.

Materiales examinados: VENEZUELA. ANZoÁTEGUI: among shrubby dwarfed growth along knife-edge crest of ridge leading to summit, Cerro Peonía (Cerro Los Pajaritos), above Santa Cruz, headwaters of Río Manantiales, east of Bergantín, 21-III-1945, J.A. Steyermark 61649 (F). MéridA: Distrito Campo Elías, entre el pueblo de San José y Capilla de San Antonio, 25-III-1967, L. Ruíz-Terán et al. 3987 (MERF). TÁCHIRA: dwarfed forest on slope below Páramo de la Negra, above La Grita, 7-VII-1944, J.A. Steyermark 57109 (VEN, F). TRUJILLO: vertiente derecha del valle del Momboy, hacia la cumbre, arriba del caserío San Pedro, entre La Puerta y Lagunita, 13-VII-1986, J. Bono 6040 (VEN).

Especie imperfectamente conocida - Persea sp. vel aff. hexanthera - Este taxón imperfectamente conocido tiene ramas glabras con yemas apicales alargadas y densamente cubiertas de tricomas amarillentos, adpresos; las hojas son glabras, ovadas a elípticas, de 12,0 a $15,0 \mathrm{~cm}$ de longitud, 10 a 12 pares de venas secundarias con ángulo de divergencia de aproximamente $80^{\circ}$, el nervio medio está hundido hasta la mitad proximal de la lámina, ápice agudo y base obtusa que se atenúa cortamente al llegar al pecíolo canaliculado de hasta $3,5 \mathrm{~cm}$ de longitud.

Sólo se conoce de unas pocas colecciones realizadas en el Parque Nacional Guaramacal (Trujillo), y se distingue como una posible especie nueva para Persea en Venezuela por sus características vegetativas. Hasta el momento, ninguno de los pliegos observados para esta localidad tiene flores ni frutos, pero podría estar relacionada con $P$. fendleri y/o $P$. hexanthera.

Materiales examinados: VENEZUELA. TrujILLo: Municipio Boconó, Parque Nacional Guaramacal, bosques bajos en las cercanías de Cerro El Diablo y Quebrada Honda, Parcela No 23, 4-VIII-2002, N. Cuello et al. 2472 (VEN, PORT); Municipio Boconó, Parque Nacional Guaramacal, bosques húmedos de la vertiente norte, parcela de estudio fitosociológico $\mathrm{N}^{\mathrm{o}}$ 16, 3-4-II-2000, N. Cuello et al. 1953 (PORT); idem Cuello et al. 1963 (PORT).

Relaciones morfológicas entre especies de Persea en Venezuela - La variación morfológica observada entre los taxones estudiados resultó crítica en la 
determinación de los mismos. Se distinguieron grupos de especies con semejanzas como $P$. ferruginea, $P$. ruizii, $P$. bernardii y $P$. subcordata, la mayoría crece frecuentemente en los bosques andinos. Estas especies comparten similitud por las características de los tricomas sobre las ramas, pecíolos, hojas y tépalos. Se identificó un complejo formado por $P$. hexanthera y $P$. meridensis que amerita mayor investigación ya que las diferencias morfológicas presentadas por Kopp (1966) y las encontradas en este trabajo no son lo suficientemente contundentes para discriminar entre ambos taxones. Hacia el sur del país, se encuentra un complejo de dos especies semejantes en las características del indumento que cubre sus hojas y flores: P. fastigiata-P. perseiphylla, donde la primera se distingue por la presencia de seis estambres fértiles y ovario glabro; mientras que $P$. perseiphylla tiene nueve estambres fértiles y ovario pubescente.

Persea americana, P. mutisii y P. caerulea son especies con amplia variabilidad en los caracteres foliares, mostrando hojas más grandes o más delgadas, glabras o con tricomas de acuerdo con el lugar donde hayan sido colectadas; sin embargo, pueden distinguirse claramente de otras especies por los caracteres reproductivos. Otras especies como $P$. povedae, $P$. fendleri, $P$. cuneata, $P$. lemensis, $P$. maguirei y $P$. rigens presentan atributos morfológicos propios que facilitan su identificación en los herbarios.

Consideraciones finales - Esta revisión taxonómica generó valiosos aportes al conocimiento de la flora venezolana, añadiendo nuevos taxones a la lista ya conocida. La implementación de herramientas como el paquete de software DELTA constituyó un avance en la homogeneidad del orden de los caracteres estudiados en las descripciones en lenguaje natural, manejo de datos de herbario, codificación de caracteres e identificación de información taxonómicamente resaltante para la determinación de especies. Adicionalmente, el patrón de distribución de las especies al norte y sur del país constituye un resultado práctico para la identificación de los taxones.

\section{Agradecimientos}

A los curadores y asistentes de los herbarios revisados, por su valiosa colaboración. Al Dr. Shingo Nozawa por el apoyo con el manejo de SIG, y al Prof. Bruno Manara por sus ilustraciones y traducciones al latín. A la Lic. Giovannina Orsini
Velásquez por ilustrar las estructuras reproductivas de la nueva variedad de $P$. fastigiata. Al Dr. Elio Sanoja por su observaciones y fotografías de $P$. lemensis. A la Fundación Instituto Botánico de Venezuela "Dr. Tobías Lasser" por el financiamiento para esta investigación, tanto como al Herbario Nacional de Venezuela por permitir el manejo de sus colecciones y otros préstamos.

\section{Literatura citada}

Allen, C.K. 1945. Studies in Lauraceae. VI. Preliminary survey of the Mexican and Central American species. Journal of the Arnold Arboretum 26: 282-434.

Bernardi, L. 1962. Lauráceas. Universidad de los Andes, Mérida.

Ferrer-Pereira, H.E. 2009. Lauraceae del Herbario Nacional de Venezuela (VEN). Acta Botanica Venezuelica 32: 237-250.

Ferrer-Pereira, H.E., Vivas-Arroyo, Y., Hokche, O., Nozawa, S., Pérez-Cortéz, S., Rodríguez, L., Mostacero, J. \& Estrada-Sánchez, J. 2010. Aplicación de herramientas computacionales al estudio morfotaxonómico del género Merremia (Convolvulaceae) en Venezuela. Rodriguésia 61: 661-668.

Heywood, A. 1993. Flowering Plants of the World. Oxford University Press, New York.

Hickey, L. 1973. Classification of the architecture of dycotyledonous leaves. American Journal of Botany 60: 17-33.

Holst, B.K. \& Todzia, C. 1990. Leon Croizat's plant collections from the Franco-Venezuelan Expedition to the headwaters of the Rio Orinoco. Annals of the Missouri Botanical Garden 77: 485-516.

Kopp, L. 1996. A taxonomic revision of the genus Persea in the western hemisphere (Perseae-Lauraceae). Memoirs of the New York Botanical Garden 14: 1-117.

Madriñán, S. 2004. Lauraceae (Avocado Family). In: Flowering Plants of the Neotropics. N. Smith, S. Mori, A. Henderson, D.W. Stevenson \& S.V. Heald (eds.). New York Botanical Garden, Princeton University Press, New York, pp. 204-206.

Mez, C. 1899. Lauraceae americanae monographice descripsit. Jahrbuch des Königlichen Botanischen Gartens und des Botanischen Museums zu Berlin 5: $1-558$.

Miller, J. 1768. The Gardener's Dictionary. 8 ed. J. \& F. Rivington, London.

Nishida, S. 1999. Revision of Beilschmiedia (Lauraceae) in the Neotropics. Annals of the Missouri Botanical Garden 86: 657-701. 
Roth, I. \& Lindorf, H. 2002. South American Medicinal Plants. Springer-Verlag, Berlin.

Tropicos.org. Missouri Botanical Garden. http://www. tropicos.org (acceso en 24.03.2011).

Van der Werff, H. \& J.G. Rohwer. 1999. Lauraceae. In: P.E. Berry, K. Yatskievych \& B.K. Holst (eds.). Flora of the Venezuelan Guayana: Eriocaulaceae-Lentibulariaceae. Missouri Botanical Garden Press, St. Louis, v.5, pp. 700-750.

Van der Werff, H. 1989a. Novelties in the Lauraceae from Venezuelan Guayana. Annals of the Missouri Botanical Garden 76: 462-475.

\section{Lista del material examinado}

Acevedo 11 (1); G. Adamo \& B. Briceño 1063 (18); G. Adamo \& J. López 1897 (4); G. Agostini 2517 (1), 438 (4); C.K. Allen \& T. Lasser 12 (4); A.B.C. Alston 5488 (1); H. Alvarado \& E. Giménez 321371 (4); H. Alvarado, C. Acosta, L. Alvarez, F. Díaz,

Hno. Antonio \& J. Hoyos 355 (4); E. Ara 11 (20); L. Aristeguieta 16 (4), 3646 (18); L. Aristeguieta \& E. Medina 36463660 (18); A. Artigas \& M. Gudiño 10 (1); M. Ataroff 87 (24); G. Aymard, H. van der Werff \& N. Cuello $5174(10)$.

V. Badillo 8571727 (4) 34655314 (18); V. Badillo, C.E. Benitez de Rojas \& T. Ruíz 7963 (18); F. Bascopé 17 (1); J. Bautista 43 (1) 3813 (4) 3615 (10); M.T. Belandria 67 (1); A.L. Bernardi 6450 (3), 393 4477434 (4), 10958 (10), 5728 (13), 1311644410957 10959 s.n. (US79183) (18), 6063 (24); P.E. Berry 4093 (4); P. Berry, R. Duno \& G. Romero 56185645 (11); J. Bono 6040 (23); B.M. Boom \& A.L. Weitzman 5743 (19), 5405 (21); F.J. Breteler 4501 (4); B. Briceño \& G. Adamo 1849 (4) 2407 (18); W.E. Broadway 640 (1); G. Bunting \& F. Arboleda 8731 (1); G. Bunting, L.M.A. Akkermans \& J. van Rooden 40414050 (11).

P. Cabeza 85 (1); O. Camacaro 90 (4); L. Cárdenas 872 (18); L. Cárdenas \& G. Cárdenas 4018 (4); F. Cardona 4352 (18); A. Cardozo \& grupo de taxonomía de campo 923 (4); A. Cardozo \& X. Bastardo 2175 (13); A. Cardozo, D. Conde, L. Peña \& R. Luján 2838 (4); A. Cardozo, L. Lemus \& R. Wingfield 47 (1); G. Carnevali, R. Liesner \& G. Santana 2565 (19); V. Carreño Espinoza s.n. (VEN142717) (4); J.A. Casadiego 250 (4); J. Cavelier 2 (10); A. Charpin \& F. Jacquemoud AC13507 (18); A. Chaviel 409414 (12), 182 (14); M. Cifuentes \& H. Cabrera 21 (4); D. Conde et al. 160 (13); T. Croat 59519 (5); L. Croizat 918 (6); N. Cuello 2434 (17); N. Cuello, A. Henríquez, A. Henríquez \& E. Cuello 1770 (22); N. Cuello, A. Licata, B. Milano \& C. Oráa 943 (17); N. Cuello, A. Licata, J. Farreras, P. Tovar \& R. González 1985 (17),
Van der Werff, H. 1989b. A new species of Persea (Lauraceae) from Surinam, with a discussion of its position within the genus. Annals of the Missouri Botanical Garden 76: 939-941.

Van der Werff, H. 2002. A synopsis of Persea (Lauraceae) in Central America. Novon 12: 575-586.

Van der Werff, H. 2008. Lauraceae. In: O. Hokche, P.E. Berry \& O. Huber (eds.). Nuevo Catálogo de la Flora de Venezuela. Fundación Instituto Botánico de Venezuela, Caracas, pp. 428-435.

19531963 (25); N. Cuello, B. Stergios, N. Niño, P. Tovar \& E Cuello 189218851897 (17); N. Cuello, K. Bastidas, L. Linares \& K. Tovar 2668 (17); N. Cuello, O. León, R. Caracas, K. Bastidas, L. Linares \& P. Tovar 2472 (25); L.J. Cumana Campos 94 (1).

G. Davidse 27717 (11); G. Davidse \& A. González 19628 (18); F. Delascio \& L.M. de Delascio 13899 (1); F. Delascio \& R. Liesner 13476 (19); F. Delascio \& R. López 12843 (1); L.J. Dorr \& L.C. Barnett 5130 (10), 5140 (18); L.J. Dorr, L.C. Barnett \& M. Guerrero 5750 (18); L.J. Dorr, L.C. Barnett \& R. Rivero 5494 (10); L.J. Dorr, L.C. Barnett \& R. Rosales 74947500 (18); L.J. Dorr, L.C. Barnett, G. Aymard \& N. Cuello 5357 (4); L.J. Dorr, S.M. Niño \& R. Caracas 8983 (10); R. Duno \& R. Riina 1473 (10), 1376 (15); R. Duno, R. Riina, W. Meier \& col. 1076 (10).

K.S. Edwards, T. Roe \& R. Thompson 369 (1); Eggers 1308113334 (4); A. Espinoza 16 (1).

P. R. Felipe E. 2 (4); A. Fendler 171 (1), 172 (4), 1096 (9); G. Ferrari 228 (1), 1521 (4); H. Ferrer-Pereira 70 (1), 115 (4); H. Ferrer-Pereira \& S. Romero 431 (1), 421 (4), 425426 (17), 434 (24); H. Ferrer-Pereira, E. Sanoja, O. Hokche, Y. Vivas \& F. Salazar 579 (8a) 605606 (15); H. Ferrer-Pereira, I. Fedón \& I. Vera 269274 (4); H. Ferrer-Pereira, J.J. Mucherino \& S. Romero 331414 (1), 418 (4); W. Flores 5 (1); E. Foldats 7090 (8a).

Gehriger 554 (4); A. Gentry \& B. Stein 46632 46754 (21); A. Gentry, G. Rodrigues \& R. Sinchi 41278 (4); H. Gil Figueiras 56 (4); Hno. Ginés 990 (1); Hno. Ginés \& L. Ninín s.n. (CAR-697) (4); F. Guánchez 809 (12).

L. Hernández VI (1); B.K. Holst \& R. L. Liesner 3297 (8a), 3419 (21); Hooker 307 (1); J. Hoyos 21802201 (4); O. Huber 12227 (8a); A. Huizzi C. H-19 (1).

Ijjasz 266 (4), 288 (18)

A. Jahn 1066 (18); O. Jiménez s.n. (VEN30237) (18); E. Jimenez, A. Cardozo \& A. Alarcón 2 (4); E. 
Jimenez, A. Cardozo, D. Conde \& L. Moreno 217 (4); E. Jimenez, A. Cardozo, L. Moreno \& R. Ecarri 295 (4) D.L. Kelly \& E.M. Nic Lughadha 8910 (23)

A. Lárez, A. de Brown \& R. González 7281 (1), 7699 (4); T. Lasser 664 (1), 6486260 (4), 1206 (17), 2454 (18); T. Lasser \& C.K. Allen 4399 (4); R. Liesner 13609 (1), 16038 (8c), 1776018083 251172513125885 (8a), 18521 (8c); R. Liesner \& F. Delascio 2209922169 (19); E.L. Little Jr. 15338 (1), 1525215257152911590616051 (4), 15388 (18); M. López-Figueiras \& H. Rodríguez 9069 (4); S. López-Palacios 2051352 (4), 571069 (18); S. López-Palacios \& J.A. Bautista-Bautista 3537 (1); J. Luteyn \& M. Lebrón-Luteyn 9782 (18); J. Luteyn, M. Lebrón-Luteyn \& L. Ruiz-Terán. 6051 (18); J. Luteyn, S. Mori, N. Holmgren \& J. Steyermark 8326 (9); P.J.M. Maas \& V. Badillo 2173 (1).

G. Macuar 15 (1), 22 (4); B. Maguire, R.S. Cowan \& J.J. Wurdack 29874300193013030199 (8a), 29599 (17); B. Maguire, J. Steyermark \& C. Maguire 46843 (8a); B. Maguire, J.J. Wurdack \& C.K. Maguire 4208542572 (2), 42497 (8a), 4219142557 (12), B. Maguire, J.J. Wurdack \& G.S. Bunting 36958 (8a); B. Manara s.n. (VEN115760-VEN115762) (4), s.n. (VEN318174) (18); L. Marcano-Berti 840959 (4); L. Marcano-Berti \& S. López P. 1730 (17); F. Matos BAIL-44 FM-1130 (4), BAIL-20(18); E. Mavarel 4 (1); W. Meier 85 (4); W. Meier \& G. Bronner 35633564 (18); W. Meier \& O. Kunert 4762 (1); W. Meier \& P. Borjas 5975 (1); W. Meier, R. Riina \& R. Duno 6306 (10); F. Mejía 5 (1); C. Mercado 2 (1); Mocquerys 1110 (4); B. Mora C. 18 (1); G. Morillo 2185 (4); G. Morillo $\&$ N. Morillo 2211 (1).

M. Navas \& C. Troconis 13 (1); M. Nee 17124 (1); S. Nilsson \& J. Steyermark 120331 (14); S.M. Niño 115 (7), 356(17); S.M. Niño, J. Farreras \& B. Stergios 114 (17).

B. \& F. Oberwinkler 15140 (4); F. Oberwinkler 15605 (1); F. Ortega, L. Marcano, W. Hidalgo \& I. F. Pannier $216(4)$.

Peña 3200 (18); G. Picón, A. Briceño \& S. Matezki 2746 (8a); J.J. Pipoly 6444 (18); H. Pittier 59137772 785892131016012854 (1) 710678621033412397 1367615777 (4) 7541 (15); R.A. Pursell, Ch.L. Curry \& P.R. Kremer 8882 (4).

G. Queipo 10 (1); R. Quero 5 (1); A. Quintero 136 (1), 122132150 (4), 1400 (18); A. Quintero \&
P. Salcedo 1333 (4), 1432 (18); R.D. Quintero \& C. Hernández 257 (4).

M. Rengifo 11 (1); M. Ricardi 7135780 (4); M. Ricardi \& P. Salcedo 5758 (4); M. Ricardi \& R. Carroz 46 (18); R. Rico 492506 (4); R. Riina, R. Duno, R. Ghinaglia \& R. Gonto 726 (10); R. Riina, W. Meier \& R. Duno 895 915 (10); E. Rivero 6 (1); H. Rodríguez 6633668 (1); H. Rodríguez \& H. Durán 1150 (4); M. de Rodríguez M0107 (18); Mr. \& Mrs J.N. Rose 21714 (1); L. Ruiz-Terán 7313135 (4), 10027242903113379 (18), 1421 (20); L. Ruíz-Terán \& A. Usubillaga 13496 (4); L. Ruíz-Terán \& J.A. Dugarte 16336 (1)12340 15782 (18); L. Ruíz-Terán \& L. Ruiz-Pérez 13786 (1); L. Ruiz-Terán \& M. López Figueiras 1979 (4), 903940 2005 (10), 4641197213874929403 (18), 7647 (24); L. Ruíz-Terán, J. Luteyn \& M. Lebron 16058 (18); L. Ruíz-Terán, J.A. Dugarte \& M. López-Figueiras 14363 (18); L. Ruíz-Terán, M. López-Figueiras \& S. López-Palacios 3905 (19), 3987 (24); L. Ruiz-Terán, S. López-Palacios \& J.A. Dugarte 1458015447 (4); T. Ruiz Z. \& Equipo de Ecología 2835 (13).

P. Salcedo 34 (1); E. Sanoja, L. Hernández \& L. Salazar 7893 (14); M. Santiago, J. Fermin \& M.A. Méndez MSJF166 (1); L. Schnee 1249 (1), 1335 (4); Sierra M., Rafael A. \& Uzcátegui, P. Joseph G. 10 (1); R.F. Smith V1543-V1545 V4108 V8574 (4), V3260 V3261 (20); Standen 18 (4); L.E. Skog 1245 (4); B. Stergios 17620 (10); B. Stergios \& A. Licata 19177 a (17); B. Stergios, N. Cuello \& P. Berry 17066 (17); J. Steyermark 92141 (1), 5595761786104772 (4), 104629 (7), 59898599097544794053 (8a), 59814 (8c), 91412 (9), 58259604936071393567 (14), 616196209262598105095 (18), 613076198962459 (22), 5710961649 (24); J. Steyermark \& P. Berry 112064 (4); J. Steyermark \& V. Carreño E. 111651 (4); J. Steyermark \& B. Holst 130666 (8a), 130622 (12); J. Steyermark \& R. Liesner 121837 (4); J. Steyermark \& B. Manara 125353 (18); J. Steyermark \& S. Nilsson 757 (15); J. Steyermark \& J. Wurdack 1240 (8a); J. Steyermark, A. Bruzual, E. Mondolfi \& J.M. Cabrera 114044 (4); J. Steyermark, B. Maguire, C. BrewerCarías \& V. Carreño E. 124078 (15); J. Steyermark, G.C.K. \& E. Dunsterville 105659105771 (4), 92374 92485 (14), 104427 (15), 98770101233 (18); J. Steyermark, V. Carreño Espinoza \& Ch. BrewerCarías 109578 (8a), 109165 (12), 109165109498 109688 (14); J.A. Suárez 4 (1); A. Sugden 1138 (4).

F. Tamayo 2433 (4), 3071 (14), 2392 (18); G.H.H. Tate 773 (14); N.E. Torres 3 (4); F. Torres \& J. Gaviria 7 
(18); B. Trujillo 9911692 (4); B. Trujillo \& O. del Castillo 8312 (18); B. Trujillo, D. Rojas de Trujillo \& M. Trujillo 17817 (4)

H. van der Werff 3683 (13); H. van der Werff \& F. Ortega 8191 (18); H. van der Werff, B. Stergios, $R$. Rivero, F. Ortega \& G. Aymard 7621 (17); L. Valverde 120 (4); V. Vareschi 6353 (4), 5622 (18); M. de Vásquez 8377 (4); J. Velazco 1901 (11); P. Vit-Olivier \& S. López-Palacios 44133 (1); C. Vogl 379 (4).
H.N. Whitford 37 (4); C.W. Wood 431 (1); L. Williams 1003010212 (4), 14122 (11); R. Wingfield 7514 (1), 5775 (4) 129431369313694 (13); R. Wingfield \& B. Rollet 8261 (13); R. Wingfield, A. Cardozo \& M. Arends 7863 (4); J.J. Wurdack \& J. Steyermark 451 (8a).

N. Xena, M. López \& R. Madriz 1197 (4)

O. Zambrano \& L. Alfonzo 1489 (4); S. Zent 68507 (1) 